\title{
Environmental radioactivity studies in Kabul and northern Afghanistan
}

\author{
Von der Fakultät für Mathematik und Physik \\ der Gottfried Wilhelm Leibniz Universität Hannover \\ zur Erlangung des akademischen Grades \\ Dr. rer. nat \\ genehmigte Dissertation
}

Von

M. Sc. Mohammad Rahmatullah Tanha 
Vorsitzender:

1. Referent:

2. Referent:

3. Referent:

Tag der Promotion: $\quad 30.11 .2017$
Prof. Dr. Gunnar Friege

Prof. Dr. Gunnar Friege

Prof. Dr. Clemens Walther

Prof. Dr. Georg Steinhauser 
Dedicated to

My parents, family and friends for their love, support and encouragement 


\section{Declaration of authorship}

I confirm that this thesis is the result of my own original work which is not presented to any other entity or institution for obtaining any degree or recognition before. The reference for any external quotation and source is given in the text and at the end of the thesis. The work done in collaboration with other entities and institutions is acknowledged in the text body. This work contains 122 Pages including 1 cover, 1 defense information, 1 dedication, 1 authorship declaration and 1 acknowledgements pages.

Date and place

Mohammad Rahmatullah Tanha 


\section{Acknowledgements}

First and foremost I offer my sincerest gratitude to my supervisor Prof.Dr.Clemens Walther who has supported me throughout my research work with his patience, friendliness and ocean of knowledge. Without his encouragement and effort this thesis would not have been completed or written at any time soon or later.

I am grateful of Dr. Beate Riebe, Dr. Stefan Bister and Dr. Frank Tawussi who had extremely helped me carrying out this work. They both put too much effort together in order to encourage me treating complicated problems in a simple ways. I thank Prof. Dr. Georg Steinhauser, Dr. Jan-Willem Vahlbruch, Dr. Michael Täschner, Dr. Michael Steppert, Dr. Claudia Fournier, Dr. Elena L. Mühr-Ebert, Stephanie Schneider, Linda Hamann, Alex Hölzer, Fabian Köhler, Claudia König, Wolfgang Schulz, Hauke Bosco, Martin Weiß, Hilal Alemdar, Sebastian Büchner, Ralf Groffmann, Karl-Heinz Iwannek and all IRS staff members from scientific personals to organizational and technical staff who have helped me and provided me with useful and demanded information in time.

It goes without saying to thank Prof. Dr. Abdulhai Nazifi, Abdulghafar Niazai, Fazalrahman Khalid and Abubaker Storai for helping me in sample collection and supported me throughout the whole scientific work.

Special thanks go to Prof. Dr. Claus Grupen who simply enabled me to study and work in German academic environment and Prof. Zalmai Ahmadzai who encouraged and guided me throughout my whole academic career.

At the end I am gratefully thankful of the Siebold Sasse Stiftung for the financial support of my studies, without their help and support, none the task would be possible to carry out. 


\section{Kurzzusammenfassung}

Während der Sowjet-Ära wurde von mehreren Orten der Randbezirke von Kabul (Afghanistan) berichtet, an denen ein erhöhtes Level an Umweltradioaktivität gefunden worden war. Heutzutage sind diese Gegenden mit Wohnhäusern überbaut. Im Rahmen dieser Arbeit wurden von diesen Orten in drei Probenahmekampagnen, insgesamt 51 Boden- und Gesteinsproben, sowie 51 Wasserproben (zur universellen Nutzung durch die Anwohner) genommen und der Gehalt an primordialen Isotopen und Tochternukliden der entsprechenden Zerfallsketten gemessen, sowie Rückschlüsse auf eine mögliche anthropogene Kontamination gezogen. Für die Analyse der Gesteins- und Bodenproben wurde primär die Gamma-Spektroskopie eingesetzt. Die Analyse der Wasserproben geschah vornehmlich durch ICP-MS und ICP-OES-Techniken. Des Weiteren wurden Alpha-Spektroskopie, $\mu$-XRD, PXRD, TOF-SIMS und LSC-Techniken verwendet um die Daten aus den Untersuchungen mittels Gammaspektroskopie und ICP-MS zu verifizieren. Die Aktivitätskonzentrationen in Boden und Gestein lagen, für Uran, Thorium und Kalium jeweils in den Bereichen von 160 bis 28600 Bq/kg, 73 bis 383000 $\mathrm{Bq} / \mathrm{kg}$ und 270 bis $24600 \mathrm{~Bq} / \mathrm{kg}$. Die Gesamtheit der Messmethoden zeigte keinerlei Auffälligkeit der untersuchten Proben in Bezug auf das natürliche Gleichgewicht der Radionuklide, sondern zeigte dass die erhöhte Radioaktivität auf thoriumhaltige Cheralitminerale zurückzuführen war. Die Konzentrationen von Uran und Thorium im Wasser reichten jeweils von 0,01 ppb bis $26 \mathrm{ppb}$, sowie von $2 \mathrm{ppb}$ bis $150 \mathrm{ppb}$. Es wurden keine erhöhten Gehalte an Blei und Radium im Wasser detektiert. Der Großteil der untersuchten Wasserproben ist für den Verzehr unbedenklich, einige Proben wiesen jedoch Elementkonzentrationen oberhalb der, von nationalen und internationalen Behörden empfohlenen Werte auf. Um das Gefährdungspotential durch erhöhte Umgebungsstrahlung in den Wohnräumen näher zu untersuchen, wurde die Radon-Gas Konzentration in acht Kellern, vier Wohnzimmern und vier bewohnten Höhlen an verschiedenen Orten in Kabul und Panjsher, Afghanistan, mit Hilfe acht neu entwickelter Radon-Expositions-Messgeräte, des Helmholtz-Zentrums München, gemessen. Die Messungen fanden in zwei Phasen, von je einer Woche, sowie einem Jahr Messzeit statt. In der ersten - einwöchigen - Phase lagen die durchschnittlichen Aktivitätskonzentrationen zwischen 6 und $120 \mathrm{~Bq} / \mathrm{m}^{3}$ in den Kellerräumen, sowie zwischen 25 und $139 \mathrm{~Bq} / \mathrm{m}^{3}$ in den Höhlen. In der Zweiten - ein Jahr dauernden - Phase 
der Messungen lagen die durchschnittlichen Aktivitätskonzentrationen zwischen 33 und $2064 \mathrm{~Bq} / \mathrm{m}^{3}$ and die daraus berechnete effektive jährliche Dosis für die Bewohner lag zwischen 0,6 und 33,4 mSv. Für einige Standorte ist die erwartete Dosis damit recht hoch und übersteigt die Empfehlungen von IAEA und ICRP, weshalb im Anschluss eine Reihe von einfach umsetzbaren Empfehlungen gegeben werden, wie, unter Berücksichtigung der Lebenssituation vor Ort, die jährliche effektive Dosisbelastung durch Radon reduziert werden kann.

Schlüsselwörter: Umweltradioaktivität, Radon, Afghanistan 


\begin{abstract}
Enhanced environmental radioactivity was reported for some spots of the Kabul suburbs during the Soviet era. As residential houses have been built in these places, 51 soil and rock samples as well as 51 all-purpose water samples were collected in three phases and measured in order to quantify the primordial isotopes and daughter nuclides of the respective decay chains and possible contamination by manmade radionuclides. For the rocks and soil samples gamma spectroscopy was used as main technique, while ICP-MS and ICP-OES were used as main technique for water analysis. Furthermore, alpha spectroscopy, $\mu$-XRF, PXRD, TOF-SIMS and LSC were used to verify the gamma spectroscopy and ICP-MS results. Activity concentrations in soil and rocks ranged between 160 to $28600 \mathrm{~Bq} / \mathrm{kg}, 73$ to $383000 \mathrm{~Bq} / \mathrm{kg}$, and 270 to $24600 \mathrm{~Bq} / \mathrm{kg}$ for uranium, thorium, and potassium, respectively, all measurement methods did not indicate any anomalies and identified the samples as samples high in natural radioactivity exhibiting a thorium containing cheralite mineral structure. Uranium and thorium concentrations in waters ranged from $0.01 \mathrm{ppb}$ to $26 \mathrm{ppb}$ and from $2 \mathrm{ppb}$ to $150 \mathrm{ppb}$, respectively, no considerable amounts of lead and radium were detected. Most of the investigated waters are safe to drink, some exhibit element concentrations exceeding the national and international recommended values. To assess the level of hazardousness imposed by the enhanced activity in the living spaces further, radon gas concentrations in eight basements, four living rooms and four caves from different locations in Kabul and Panjsher, Afghanistan, were measured using eight active radon exposure meters recently developed by the Helmholtz Centre in Munich, Germany. The two-phase measurements lasted from a week to a year. In the first phase of measurements which lasted one week, the mean activity concentrations ranged from 6 to $120 \mathrm{~Bq} / \mathrm{m} 3$ and 25 to $139 \mathrm{~Bq} / \mathrm{m} 3$ for the basements and caves, respectively. In the second phase of measurements which lasted one year, the mean activity concentrations ranged from 33 to $2064 \mathrm{~Bq} / \mathrm{m} 3$ and the corresponding effective annual doses calculated for the inhabitants were in the range between 0.6 and $33.4 \mathrm{mSv}$. As some of the values are rather high and exceed the recommendations by IAEA and ICRP, based on the local conditions a number of simple recommendations has been proposed for the possible reduction of effective annual dose caused by radon in the measurement locations.
\end{abstract}

Keywords: Environmental radioactivity, Radon, Afghanistan 


\section{Table of Contents}

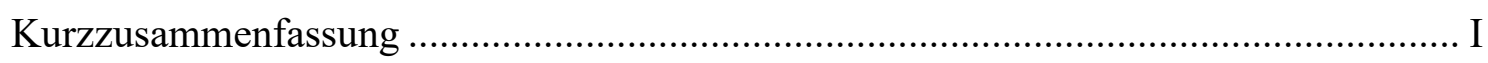

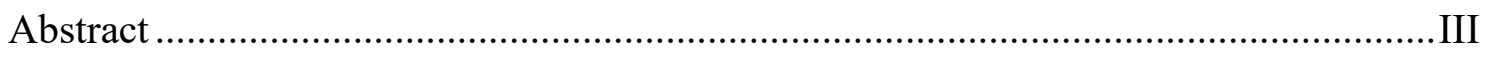

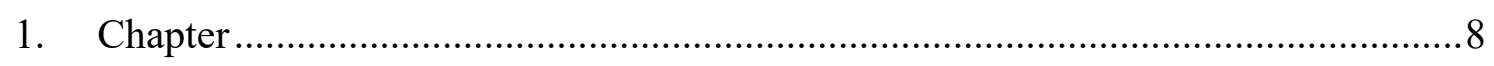

$1.1 \quad$ Motivation and chronology ...........................................................................

1.2 Environmental Sources of Radiation ................................................................11

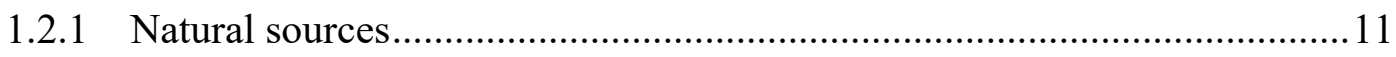

1.2.1.1 Primordial radionuclides .....................................................................

1.2.1.2 Radiogenic radionuclides ..................................................................

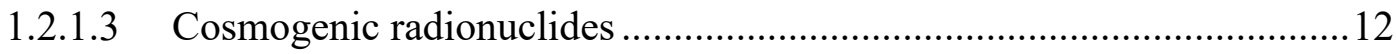

1.2.1.4 Radioactive decay and decay chains ......................................................12

1.2.2 Man-made radionuclides.......................................................................... 14

1.3 Environmental Sources of Radiation ………………………………………..... 15

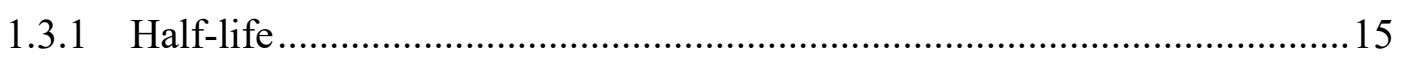

1.4 Law of radioactive decay, equilibrium and dose ............................................ 16

1.4.1 Law of radioactive decay ..........................................................................

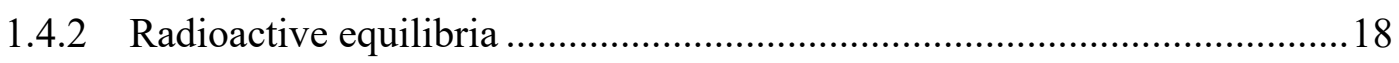

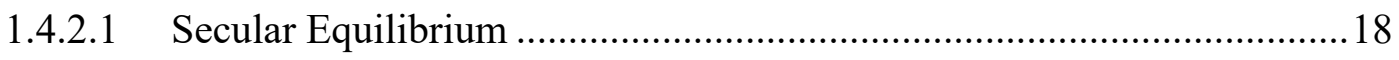

1.4.2.2 Transient Equilibrium ........................................................................2.

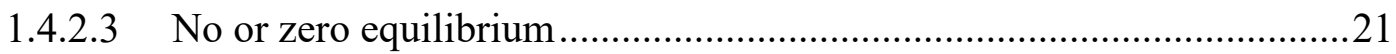

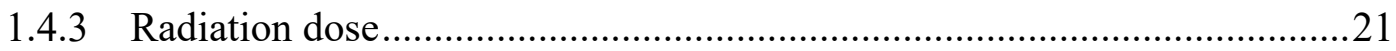

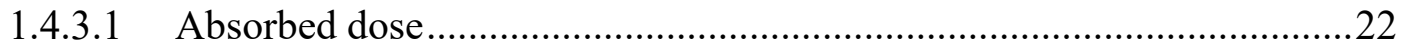

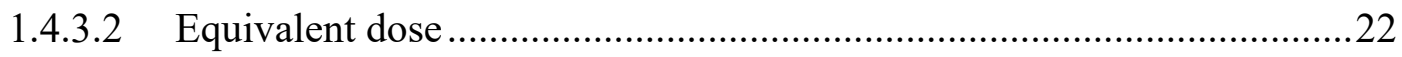

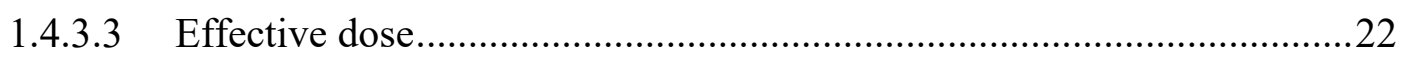

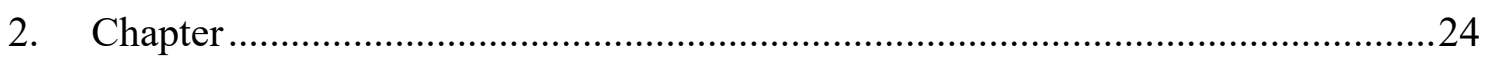

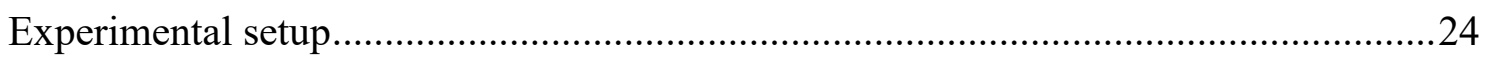


2.1 Gamma ray interaction with matter ........................................................24

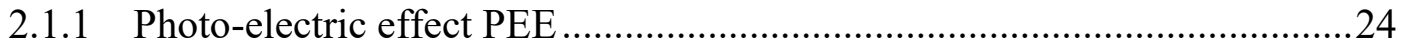

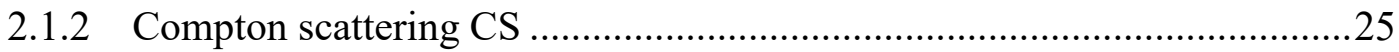

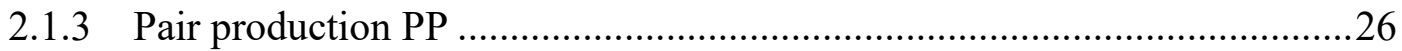

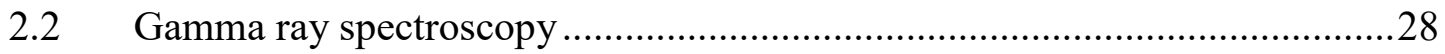

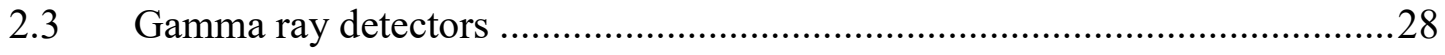

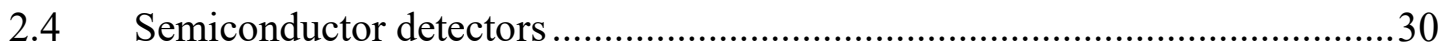

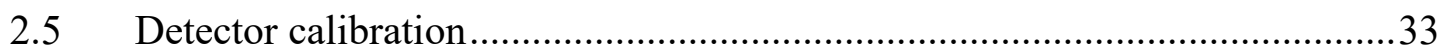

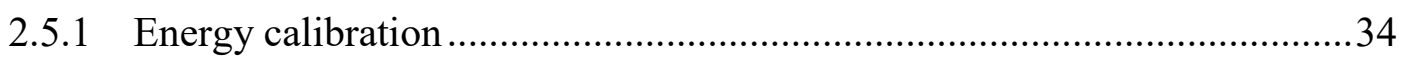

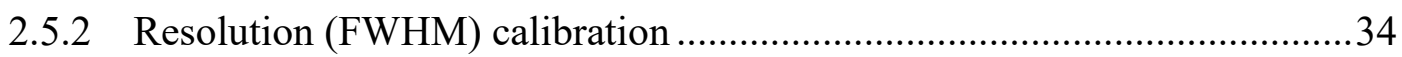

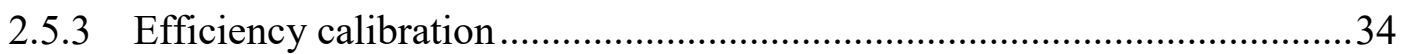

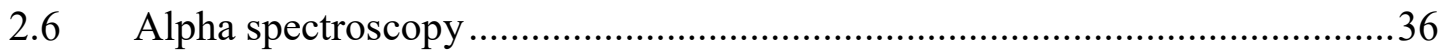

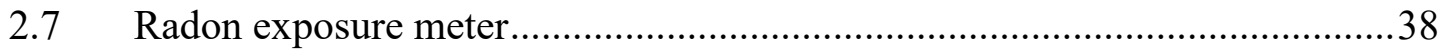

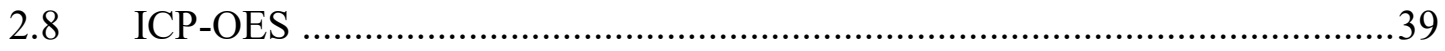

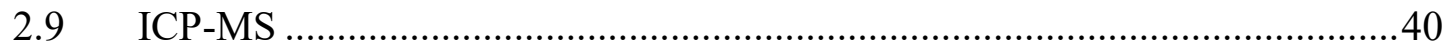

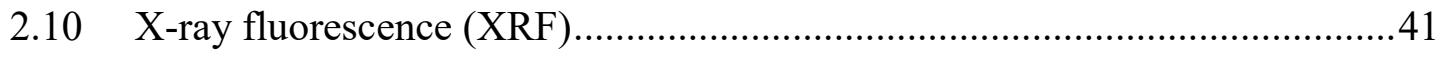

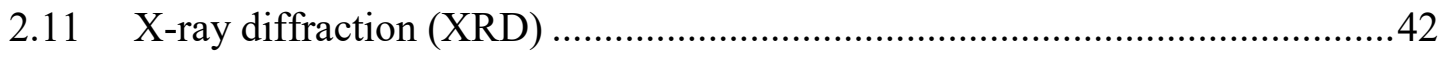

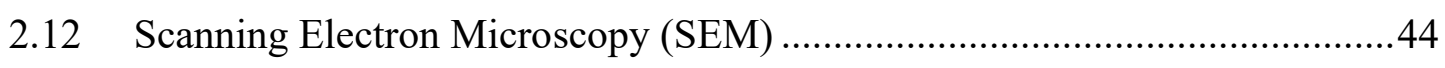

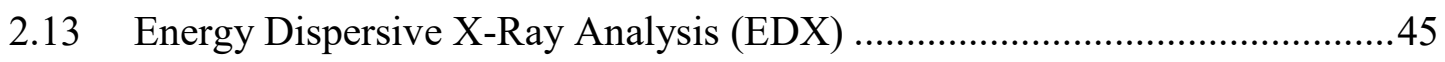

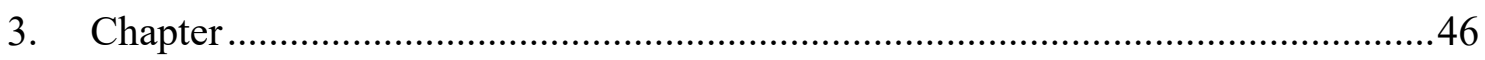

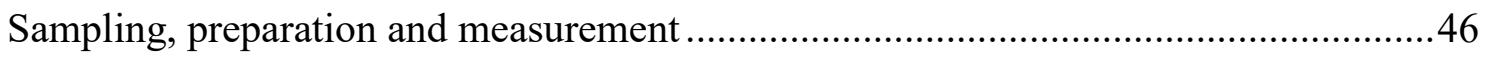

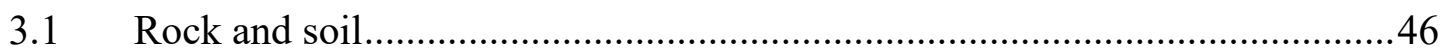

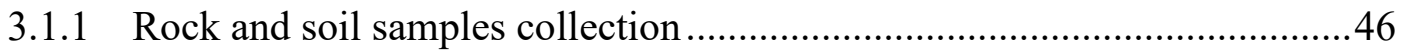

3.1.2 Sample preparation and measurement …............................................52

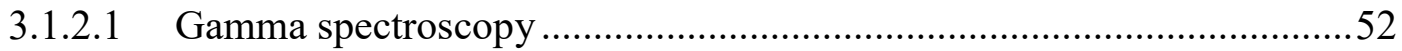

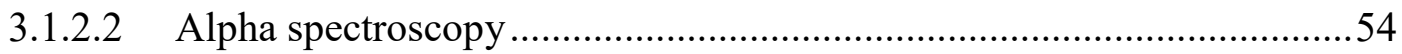




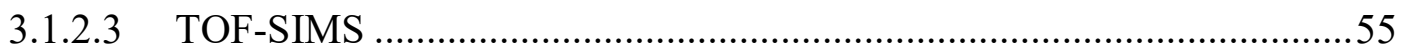

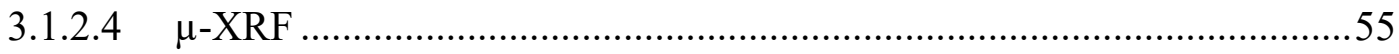

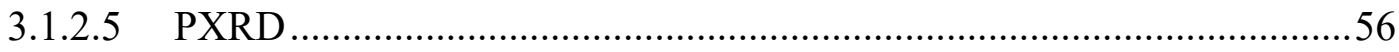

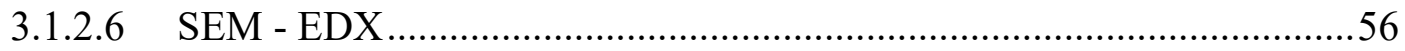

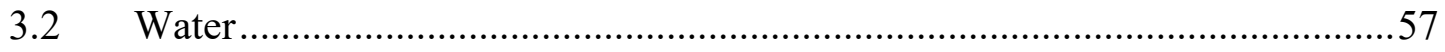

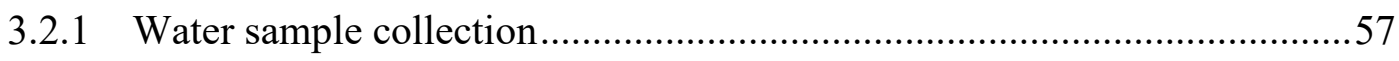

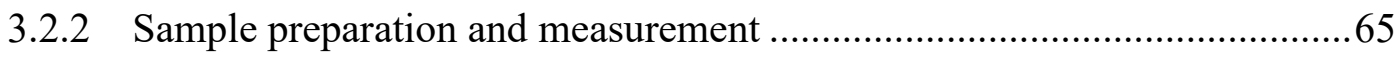

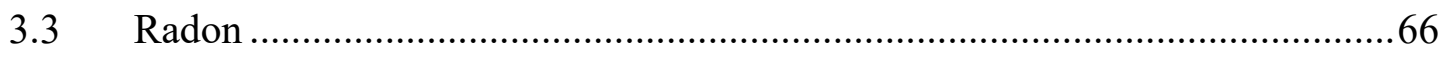

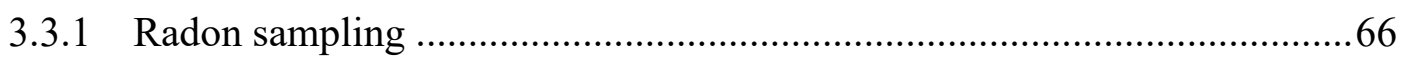

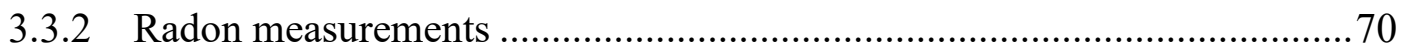

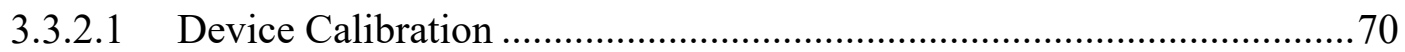

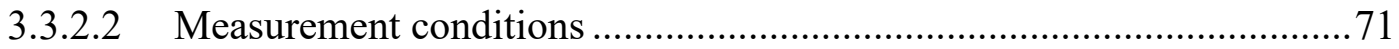

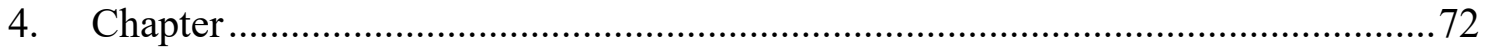

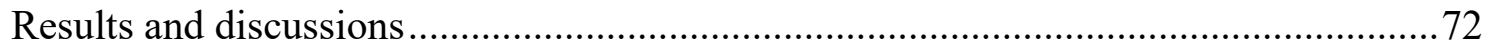

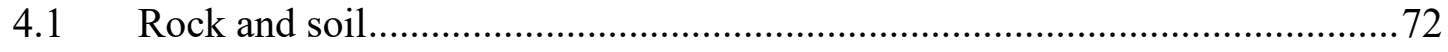

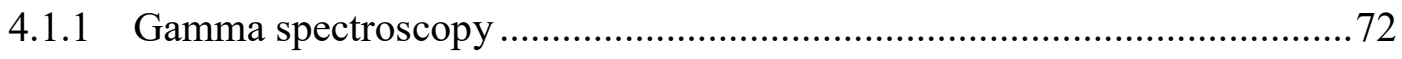

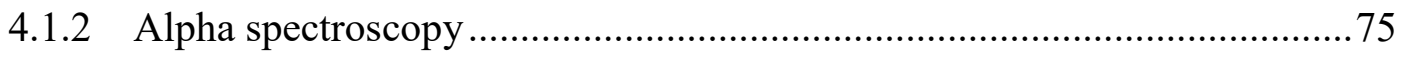

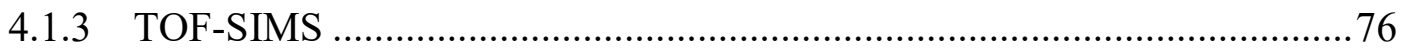

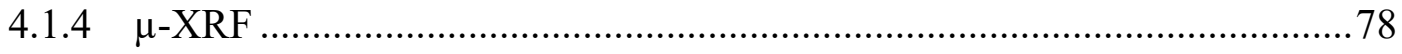

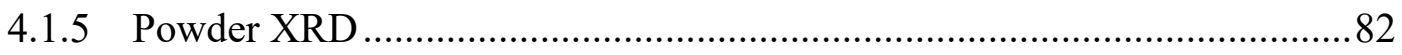

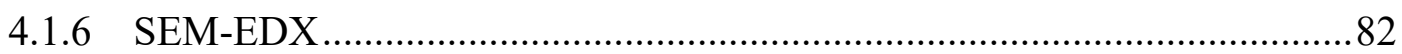

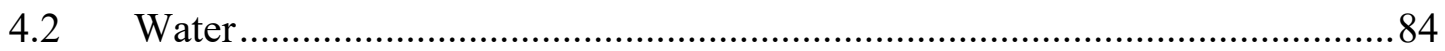

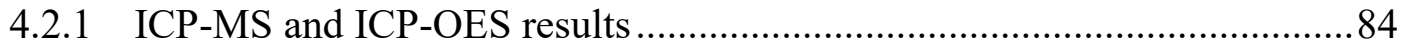

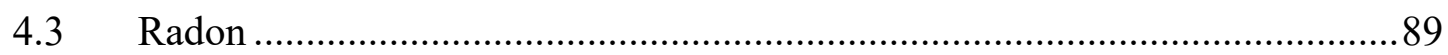

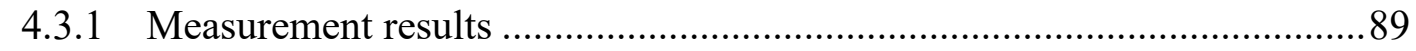

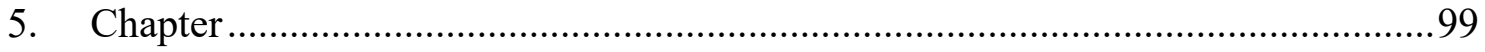


Conclusions and final remarks.....

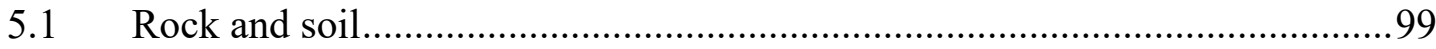

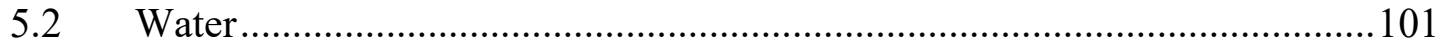

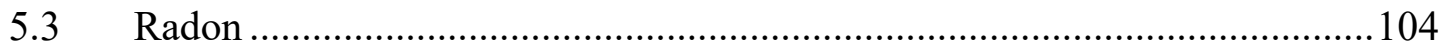

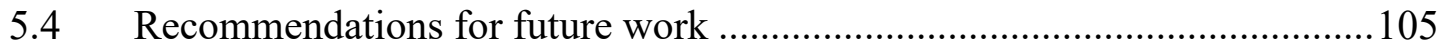

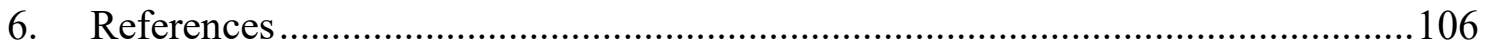

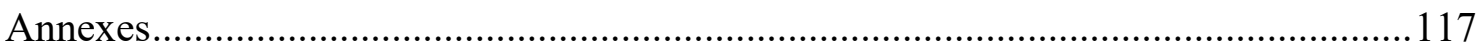




\section{Chapter}

\section{Introduction and theory}

\subsection{Motivation and chronology}

As a landlocked country one third of Afghanistan is covered by mountains where only $12 \%$ of the land is arable (World Bank, 2014). Archaeological studies show that first human beings were living 50000 years ago in a territorial landscape now called Afghanistan (Dupree, 1970). Right from the beginning, the country had the problem of providing enough flat land for housing and agriculture, thus some citizens of this territory used available flat land for cultivation and livestock farming, while hills were frequently excavated for constructing caves used as living spaces. Up to 1400 caves not easily to access were constructed in the mountains, hills and highlands of the Afghan provinces of Nangarhar, Aybak and Bamyan by Buddhist monks between the $2^{\text {nd }}$ and $7^{\text {th }}$ century for retreat and meditation purposes (Higuchi \& Barnes, 1995). The United States Survey and Geology USGS report that Afghanistan is rich with unexploited mineral resources (Chin, 2012). Thus, some technologically enhanced caves were constructed recently for illegal mining, which now are used as housing by the poor citizens of the area. Other caves different in size were constructed during war time used as hiding shelters by guerrilla fighters, who were fighting the post-soviet troops in Afghanistan (Grau \& Jalali, 2001). The latest caves were constructed used as hideouts by Al Qaeda fighters during the 2001 "Operation Enduring Freedom" coalition forces military campaign (Matthew Forney, 2011). Some of these caves were recently converted to heritage sites by the Ministry of Information and Cultural Affairs. As the caves were built in rocks, high concentration of radionuclides as well as high doses of radioactivity from rocks and indoor radon gas are expected (WHO, 2002).

Gamma radiation emitted by radionuclides from naturally occurring radioactive material (NORM), such as uranium and thorium and the products of their decay chains as well as potassium are external sources of radiation. Inhalation and ingestion of these radionuclides may lead to an internal dose. The level of radioactivity from NORM depends on geological conditions and geographical locations (UNSCEAR, 2000). NORM can be found in water, food, soil, rocks, concrete, and other building materials in considerable 
amounts. The origin of natural radioactivity in rocks and building material is the earth's crust, while the soils' radioactivity often originates from soil minerals as well as the extensive use of phosphorus rich fertilizers in agriculture (Ghosh et al., 2008).

As the basic and the most important source for life, water constitutes up to $75 \%$ of the human body weight (Schloerb et al., 1950). Two-thirds of our planet consists of water, only $2.5 \%$ of which is fresh water. Only $0.3 \%$ of this water is usable and drinkable for human beings (Schneider et al., 2011). This overall usable water is provided by surface and ground water sources. As ground water passes through rocks and soils, it takes up mineral compounds and amongst them radioactive substances due to leaching or alpha recoil (Dinh Chau et al., 2011). Meanwhile, pollution is considered a major reason for the change in composition and quality of water (United Nations, 2009). Different water sources can contain a variety of radionuclides and different levels of radioactivity. Increasing pollution with radioactive contaminants poses health problems to the consumers. Thus it is important to determine the concentration of toxic elements or radiotoxic isotopes in different sources of drinking water (Fawell, 2003). The radioactivity in water is a result of erosion and dissolution processes of rocks and minerals in the aquifers (Nuccetelli et al., 2012). Further sources of radioactivity in nature are releases from installations of the nuclear fuel cycle, technically enhanced natural occurring radioactive material (NORM), use and tests of nuclear weapons, mineral extraction facilities, and fallout from nuclear accidents (IAEA-TECDOC, 2011)(Eisenbud \& Gesell, 1997). To assess the impact of these sources on the environment, measuring the concentration of some primordial nuclides, mainly members of the ${ }^{238} \mathrm{U}$ and ${ }^{232} \mathrm{Th}$ decay chains as well as ${ }^{40} \mathrm{~K}$, is required.

In order to determine the natural activity level and identify NORM in Kabul, a complex geophysical research including radiometric methods was conducted in the city and suburbs of Kabul between 1981 and 1985 by a Soviet geological survey team. During the study gamma dose rates of up to $30 \mu \mathrm{Sv} /$ hour were reported using a SANTALIA SONY Pn-68-1 scintillator in the northern parts of Kabul (Mohmand et al., 1987). Since then residential houses have been built in these areas, while some parts were utilized for rock exploitation, which might have caused health risks for residents and workers (AGS and AAEHC, 2010-2012) 
Meanwhile, abnormal isotope ratios between ${ }^{234} \mathrm{U},{ }^{235} \mathrm{U},{ }^{236} \mathrm{U}$, and ${ }^{238} \mathrm{U}$ were reported in urine of Kabul and Nangarhar residents by the Uranium Medical Research Centre (Durakovic, 2003). In his conclusion Durakovic claims that his finding predicts the use of CBRN (chemical, biological, radiological, nuclear) weapons. Lack of detailed geological information about the area as well as the loss of existing study files make it difficult to assess, whether the sparse available information is reliable or claims on use of nuclear weapons in this area can be trusted. On the other hand, direct discharge of waste into the streams and waste disposal on the land surface are considered the main reason of the water pollution in poorly regulated areas. These wastes may contain detergents, food processing waste, fats, and grease, as well as large amounts of chemical pollutants (Burton et al., 2002). As one of the fast growing cities in south Asia, Kabul has no well-regulated water supply, sewage and sanitation systems in place. New buildings constructed with foreign aid during the last decade have also been poorly regulated and controlled (World Bank, 2015). Different water sources can contain different variety and levels of radioactivity. Increasing pollution with radioactive contaminants poses health problems to the consumers, thus it is important to determine the concentration of different elements in different sources of drinking water (Fawell, 2003). For daughter radionuclides to be present in large concentrations, the parent radionuclide must be present in the rock material composing the aquifer. However, the occurrence of a parent radionuclide in solution does not necessarily indicate the presence of its decay products due to potentially different geochemical behaviour of daughter and the parent element in groundwater (Zapecza et al., 1986).

To verify the existing information and claims, the Afghan Atomic Energy High Commission (AAEHC) in collaboration with Afghan Geology Survey (AGS) launched a sample collection campaign, comprising rock, soil, and water samples from Kabul suburbs. The samples were shipped to the Institute for Radioecology and Radiation Protection (IRS) of the Leibniz Universität Hannover for further analysis. The sample collection had three phases where 50 rock, 1 soil and 51 water samples were collected. Furthermore, radon levels in eight residential houses and four caves were measured using a new radon measurement prototype device developed by Helmholtz Zentrum München (German Research Centre of Environmental Health). The research carried out on these samples is covered within a $\mathrm{PhD}$ work which is discussed in details in this thesis. The first chapter in this 
thesis begins with the motivation and chronology of the sampling sites, which is followed by theoretical aspects of the activity, half-life, dose and equilibrium. The second chapter mentions the experimental setup and the theory behind the experimental setup. It also briefly introduces the devices used in this study. Chapter three is dedicated to the sampling, preparation and measurement methodology, while the results are presented in chapter four along with the evaluation methods. The results of the whole work are then discussed in chapter five followed by references and some appendixes. The first chapter in this thesis begins with the motivation and chronology of the sampling site which is followed by a theoretical aspects of the activity, half-life, dose and equilibrium. The second chapter talks about the experimental setup and the a little of the theory behind the experimental setup, it also briefly introduces the devices used in this study. Chapter three is dedicated to the sampling, preparation and measurement methodology where the results are presented in chapter four along with the evaluation methods. The results of the whole work is then briefed in chapter five followed by references and some appendixes.

\subsection{Environmental Sources of Radiation}

Humans are continuously exposed to radiation throughout the history of life on earth. This radiation comprises charged and uncharged particles as well as gamma and X-rays. All radiation has two common sources namely natural sources and mane-made sources. Excessive radiation levels can pose harmful threat to the human body. Therefore it is necessary to know the sources and analyse the types and doses of radiation to humans (Grupen, 2010). This study focuses on analysis of the natural sources of radiation or so called environmental radiation.

\subsubsection{Natural sources}

Three common types of natural radiation sources are identified namely primordial, radiogenic and cosmogenic sources. Each of these groups of radiation may have different origin but the mechanism of their action and reaction with the environment and living organisms remain the same (Podgoršak, 2014)

\subsubsection{Primordial radionuclides}

Primordial radionuclides are those long lived radionuclides which were formed together with the solar system or maybe even before that (Podosek, 1978). After formation of the 
solar system many of these radionuclides were trapped in rocks. The decay of these trapped nuclides is used for age dating by comparing abundances of radiogenic and nonradiogenic isotopes of one or more elements. These radionuclides can be found among elements of natural decay chains $\left({ }^{238} \mathrm{U},{ }^{235} \mathrm{U},{ }^{232} \mathrm{Th}\right)$ as well as those nuclides which are not part of any decay chain $\left({ }^{40} \mathrm{~K}\right)$. Half-lives of ${ }^{238} \mathrm{U},{ }^{235} \mathrm{U}$, and ${ }^{232} \mathrm{Th}$ are $4.5,0.7$, and 14 billion years, respectively. ${ }^{40} \mathrm{~K}$ has a half-life of 1.3 billion years (Pöschl, 2007).

\subsubsection{Radiogenic radionuclides}

Radiogenic nuclides are formed by the natural decay of unstable nuclides such as ${ }^{238} \mathrm{U}$, ${ }^{235} \mathrm{U}$, and ${ }^{232} \mathrm{Th}$. Their half-lives (The half-life concept is discussed in section 1.3) vary between a fraction of a second and thousands of years. The heavier radiogenic nuclides normally emit charged particles (alpha and beta), often followed by a characteristic gamma emission. Radiogenic nuclides are the main source of the earth's radiogenic heat (Atwood, 2010).

\subsubsection{Cosmogenic radionuclides}

These radionuclides are formed as a result of interaction between high energy cosmic rays with the atoms of the atmosphere (Beer et al., 2012). Cosmogenic isotopes are produced in the atmosphere and at the surface of the earth by direct cosmic ray irradiation of atoms in solid geologic materials. Their half-lives range from seconds to several thousands of years. They are the main nuclides for water dating and have a far shorter halflife than the geological age of the sample (Dunai, 2010).

\subsubsection{Radioactive decay and decay chains}

Radioactive decay or radioactivity is a process of transformation between unstable and stable nuclides. In this process, the unstable or so called radioactive nuclide loses its energy by emitting radiation in either form of alpha or beta particles, gamma quants, or protons. If these transformations do not directly result in a stable product, but in a series of radioactive decays of different radioactive decay products as a sequential series of transformations, it is called radioactive decay chain (Thoennessen, 2016). One of the most important radionuclides that is not part of a decay chain is ${ }^{40} \mathrm{~K}$. It is considered the largest source of natural radioactivity in human beings, animals, and food. Natural potassium is composed of $93.2581 \%$ of ${ }^{39} \mathrm{~K}, 6.7302 \%$ of ${ }^{41} \mathrm{~K}$, which both are stable, and $0.0117 \%$ of 
${ }^{40} \mathrm{~K}$ (IAEA, 2002). This radioisotope, besides ${ }^{238} \mathrm{U}$ and ${ }^{232} \mathrm{Th}$, is the third source of the earth's radiogenic heat (Mussett \& Khan, 2000).

The decay scheme of ${ }^{40} \mathrm{~K}$ is shown in Fig.1.1. With a probability of $89.33 \%,{ }^{40} \mathrm{~K}$ undergoes a beta minus $\left(\beta^{-}\right)$decay and converts to ${ }^{40} \mathrm{Ca}$. With a lower probability of $10.67 \%$ it can also undergo electron capture and convert to the metastable state of ${ }^{40 \mathrm{~m}} \mathrm{Ar}$ which subsequently emits a gamma quant of $1460.81 \mathrm{keV}$ and transforms into stable ${ }^{40} \mathrm{Ar}$ (Attrep \& Kahn, 2007).

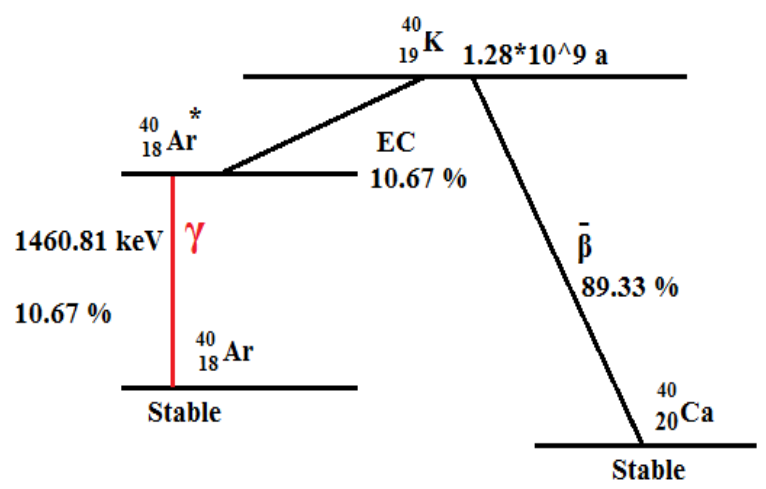

Fig. $1.1{ }^{40} \mathrm{~K}$ decay scheme

The following diagram (Fig.1.2) illustrates the three main radioactive decay chains, usually called thorium, uranium, and actinium decay chain. Due to the relative short half-life $\left(2.144 \times 10^{6} \mathrm{y}\right)$ of its starting isotope ${ }^{237} \mathrm{~Np}$, the neptunium decay series is considered extinct. 


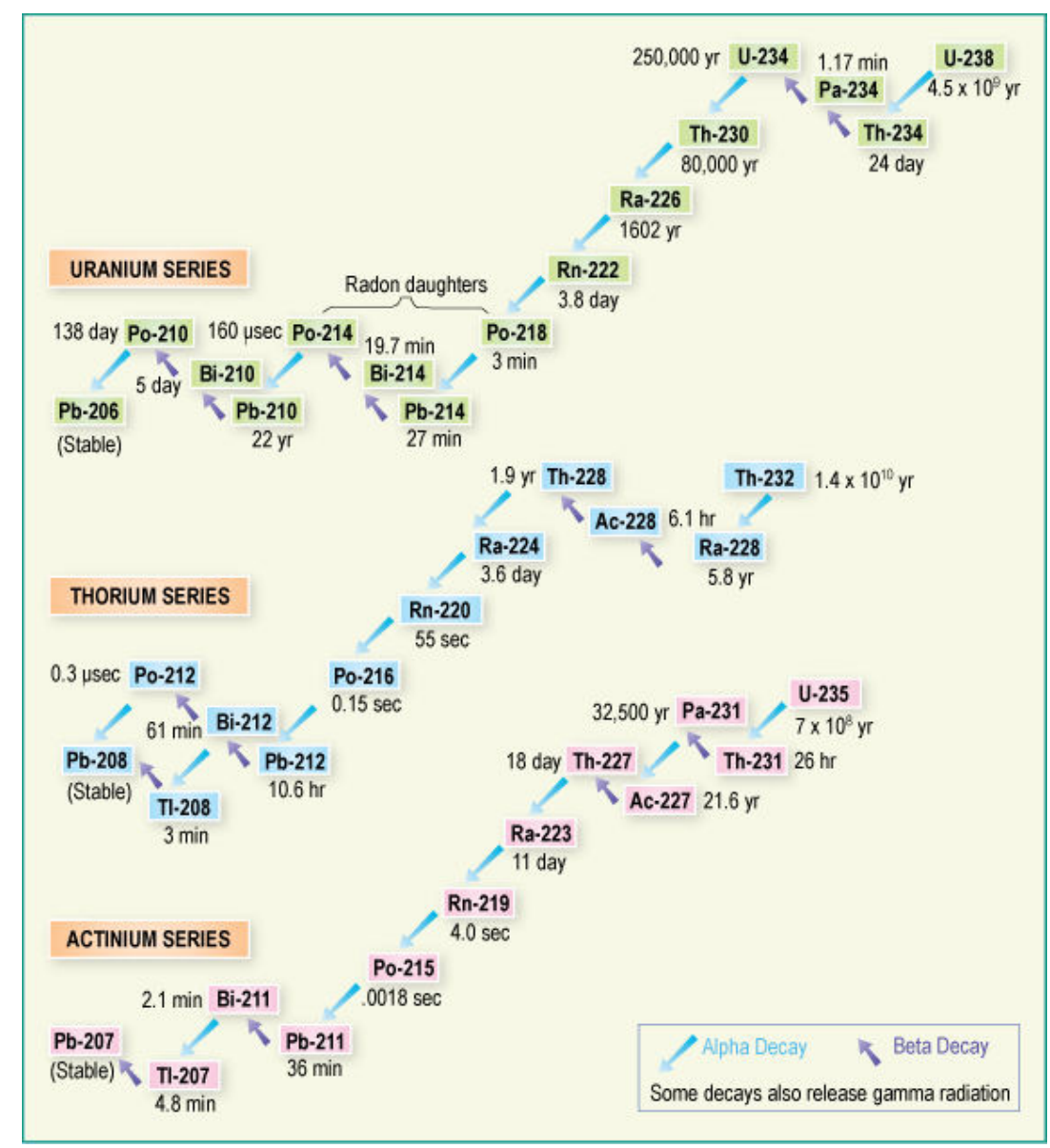

Fig.1.2 Uranium - radium $\left({ }^{238} \mathrm{U}\right)$, thorium $\left({ }^{232} \mathrm{Th}\right)$ and uranium-actinium $\left({ }^{235} \mathrm{U}\right)$ natural radioactive decay chains (WNA, 2016)

All of the series start with a primordial mother nucleus followed by a series of unstable daughter nuclides until they reach the stable state. In case of normal abundance in nature the activity ratio between ${ }^{238} \mathrm{U}$ and ${ }^{235} \mathrm{U}$ is calculated as 21.7 (Minteer et al., 2007).

\subsubsection{Man-made radionuclides}

Radioisotopes which do not exist naturally and are produced by human activities via direct or indirect processes are called artificial, man-made or anthropogenic radionuclides. The major sources of such radionuclides are nuclear weapons tests, operation of nuclear power plants, uranium mining and milling activities, commercial nuclear fuel reprocessing, isotope production facilities and fallout from nuclear accidents. Important examples of these artificial radionuclides posing threat to the environment are plutonium, ${ }^{137} \mathrm{Cs}$ and ${ }^{131} \mathrm{I}$ which are produced in nuclear power plants (Hu et al., 2010). 
${ }^{137} \mathrm{Cs}$, which is produced by ${ }^{235} \mathrm{U}$ fission, has a half-life of 30.17 years. It disintegrates via beta minus emission with a $5.6 \%$ probability to the ground state of ${ }^{137} \mathrm{Ba}$, and with a 94.4\% probability to ${ }^{137 \mathrm{~m}} \mathrm{Ba}$, having a half-life of $2.52 \mathrm{~min} .{ }^{137 \mathrm{~m}} \mathrm{Ba}$ emits a $661.6 \mathrm{keV}$ gamma quant, which is used as an easy detectable indicator of the presence of ${ }^{137} \mathrm{Cs}$ (Gilmore, 2008). Cesium chemically acts like potassium, and is therefore easily accumulated by plants, where the gamma line makes it easy to detect and trace (Gupta \& Walther, 2017). The schematic of ${ }^{137} \mathrm{Cs}$ disintegration is shown in Fig.1.3.

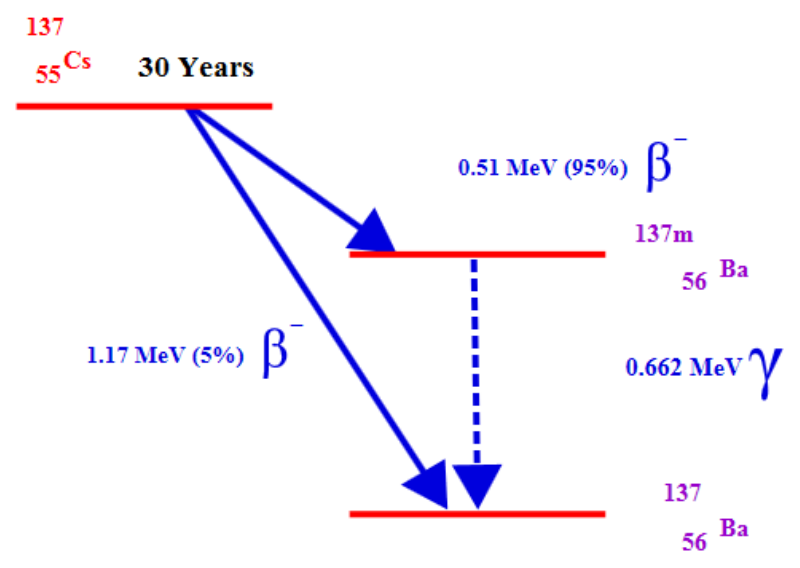

Fig.1.3 ${ }^{137}$ Cs decay scheme.

From 1945 to 1998 more than 2000 nuclear tests contributed to the enhancement of environmental radioactivity (CTBTO, 2017). Besides that, the two major nuclear accidents of Chernobyl and Fukushima caused severe radiological contaminations. The global release of ${ }^{137} \mathrm{Cs}$ and ${ }^{131} \mathrm{I}$ originating from atmospheric nuclear tests are reported to be 948 PBq and $675 \times 10^{3} \mathrm{PBq}$, respectively (UNSCEAR, 2000), the total atmospheric release from Chernobyl and Fukushima accidents are reported to be 85 and $8.8 \mathrm{PBq}$ for ${ }^{137} \mathrm{Cs}$, and 1760 and $120 \mathrm{PBq}$ for ${ }^{131}$ I, respectively (Chernobyl Forum, 2005; UNSCEAR, 2014).

\subsection{Environmental Sources of Radiation}

\subsubsection{Half-life}

The time interval required for a radionuclide to decrease the number of its nuclei to half of the original number is called half-life. It is denominated $T_{1 / 2}$ and is a function of the number of decayed nuclides vs time (Grupen \& Rodgers, 2016). If the initial number of radionuclides is indicated by $\mathrm{N}_{0}$, after the first half-life the number of remaining nuclei would be $\mathrm{N}_{0} / 2$, after the second half-life $\mathrm{N}_{0} / 4$ and so on. 


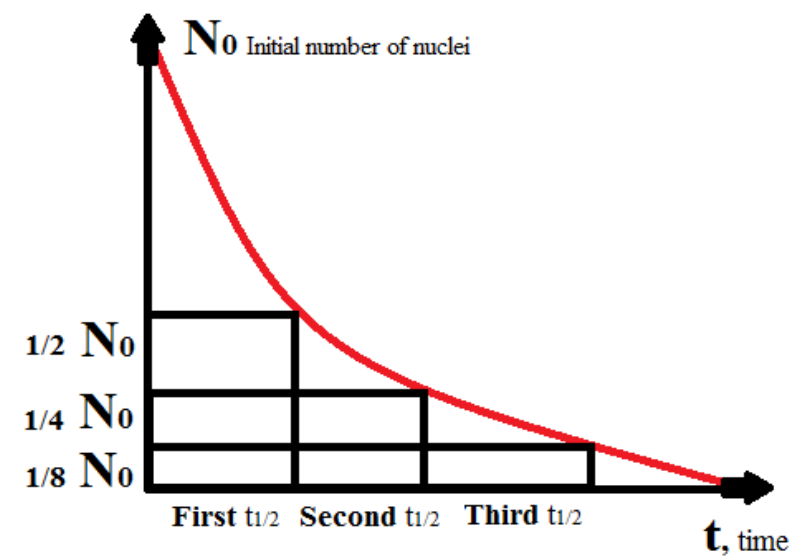

Fig.1.4 Number of surviving nuclides as a function of time during radioactive decay

\subsection{Law of radioactive decay, equilibrium and dose}

\subsubsection{Law of radioactive decay}

If $\mathrm{N}_{\mathrm{t}}$ is the number of radioactive nuclei at a given time $\mathrm{t}, \mathrm{dN}_{\mathrm{t}}$ is the decrease in this number in a time interval (dt). It can be written as $-\mathrm{dN}_{\mathrm{t}}$. The decay rate $(\mathrm{A})$ is defined as the number of disintegrations per unit of time:

$$
\mathrm{A}=-\frac{\mathrm{dN}_{t}}{\mathrm{dt}} \quad 1.1
$$

Where $\mathrm{A}$ is the activity in Becquerel $\mathrm{Bq}, \mathrm{N}_{\mathrm{t}}$ is the number of nuclei not yet decayed and $\lambda$ is the decay constant per unit time $t$.

The number of radioactive decays per unit time is proportional to the number of precursor nuclei: $\frac{\mathrm{dNt}}{\mathrm{dt}} \sim-\mathrm{N}$. In order to make it an equation, the decay rate $\lambda$, which indicates the probability of the decay of nuclei per second $(\lambda)$, is inserted: $-\frac{\mathrm{dNt}}{\mathrm{dt}}=\lambda \mathrm{Nt} \quad 1.2$

Each nuclide has a specific decay rate. If the initial number of nuclei is given by $\mathrm{N}_{0}$, the solution of Eq. 1.2 for $\lambda$ will be (Grupen, 2010):

$$
\mathrm{N}_{\mathrm{t}}=\mathrm{N}_{0} \mathrm{e}^{-\lambda \mathrm{t}} \quad 1.3
$$

Using the logarithm for the terms on both sides and solving the equation for $\mathrm{T}_{1 / 2}$ gives: 


$$
\mathrm{T}_{1 / 2}=\frac{\ln 2}{\lambda}=\frac{0.693}{\lambda}
$$

And the life time or mean time $\mathrm{T}_{\text {mean }}$ is equal to:

$$
\mathrm{T}_{\text {mean }}=\frac{1}{\lambda}=\frac{\mathrm{T}_{1 / 2}}{\ln 2}=\frac{\mathrm{T}_{1 / 2}}{0.693}
$$

As mentioned in section 1.2.1.4, a mother nuclide of any natural decay series will decay until it reaches the final stable state Fig.1.6.

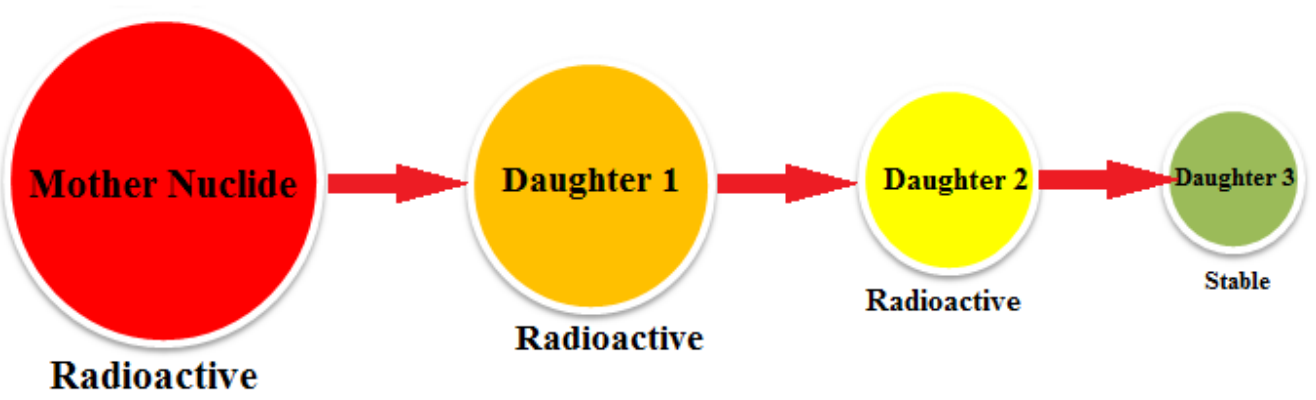

Fig.1.6 Decay chain of a radioactive nucleus

Considering this assumption in the law of radioactive decay, we can write:

$$
\begin{gathered}
\frac{d N_{M}}{d t}=-\lambda N_{M} \\
\frac{d N_{1}}{d t}=+\lambda N_{M}-\lambda N_{1} \\
\frac{d N_{2}}{d t}=\mp \lambda N_{1}-\lambda N_{2} \\
\frac{d N_{n}}{d t}=+\lambda_{n-1} N_{n-1}-\lambda_{n} N_{n}
\end{gathered}
$$

For the initial time $t=0$ the number of daughter nuclei is: $N_{n}(0)=0$, and for the case $\mathrm{n}=2$ time $\mathrm{t}$ and number of nuclei $\mathrm{N}_{\mathrm{n}}(\mathrm{t})$ one gets:

$$
N_{2}(\mathrm{t})=\frac{\lambda_{1}}{\lambda_{2}-\lambda_{2}} * N_{1}(0) *\left(\mathrm{e}^{-\lambda_{1} \mathrm{t}}-\mathrm{e}^{-\lambda_{2} \mathrm{t}}\right)+N_{2}(0) * \mathrm{e}^{-\lambda_{2} \mathrm{t}}
$$


A more general solution for an arbitrary natural number $\mathrm{n}$ was provided by Bateman and can be found e.g. in (Magill \& Galy, 2005).

The activity of $\mathrm{n}^{\text {th }}$ nuclide can be written as:

$$
\mathrm{A}_{\mathrm{n}}(\mathrm{t})=\lambda_{\mathrm{n}} * \mathrm{~N}_{\mathrm{n}}(\mathrm{t})
$$

where $A_{n}(t)$ is the activity of the $n^{\text {th }}$ nuclide after the time $(t)$ and $\lambda$ is the decay constant for the $\mathrm{n}^{\text {th }}$ nuclide.

\subsubsection{Radioactive equilibria}

Based on the discussion in the previous section we now consider the case we consider an ensemble of parent nuclei of a decay chain allowed to disintegrate for a long period of time until the activity ratios between the parent and the daughters reach constant values: parent and daughter nuclides are in equilibrium. For the case $n=1$, the activity of daughter nuclides can be written as:

$$
\begin{array}{r}
\frac{d_{M}}{d t}=-\lambda_{M} N_{M} \text { and } \frac{d N_{D}}{d t}=-\lambda_{D} N_{D}+\left(\lambda_{M} N_{M}\right) \\
N_{D}(t)=N_{M}(0) \frac{\lambda_{M}}{\lambda_{D}-\lambda_{M}}\left(e^{-\lambda_{M} t}-e^{-\lambda_{D} t}\right)+N_{D}(0) e^{-\lambda_{D} t}
\end{array}
$$

As the activity of mother nuclides is $A_{M}=\lambda_{M} N_{M}$ and the activity of daughter nuclides is $A_{D}=\lambda_{D} N_{D}$, therefore we obtain:

$$
A_{D}(t)=A_{M}(0) \frac{\lambda_{D}}{\lambda_{D}-\lambda_{M}}\left(e^{-\lambda_{M} t}-e^{-\lambda_{D} t}\right)+A_{D}(0) e^{-\lambda_{D} t}
$$

The equation for determining the activity of the daughter nuclide is called the Bateman equation (Bateman, 1843). In terms of activity level mother and daughter nuclides can have three types of relation between each other. They are either in a secular equilibrium, in a transient equilibrium or they have no equilibrium at all.

\subsubsection{Secular Equilibrium}

If the half-life of a mother nuclide is more than $10^{4}$ times longer than that of the daughter nuclide, the type of relationship is called secular equilibrium (Ahmed, 2015). As mentioned in section 1.4.1, the higher the decay constant the faster is the disintegration. Thus, 
in a secular equilibrium the decay constant for the long-lived primordial parent nuclei is negligible. Fig.1.7 shows a secular equilibrium plot between parent and daughter nuclides.

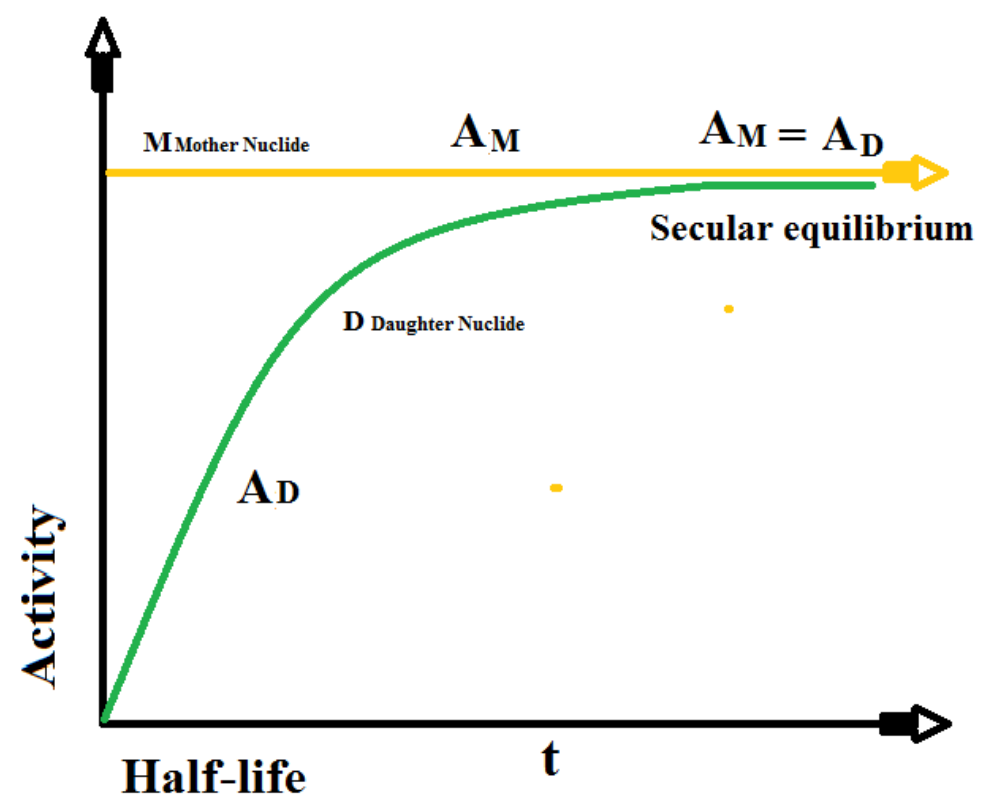

Fig.1.7 Secular equilibrium between parent and daughter nuclides

As shown in Fig.1.7 $T_{1 / 2 M}>>T_{1 / 2 D}$ and $\lambda_{M}<<\lambda_{D}$, which can be written as $\lambda_{D}-\lambda_{M} \approx \lambda_{D}$. If the initial number of nuclei $\mathrm{N}_{0}=0$, Eq.1.9 results in:

$$
\mathrm{N}_{\mathrm{D}}(\mathrm{t})=\mathrm{N}_{\mathrm{M}}(\mathrm{t}) \frac{\lambda_{\mathrm{M}}}{\lambda_{\mathrm{D}}}\left(1-\mathrm{e}^{-\lambda_{\mathrm{D}} \mathrm{t}}\right) \quad 1.11
$$

and if we calculate the second term of the right hand side of the equation 1.11 for a long period of time, i.e. $\lim _{t \rightarrow \infty} \mathrm{e}^{-\lambda_{\mathrm{D}} \mathrm{t}}=0$, equation 1.11 is transformed to:

$$
N_{D}(t)=N_{M}(t) \frac{\lambda_{M}}{\lambda_{D}} \quad \text { and } \quad A_{M}=\lambda_{M} N_{M}=\lambda_{D} N_{D}=A_{D}
$$

If the Eq.1.13 conditions are met by parent and daughter nuclide, the activity ratio between mother and daughter nuclides is one $\left(A_{D} / A_{M}=1\right)$, which means they are in secular equilibrium and have the same activity. The optimum time frame for the daughter nuclide to reach the activity rate of its parent nuclide is a factor of 10 of the daughter half-life (Lieser, 2008). 


\subsubsection{Transient Equilibrium}

If the half-life of the parent nuclide is larger than that of the daughter, but not more than 10 times, the resulting equilibrium is called transient equilibrium. When transient equilibrium conditions are met, the activity of the daughter nuclide may even exceed that of the parent nuclide. When it reaches the maximum, the activity of the daughter decreases with the half-life of the parent nucleus. Fig.1.8 shows a transient equilibrium plot between parent and daughter nuclides.

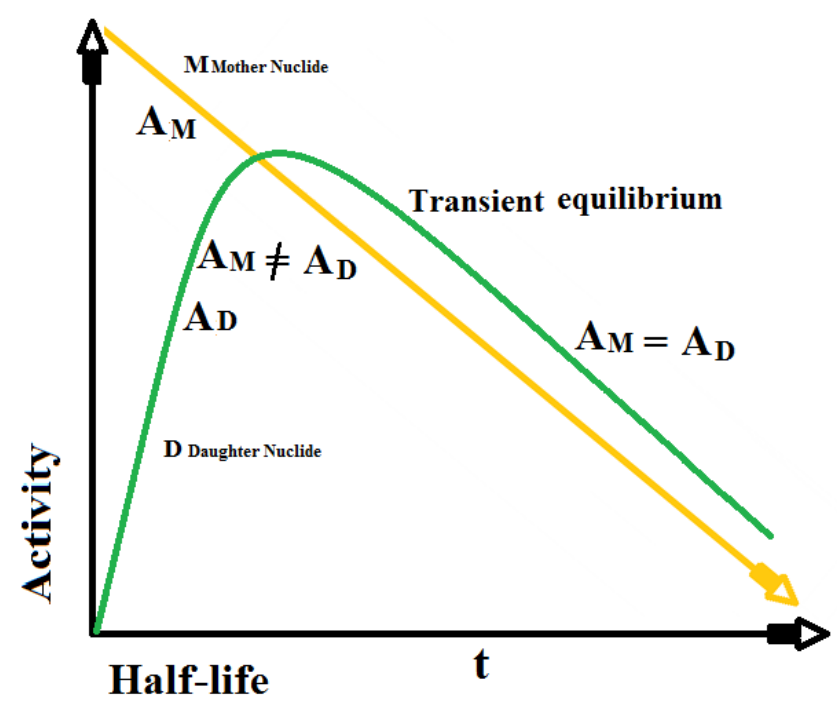

Fig.1.8 Transient equilibrium between parent and daughter nuclides

As shown in Fig.1.8, $\mathrm{T}_{1 / 2 \mathrm{M}}>\mathrm{T}_{1 / 2 \mathrm{D}}$ and $\lambda_{\mathrm{M}}<\lambda_{\mathrm{D}}$, so the decay constant of the parent nuclide is not negligible, in contrast to the secular equilibrium. Taking into account that $\mathrm{N}_{0}=0$ and $\lim _{\mathrm{t} \rightarrow \infty} \mathrm{e}^{-\lambda_{\mathrm{D}} \mathrm{t}}=0$, solving Eq.1.9 for transient equilibrium results in a ratio between parent and daughter nuclides given in Eq 1.13:

$$
\frac{\mathrm{N}_{D}(\mathrm{t})}{\mathrm{N}_{\mathrm{M}}(\mathrm{t})}=\frac{\lambda_{\mathrm{M}}}{\lambda_{\mathrm{D}}-\lambda_{\mathrm{M}}} \quad 1.13
$$

As the transient equilibrium is reached, the activity ratio between parent and daughter nuclide is constant and lager than one:

$$
\frac{\mathrm{A}_{\mathrm{D}}}{\mathrm{A}_{\mathrm{M}}}=\text { Const. }>1
$$


In this case, the total activity $\left(A_{M}+A_{D}\right)$ decreases according to the half-life of the parent nuclide (L'Annunziata, 2012).

\subsubsection{No or zero equilibrium}

When the daughter nuclide has a larger half-life than that of the parent, there is no chance that they will be in any kind of radioactive equilibrium. In this case, the daughter activity is growing until the parent nuclide has fully decayed. The none-equilibrium relation between parent and daughter nuclides is shown in Fig.1.9.

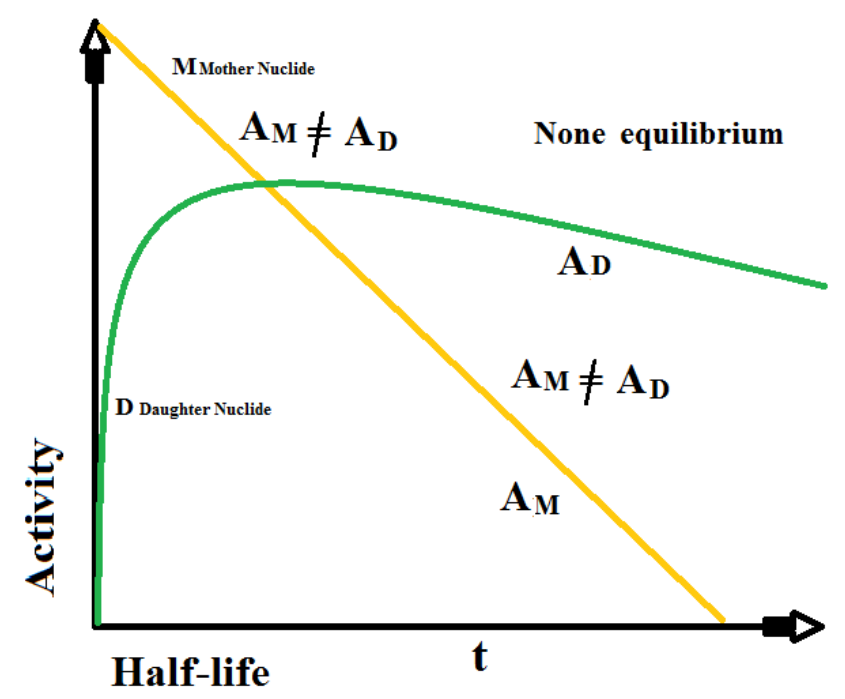

Fig.1.9 None-equilibrium state between parent and daughter nuclides

As shown in Fig.1.9 $\mathrm{T}_{1 / 2 \mathrm{M}}<\mathrm{T}_{1 / 2 \mathrm{D}}$ and $\lambda_{\mathrm{M}}>\lambda_{\mathrm{D}}$, which means the decay constant is not negligible. Taking into account that $\mathrm{t} \rightarrow \infty$ is not constant and $\lim _{\mathrm{t} \rightarrow \infty} \mathrm{e}^{-\lambda_{\mathrm{D}} \mathrm{t}}$ and where $\mathrm{e}^{-\left(\lambda_{\mathrm{D}}-\lambda_{\mathrm{M}}\right) \mathrm{t}}$ diverges, the ratio between parent and daughter nuclides can be expressed as:

$$
\frac{N_{D}(t)}{N_{M}(t)}=\frac{\lambda_{M}}{\lambda_{D}-\lambda_{M}}\left(1-e^{-\left(\lambda_{D}-\lambda_{M}\right) t}\right)
$$

The most favourable case is the secular equilibrium, when the activity ratio of parent and daughter nuclides reaches $99.9 \%$ after the $10^{\text {th }}$ half-life (Washington $\&$ Leaver, 2016).

\subsubsection{Radiation dose}

The radiation dose represents a measure for the energy of ionizing radiation absorbed by matter. Dose types and units differ with respect to radiation type and energy as well as 
the accumulation target (Vogt et al., 2011). To make controlled use of radiation, a number of rules, regulations, code of good conduct and guidance are proposed on the base of radiation science and knowledge (IAEA, 2014b). Dose can be categorized mainly into absorbed dose, equivalent dose, and effective dose.

\subsubsection{Absorbed dose}

The amount of energy from ionizing radiation deposited per unit mass is called the absorbed dose D. The unit of the absorbed dose is Gray (Gy). One Gray is equal to 1 Joule of radiation energy absorbed by $1 \mathrm{~kg}$ of (tissue) mass (Knoll, 2010).

\subsubsection{Equivalent dose}

The level of biological effects caused by ionizing radiation deposited in an organ tissue $\mathrm{T}$ is the equivalent dose $\mathrm{H}_{\mathrm{T}}$. It is equal to the absorbed dose $\mathrm{D}_{\mathrm{T}, \mathrm{R}}$ of the radiation $\mathrm{R}$ in organ $T$ multiplied by the weighting factor $\mathrm{w}_{\mathrm{R}} \cdot \mathrm{w}_{\mathrm{R}}$ is a function of the radiation type $\mathrm{R}$. The unit of equivalent dose is given in Sievert (Sv):

$$
\mathrm{H}_{\mathrm{T}}=\sum_{\mathrm{R}} \mathrm{w}_{\mathrm{R}} \mathrm{D}_{\mathrm{T}, \mathrm{R}} \quad 1.16
$$

For assessment of the equivalent dose, the type of radiation is important, which is taken into account by using the weighting factor. Due to its high relative biological effectiveness to cause biological damage, alpha radiation is about 20 times more dangerous than an equivalent activity of beta or gamma emitting radioisotopes (ICRP, 2007).

\subsubsection{Effective dose}

The effective dose $\mathrm{E}$ is a measure of a total body dose for all specified tissues and organs. Introducing one additional weighting factor $\mathrm{w}_{\mathrm{T}}$ of the tissue $\mathrm{T}$, the effective dose is calculated as:

$$
\mathrm{E}=\sum_{\mathrm{T}} \mathrm{w}_{\mathrm{T}} \sum_{\mathrm{R}} \mathrm{w}_{\mathrm{R}} \mathrm{D}_{\mathrm{T}, \mathrm{R}} \text { or } \quad \mathrm{E}=\sum_{\mathrm{T}} \mathrm{w}_{\mathrm{T}} \mathrm{H}_{\mathrm{T}}
$$

where $H_{T}$ or $\mathrm{w}_{R} \mathrm{D}_{T, R}$ is the equivalent dose in a tissue or organ, $\mathrm{T}$, and $\mathrm{W}_{\mathrm{T}}$ is the tissue weighting factor. The unit of effective dose is given in Sievert (Sv) (ICRP, 2007).

In short: 
Absorbed dose assesses the potential of biochemical changes in specific tissues.

Equivalent dose assesses the expected biological damage from an absorbed dose.

Effective dose assesses the potential of long-term effects in the future.

As mentioned in the previous section, human beings are continuously exposed to environmental radiation from different sources. - The effective dose limit for members of the public is $1 \mathrm{mSv} / \mathrm{a}$, while for workers the dose limit is $20 \mathrm{mSv} / \mathrm{a}$ (ICRP, 2007). More than half of the natural radiation originates from inhalation of radon and its progenies (BFS, 2015). The worldwide average annual effective dose including radon is reported to be 2.4 mSv (UNSCEAR, 2008). In large populations, about $65 \%$ of the members receive doses between 1 and $3 \mathrm{mSv}$. About $25 \%$ of the population receive less than $1 \mathrm{mSv}$, and about $10 \%$ receive more than $3 \mathrm{mSv}$ (UNSCEAR, 2000). 


\section{Chapter}

\section{Experimental setup}

In this chapter, the devices and methods that were used to carry out the measurements will be discussed based on their structures, functionalities as well as their measurement abilities.

\subsection{Gamma ray interaction with matter}

A detector will be able to record a radiation incident only when the radiation interacts with the medium of the detector. In order for a gamma ray to be detected by the detector, the incident gamma photon must transfer all or at least some of its energy to the detector. The mechanism of this loss has a direct relation to the properties of the incident gamma photon, the energy loss mechanism is an important indicator of the detector type (Grupen \& Shwartz, 2008).

\subsubsection{Photo-electric effect PEE}

A photoelectric effect occurs when a photon hits an atom and all the energy of this incident photon is transferred to an electron in a shell close to the nucleus, mainly in the $\mathrm{K}$ and $\mathrm{L}$ shells. The electron receives kinetic energy from the incident photon and is ejected from the shell (Fig. 2.1).

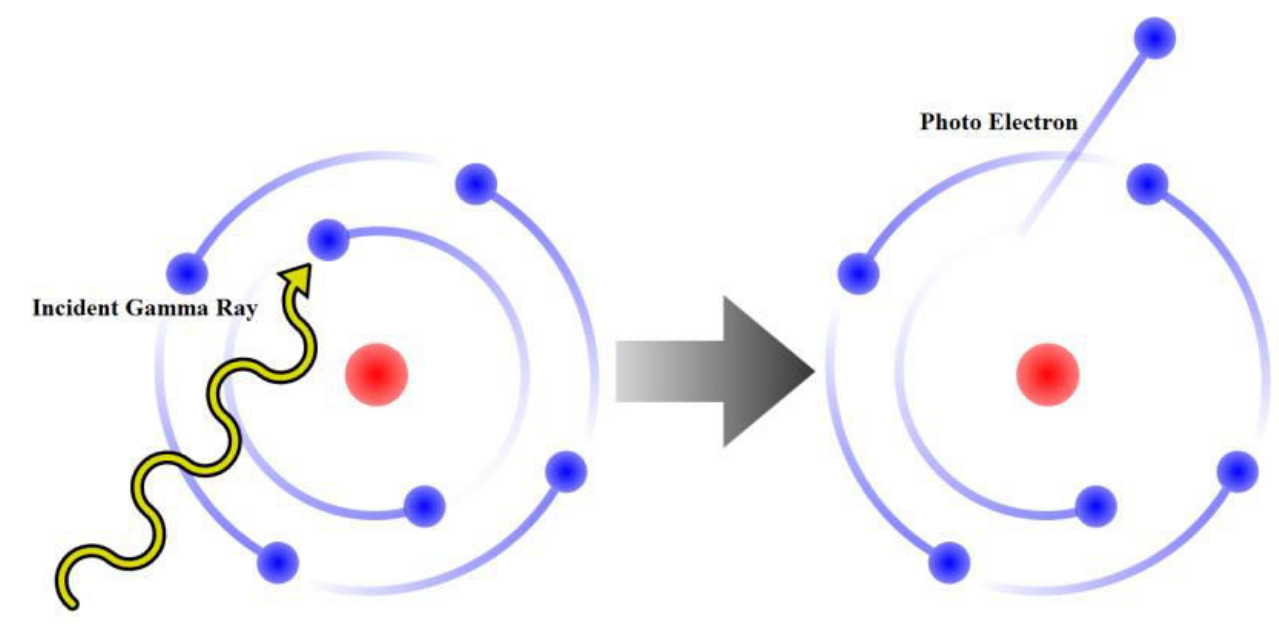

Fig.2.1: Photo electron produced by an incident gamma photon via photoelectric effect. 
An incident photon able to cause an electron to be ejected from its shell, must have energy equal or greater than the binding energy of the ejected electron. The ejected electron may cause a secondary ionization in the medium as well. The incident photon will deposit all of its energy and will disappear. If the incident photon energy is $\mathrm{E}_{\gamma}=\mathrm{h} v$ and $v=\frac{\mathrm{c}}{\lambda}$, the kinetic energy transferred to the ejected electron can be written as:

$$
\mathrm{E}_{\mathrm{ke}}=\mathrm{h} v-\mathrm{E}_{\mathrm{B}},
$$

where $h$ is the Planck constant, $\lambda$ is the wavelength of the incident photon, $E_{k e}$ is the kinetic energy, and $E_{B}$ is the binding energy of the electron in a particular shell (Gilmore, 2008).

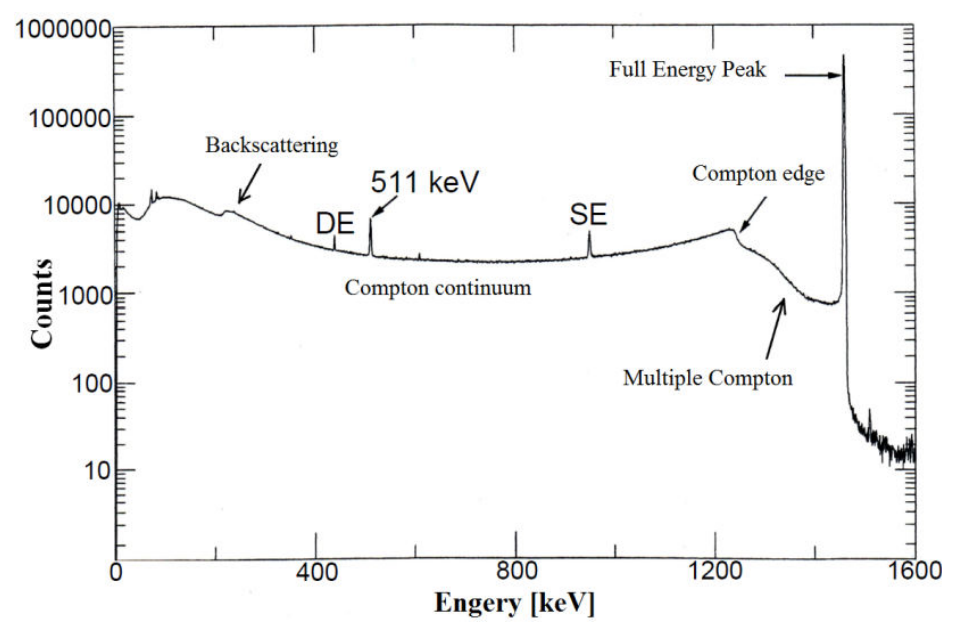

Fig.2.2: Spectrum of K-40 with the Compton continuum and the characteristic full energy peak at $1461 \mathrm{keV}$ (Knoll, 2010).

The photon may also eject an electron from the shells not close enough to nucleus. With increasing distance of the electron from the nucleus the probability of the photoelectric effect decreases. Photoelectric effect has a higher probability of occurrence in materials with higher atomic numbers (Attix, 1986).

\subsubsection{Compton scattering CS}

Compton scattering occurs when an incident photon undergoes elastic scattering and transfers a portion of its energy to an electron of the outer shell. As a result of this scattering, the wavelength of the photon increases while the energy decreases. This effect is 
the most dominant one fore gamma rays interaction with matter, but strongly depending on material $(Z)$ and photon energy. The Compton scattering is illustrated in Fig.2.3.

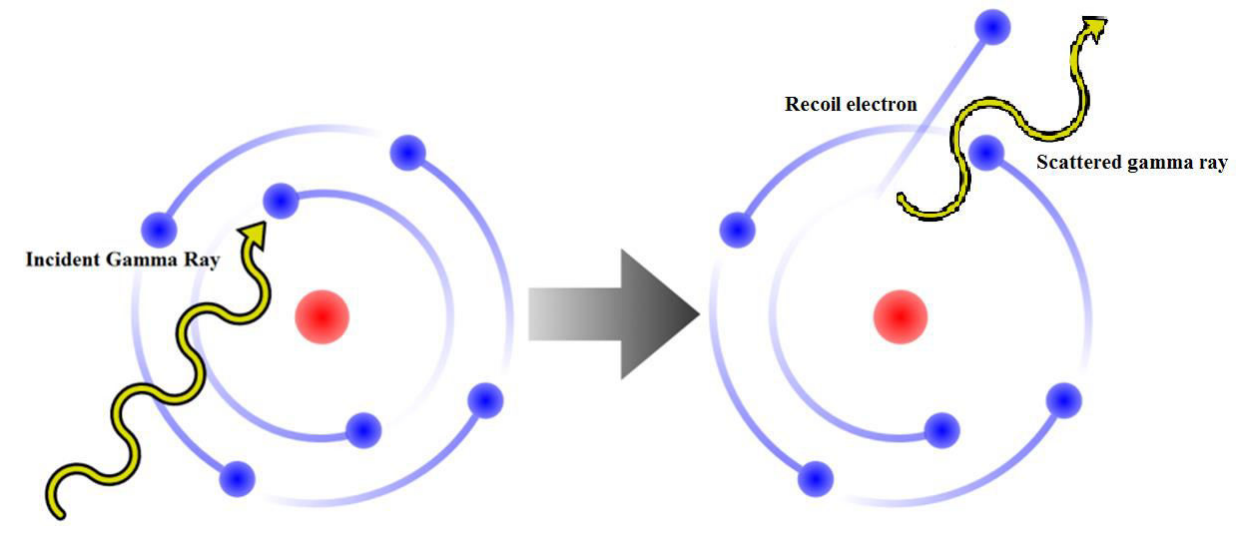

Fig.2.3: Scattered gamma ray as a result of Compton scattering.

To calculate the kinetic energy of the recoil electron, the following equation is used:

$$
\begin{array}{r}
\mathrm{E}_{\mathrm{ke}}=\mathrm{E}_{\gamma}-\mathrm{E}_{\hat{\gamma}} \quad 2.2 \\
\mathrm{E}_{\mathrm{ke}}=\mathrm{E}_{\gamma}-\mathrm{E}_{\gamma} \frac{1}{1+\frac{\mathrm{E}_{\gamma}}{\mathrm{m}_{0} \mathrm{c}^{2}(1-\cos \theta)}}
\end{array}
$$

where $E_{\gamma}$ the energy of the incident photon is, $E_{\hat{\gamma}}$ is the energy of the scattered photon. $E_{k e}$ is the kinetic energy of the Compton electron, $\mathrm{m}_{0}$ is the rest mass of the free electron, and $\theta$ the scattering angle of the incident photon (Gilmore, 2008).

As shown in Fig.2.2, the energy is transferred to the electron reaches its maximum when the scattering angle $\theta$ is 180 degrees. At this angle, the scattered gamma photon has the lowest possible energy.

\subsubsection{Pair production PP}

When a high energy photon interacts with the coulomb field of an atomic nucleus, it converts to an electron -positron pair. In terms of energy, the rest mass of an electron is equal to $511 \mathrm{keV}$; therefore, at least $1022 \mathrm{keV}$ energy is needed to make the pair production possible. If the energy is higher than $1022 \mathrm{keV}$ it is then transferred to the kinetic energy of the newly generated produced pair (L'Annunziata, 2012) . 


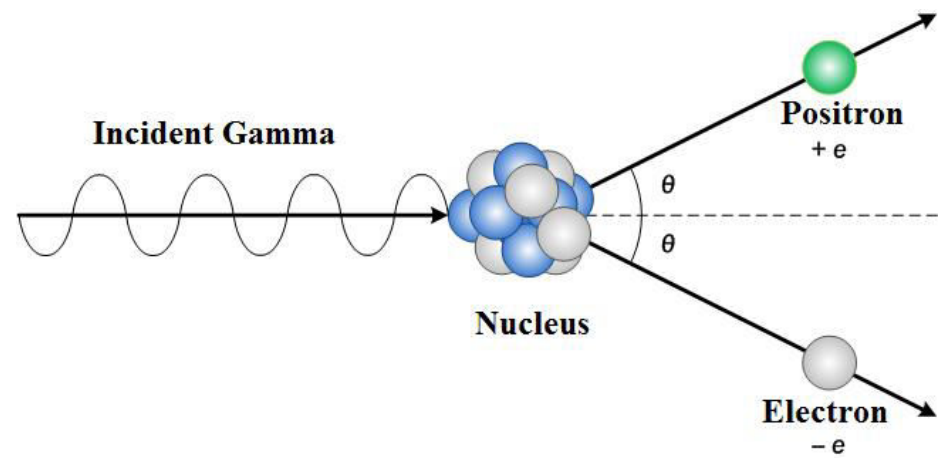

Fig.2.4: Incident gamma converted into pair of electron-positron.

During the detection of these pairs by a germanium detector the reverse process of pair production namely annihilation of electron-positron pairs occurs, which will result in two photons each having the energy of $511 \mathrm{keV}$. If just one of the annihilation gammas escapes and the other one is completely absorbed in the detector, this will result in a single escape peak at the energy of the photopeak (full energy peak) minus $511 \mathrm{keV}$. If both of them escape, the detector records a double escape gamma peak at $1022 \mathrm{keV}$ below the photopeak (See Fig.2.2).

The probability of the occurrence or cross section for the three mechanism mentioned above is shown in Fig.2.5.

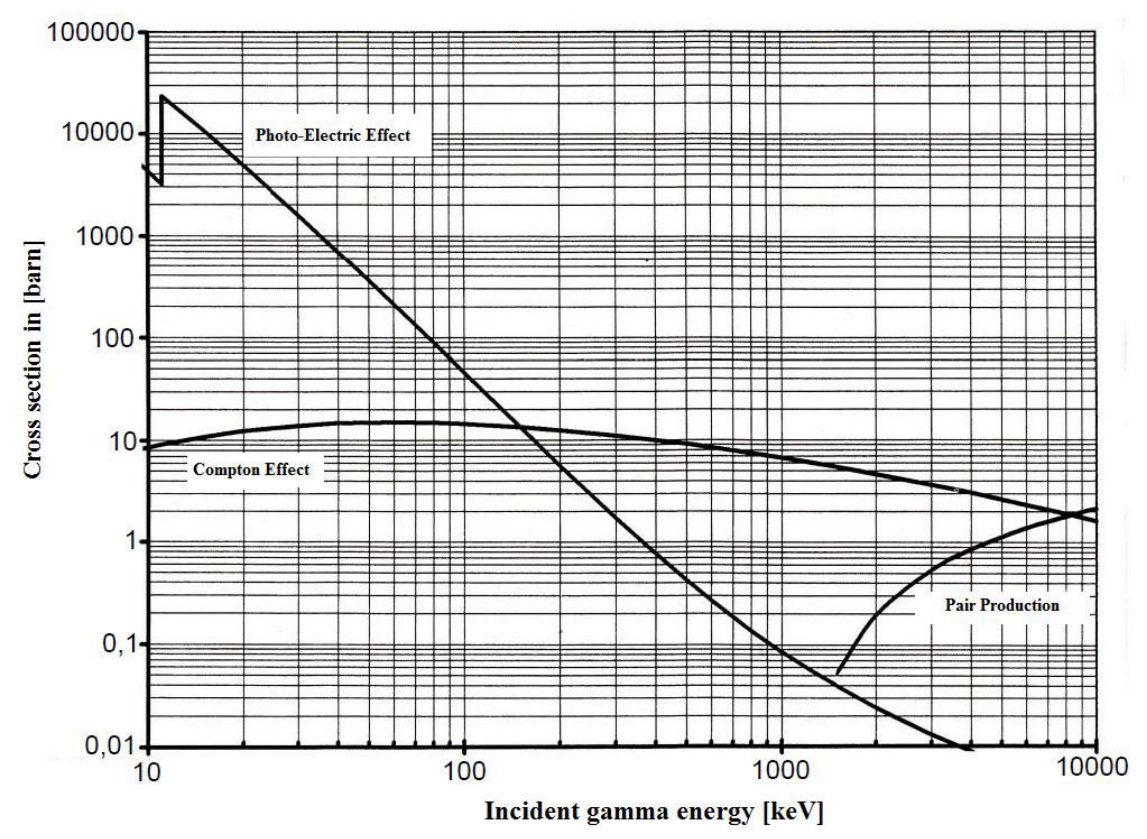

Fig.2.5: Incident gamma energy vs cross section of each individual effect (L'Annunziata, 2012). 


\subsection{Gamma ray spectroscopy}

Gamma ray spectrometry is an analytical method that identifies the gamma emitting radioisotopes on quantitative and qualitative basis. This method is one of the robust methods of measurements which needs very little sample preparation and identifies several radionuclides in a single sample (Gilmore, 2008).

In the system used for our measurements, the emitted gamma energies from the samples are detected in a Germanium crystal that is then converted to a spectrum consisting of several lines. The heights of these lines represent the number of gamma quants absorbed by the system or - after calibration - the amount of activity. The positions of these lines on the $\mathrm{x}$-axis indicate the energies of the emitted gamma photons. Unlike Geiger-Mueller counters, which only measure the rate of absorbed gamma quants, gamma ray spectroscopy systems give information on the count rate as well as the energy of the gamma quants (Kamal, 2014). Such a system has a wide range of applications from research on environmental samples and medical radioisotopes to environmental monitoring of nuclear facilities.

\subsection{Gamma ray detectors}

In general, there are three types of detectors used for measuring gamma rays: gas filled detectors, including ionization chambers and proportional counters, scintillation detectors like sodium iodide (NaI) detectors, and semiconductor detectors as silicon surface barrier (SSB) detectors, germanium-lithium (GeLi) and high purity germanium (HPGe) detectors. The detectors used for the gamma spectroscopic measurements in this study were HPGe detectors. The resolution of HPGe detectors are up to 20-30x better as compared to that of $\mathrm{NaI}$ detectors (Ortec, 2017).

Fig.2.6 shows two spectra of the same sources produced by a sodium iodide - thallium (NaI(Tl)) detector and a high purity germanium detector (HPGe), respectively. Comparison of the two spectra reveals that the peaks recorded by the sodium iodide detector are overlapping, while the peaks produced by the HPGe detector representing the same energy can easily be discriminated. 


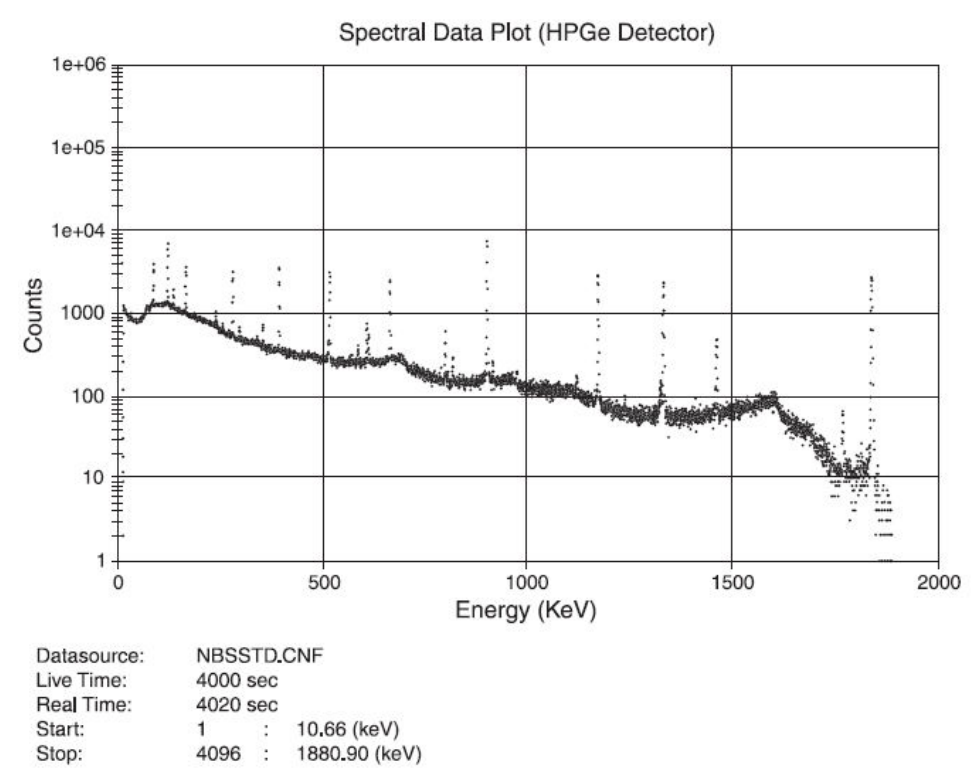

Fig.2.6a

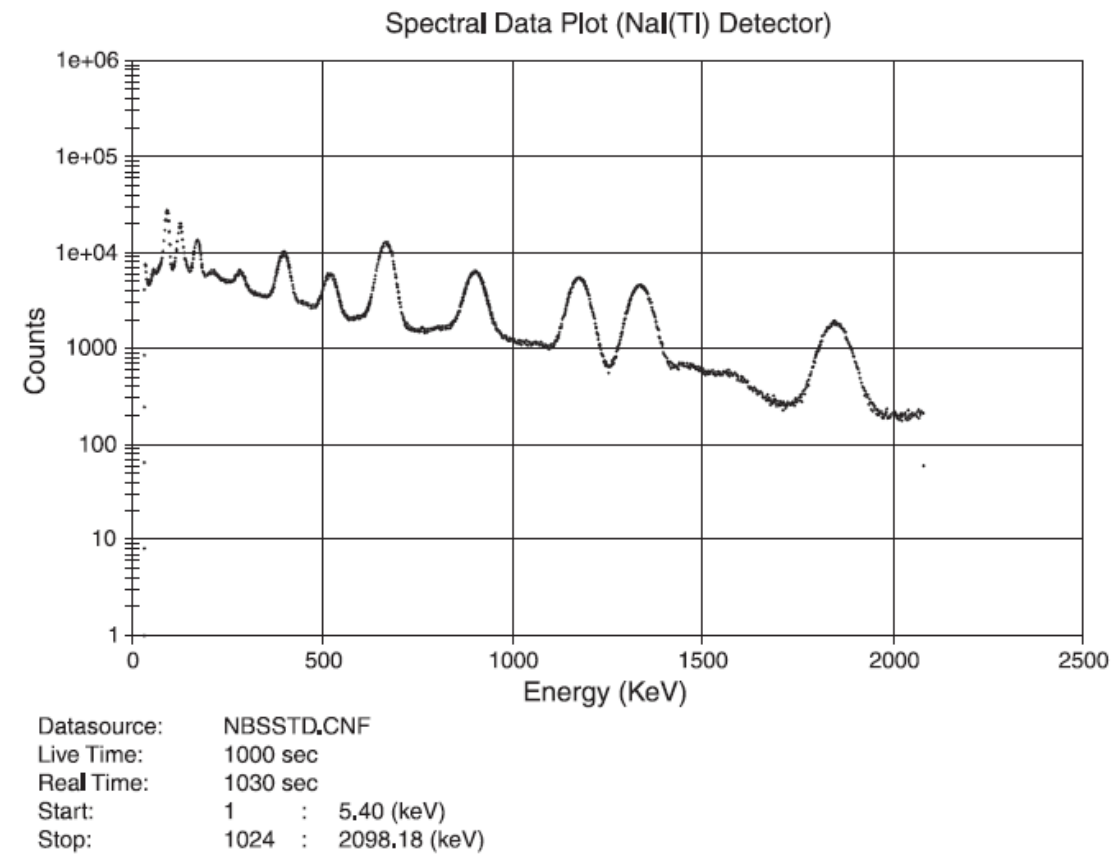

Fig.2.6a

Fig.2.6a and 2.6b: Comparison of spectra originating from the same source recorded by two detectors with different resolutions (Nafaa Reguigui, 2006).

As only HPGe detectors were used as main detection technique for this study, only the theoretical background of semiconductor detectors is discussed here in detail. 


\subsection{Semiconductor detectors}

A detector which uses semiconductor elements such as silicon, and germanium for recording the incident gamma rays are called solid state or semiconductor detectors. Different types of semiconductor detectors have the same detection mechanism: The incident gamma energy ionizes the detector medium and produces free charge carriers. The number of these free charge carriers produced by gamma radiation in a semiconductor detector is proportional to the energy of the incident gamma (Lutz, 2001).

As the energy band gap between valance and conduction band in a semiconductor used in radiation detectors is smaller than $\sim 1 \mathrm{eV}$ in comparison to insulators, the free charge carriers can be generated by very low energies, this can be as low as room temperature equivalent thermal energies. The signal coming from such low energy might be recorded as electronic noise by the detectors. To suppress this noise, liquid nitrogen (LN2) and other cooling systems are used to continuously cool the detector while in operation (Upp et al., 2005).

One of the most frequently used and optimal semiconductor detectors in gamma spectroscopy is the high purity germanium HPGe detector. The crystals were first developed in the middle of 1970s (Theodórsson, 1996). The detection mechanism is as follows:

The small band gap in semiconductor materials facilitate the thermally excited electrons to travel from valence to conduction band, which results in generation of a vacancy, hole or positive charge in the valence band. When biased, the released charge carriers, i.e. electrons and holes, generate an electric current. This current can be enhanced by increasing the concentration of the free charge carriers. The traditional way of this enhancement is doping of the semiconductors with impurities (Shklovskiĭ \& Éfros, 1984). Recently, highly purified semiconductor crystals came into use, enhancing the precision of gamma measurement by reducing conductivity, and thus the noise. If a highly purified germanium detector is cooled down to liquid nitrogen temperature, the conduction band becomes empty or the free zone between $\mathrm{p}$ and $\mathrm{n}$ poles will increase, therefore too low thermal energy won't be able to excite the electron into the conduction band anymore. Only the energy provided by the incident gamma photon enables electrons to go to the conduction bond in the detector. Application of an inverse voltage to the two ends of this p-n junction will cause diffusion of the moving electron and the remaining hole out of the 
detector, and with the help of suitable electronics, the current will be recorded as a gamma energy indicator pulse. The electron-hole pair generation mechanism is illustrated in Fig.2.7.

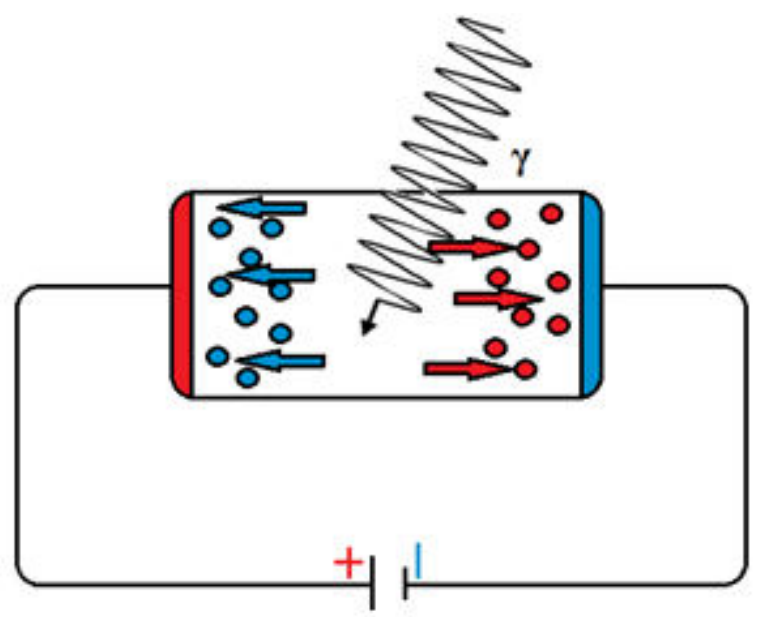

Fig.2.7: Electron-hole pairs produced by incident gamma photons in a semiconductor crystal connected to high voltage.

As shown in Fig.2.7 the germanium crystal used in HPGe detectors consists of a p-n junction which acts like a diode with the reversed biased voltage increasing the active volume of the detector. An n-type crystal has an enhanced amount of free electrons, a thinner depletion layer, higher conductivity, and thus higher efficiency for lower energies, whereas the p-type crystal has an enhanced amount of holes, which decreases conductivity, produces low background noise, and thus is particularly suitable for measuring high gamma energies (L'Annunziata, 2012). The detector used in this study has a coaxial ptype crystal of purified germanium. The schematic internal structure of a liquid nitrogen cooled detector is shown in the following figure: 


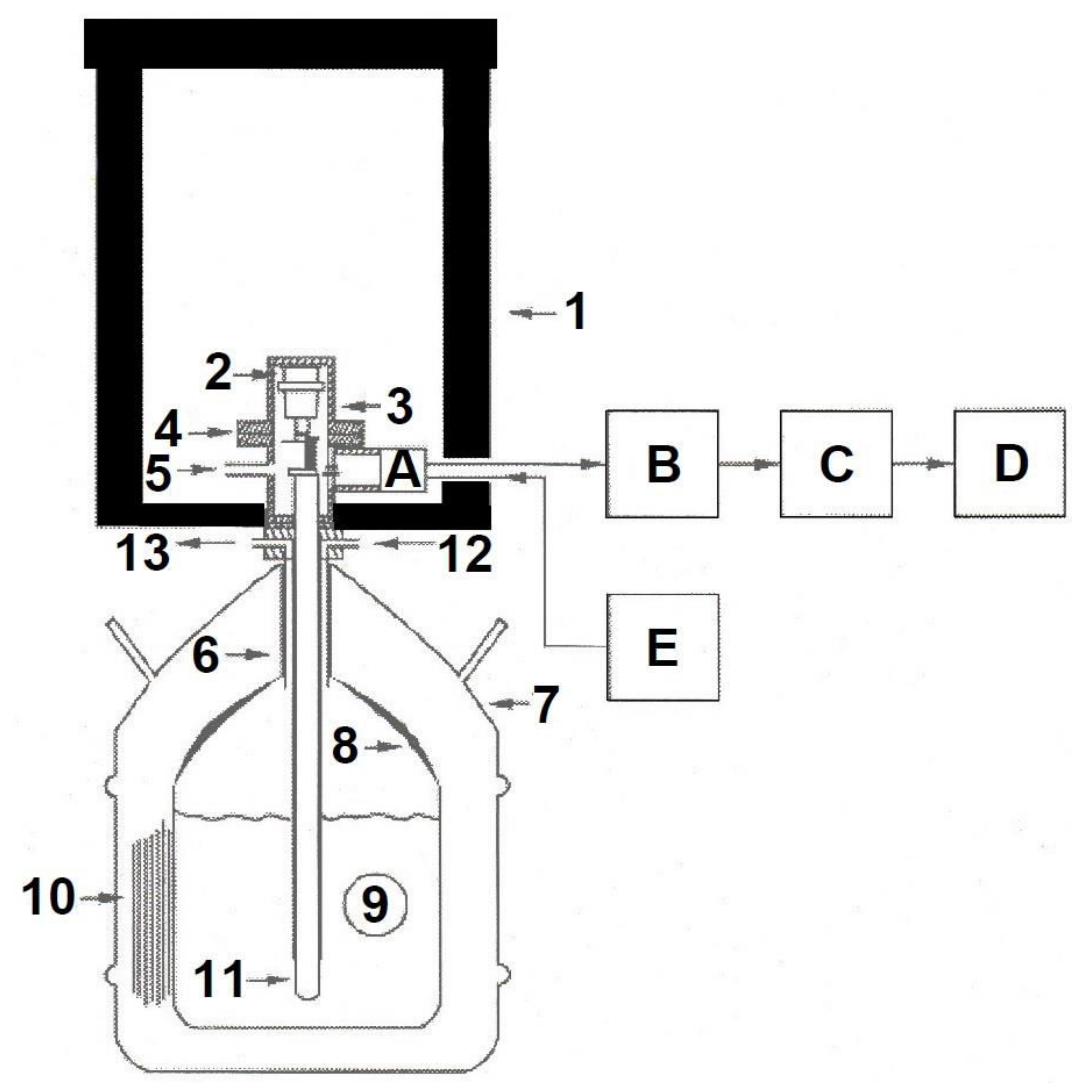

Fig.2.8: Schematic of a semiconductor detector equipped with a germanium crystal (BMUB, 2006).

1. Lead Shielding

2. Germanium crystal detector

3. Endcap

4. Flange

5. Evacuation valve

6. Dewar neck tube

7. Dewar

8. Molecular sieve (Dewar)

9. Liquid nitrogen

10. Insulation

11. Cold finger (copper)

12. Liquid nitrogen filling tube

13. Liquid nitrogen vent tube

A. Preamplifier 

B. Main amplifier
C. Multi-Channel Analyzer - MCA
D. Spectra evaluation and documentation
E. High voltage

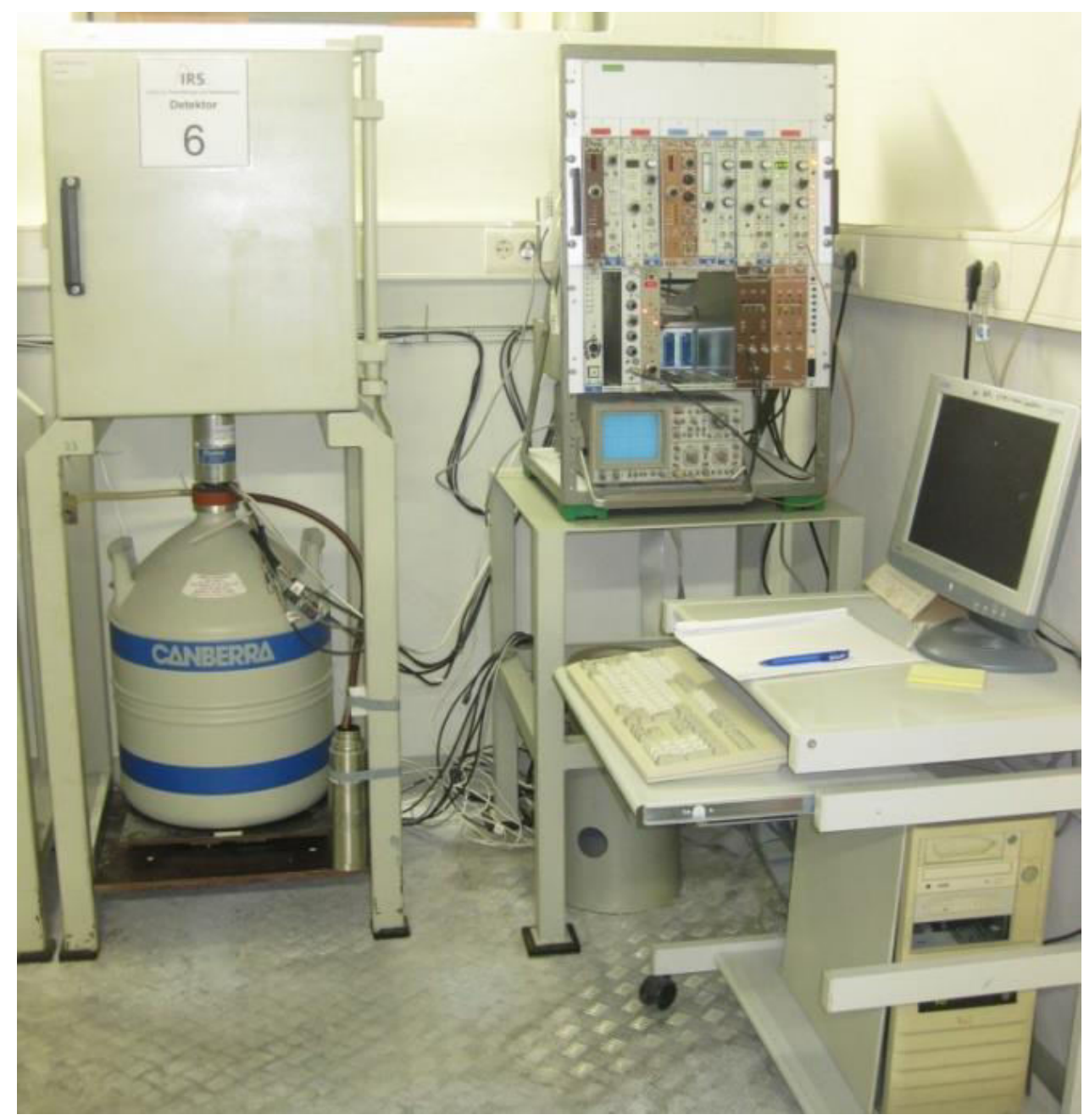

Fig.2.9: Actual setup of the experiment in our laboratory

\subsection{Detector calibration}

Since the signal output (the voltage in our case) is different from the quantity we want to measure (the photon energy), the system has to be calibrated prior to the measurement using standard samples of known composition, geometry and activity concentrations. Three types of calibration are common in gamma spectroscopy measurements, namely calibration of energy, resolution, and efficiency (Gilmore, 2008). 


\subsubsection{Energy calibration}

Energy calibration assigns a specific energy to a specific channel of the MCA. To achieve this, a source emitting gamma photons with precisely known energy is measured. It is important to have a standard source that emits energies covering the entire energy region of our sample. In this study, the QCY48 standard provided by the PTB was used as a reference standard, which contains 12 radionuclides with gamma energies ranging from $59 \mathrm{keV}$ to $1836 \mathrm{keV}$. The mathematical relationship between the channel number of the MCA and associated energy is linear to good approximation. If the channel number is denominated $C$, the associated energy $E(C)$ can be described by the following second degree polynomial function (Birkhan, 2009):

$$
E(C)=a_{0}+a_{1} * C+a_{1} * C^{2} \quad 2.4
$$

where $a_{0}$ and $a_{1}$ are energy coefficients.

\subsubsection{Resolution (FWHM) calibration}

The width of a peak at half its maximum height is called the Full Width at Half Maximum - FWHM. FWHM depends on the effectiveness of a detector in differentiating between two very close energy peaks; the term is called detector energy resolution. Calibrating the FWHM with respect to the channel number can also be described by second degree polynomial function (Knoll, 2010):

$$
\mathrm{FWHM}=\mathrm{a}_{1}+\mathrm{a}_{2} * \mathrm{C}+\mathrm{a}_{2} * \mathrm{C}^{2} \quad 2.5
$$

where $\mathrm{a}_{0}$ and $\mathrm{a}_{1}$ are curve fitting coefficients.

The detectors used in this study (detector \#3, \#4, \#5, \#6) have a resolution of $0.87,0.92$, 0.75 , and $0.85 \mathrm{keV}$ at $122 \mathrm{keV}$, and of $1.83,1.76,1.78$, and $1.80 \mathrm{keV}$ at $1.33 \mathrm{MeV}$, respectively.

\subsubsection{Efficiency calibration}

Each detector has a different response to certain energies. Therefore, it is important to know how efficient the performance of a detector at a certain point is. For this reason, the detector efficiency has also to be calibrated by using known standard sources. Measured values are fitted and result in an energy curve, which is used to find the energy efficiency 
at a certain point. There are three types of efficiency, which have to be distinguished: relative efficiency, total efficiency, and efficiency at a full peak.

The term relative efficiency is used to compare the detection probability of different detectors. The total efficiency covers all the interactions and effects taking place within the detectors, like Compton Effect and pair production, which does not deposit all of the photon energy in the detector. The full-energy peak efficiency is the measure of efficiency in a full gamma peak and will be called the efficiency hereinafter. The efficiency the ratio of the number of pulses recorded by the detector over the number of decays occurring in the sample. Efficiency can vary from detector to detector due to the difference in crystal size, dead layer and shielding. Sample size, type, density, geometry, and self-absorption also play a role. Efficiency can be written as (Tawussi, 2012):

$$
\varepsilon=\frac{D_{R}}{E_{R}} \quad 2.6
$$

where $D_{R}$ is the detected pulse rate and is the emitted pulse rate.

To calibrate the efficiency, a standard with known activity and the same geometry, density and homogeneity as that of the sample has to be used. The standard used in this study was QCY48 (see annex 1). After measuring the standard on the top and bottom of each sample, the efficiency curve is fitted using the Jäckel-Westmeier fit function (Westmeier \& Patzelt):

$$
\varepsilon(E \gamma)=\exp \left(\frac{2}{\pi}\left(a_{1}+a_{2}+a_{3} x^{2}\right) \arctan \left[\exp \left(a_{4}+a_{5}+a_{6} x^{3}\right)\right]-25\right)
$$

where the parameters $a_{1}, a_{2} \ldots a_{6}$ can be freely selected.

The resulting efficiency curve of one of the rock samples sealed gastight in a petri dish $(\mathrm{m} \sim 100 \mathrm{~g})$ is shown in Fig.2.10. 


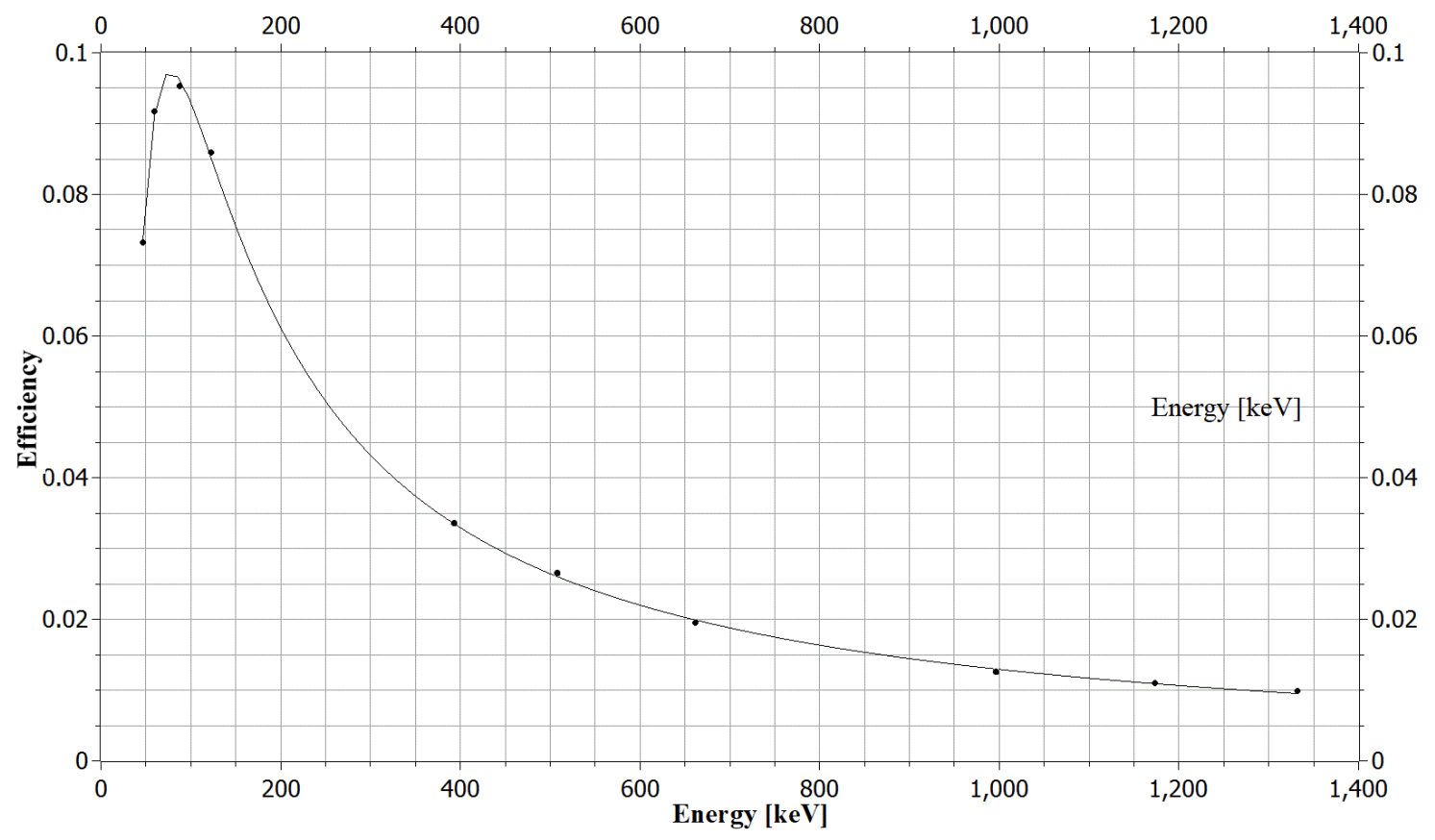

Fig.2.10: Energy efficiency calibrated and fitted to the Jäckel-Westmeier function

As shown in the figure above, the maximum efficiency is at about $120 \mathrm{keV}$. For energies higher than $120 \mathrm{keV}$, the efficiency decreases because the high energy radiation passes the detector without interaction, and for the energies lower than $120 \mathrm{keV}$ self-absorption is the dominant loss mechanism. This calibration process was repeated in the same way for all of the samples.

\subsection{Alpha spectroscopy}

In alpha decay, excited nuclei emit ${ }^{4} \mathrm{He}$ nuclei, so called alpha particles. These alpha particles do not have sufficient energy to overcome the nuclei's Coulomb barrier. but rather tunnel through the it, which is a quantum mechanical effect, (Young et al., 2016). Most $\alpha$-particles have kinetic energies between 3 and $7 \mathrm{MeV}$. The shorter the half-life, the higher is the energy of the alpha particle and vice versa (Perlman et al., 1949). As it is a charged particle, it can interact with any matter before reaching the active surface of the detector. Therefore, special preparation is needed to measure alpha emitting sources. One possible method is digestion, dissolution or leaching of the sample followed by electrodeposition on a metal plate, which was also used for the measurements of soil and rocks in this study. Because of the high energy-loss of alpha-particles in matter, even when moving through air, the measurements are carried out in vacuum. The alpha spectrometer 
used in this study was a PIPS (Passivated Implanted Planar Silicon) semiconductor detector produced by Canberra which has an active layer of up to $450 \mathrm{~mm}^{2}$. The manufacturing setup of PIPS detectors is shown in Fig.2.11 (L'Annunziata, 2012). The same electronic and output setup as of the HPGe detector with lower voltage is used for this system as well. This technique has a high detection probability and low background radiation. The $\mathrm{N}$ - doped silicon is used as detection material here to avoid the interference of the active surface of the detector with outer environment. The silicon wafer is passivated by covering it with a thin layer of oxide via a thermal process. One end of the silicon wafer is doped with P-type boron while the other end is implanted with arsenic. The whole setup around the wafer is covered by a thin layer of aluminium for mechanical protection reasons. For measuring, the prepared samples are placed on this wafer, encapsulated and placed inside the detector.

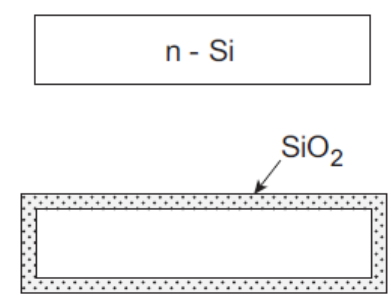

n-type Si crystal

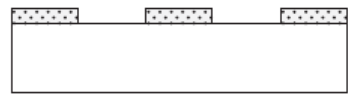

removal of oxide layer from the entrance window

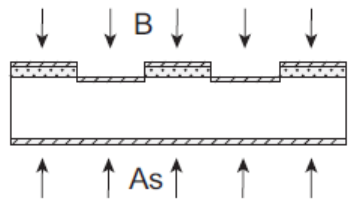

ion implantation using accelerator, doping with B p-type impurity, doping with As n-type impurity at rear side to form blocking contact

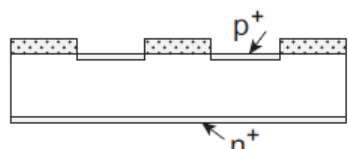

heat treatment at $600^{\circ} \mathrm{C}$,

fast cooling, removal of the non adhering layer

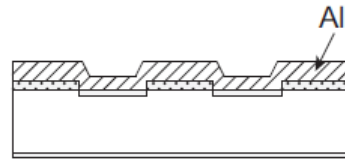

evaporation of $\mathrm{Al}$

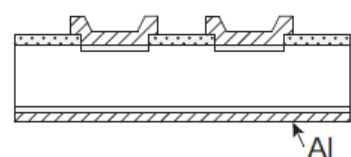

excess Al removal on front side $\mathrm{Al}$ electric contact at rear side

Fig.2.1: Steps in PIPS fabrication (Florian, 2009) 


\subsection{Radon exposure meter}

So far, several measurement techniques such as active sampling, electrostatic collection, delayed coincidence method, and alpha particle spectroscopy are used to measure the concentration of radon gas in an environment. Most of these techniques show high power consumption and the devices are not always portable.

Eight radon exposure meters recently developed by the Helmholtz Centre Munich with different calibration factors were utilized for the measurements. The devices include two silicon sensors inside the measurement chamber which have several holes covered by a filter. As the radon gas enters the chamber, the alpha particles emitted by radon progenies are recorded (Gruber et al., 2011; Irlinger et al., 2014; Karinda et al., 2008). The portable robust device has a typical sensitivity of about $3 \mathrm{cph}$ at $100 \mathrm{~Bq} / \mathrm{m} 3$, a mass of $150 \mathrm{~g}$ and a small size $(11 \mathrm{~cm} \times 6 \mathrm{~cm} \times 3 \mathrm{~cm})$ which makes it easy to carry to any remote location. The device is powered by a $3.6 \mathrm{~V}$ lithium battery; operating voltage is stabilized to $3.3 \mathrm{~V}$. An on-board cascade generator supplies a detector bias voltage of $15 \mathrm{~V}$. A fresh battery can last up to six months. The sensitivity together with the prevailing radon concentration and measurement time determines the number of recorded counts and, thus, the statistical uncertainty associated with the measurements. The electronics for this device consists of a charge sensitive amplifier, a discriminator for low energies, and a microcontroller. As the signal generated by the detector is too small, an amplifier for direct processing is necessary. Whenever the amplified signal exceeds a given threshold, a rectangular pulse is generated by the comparator. These pulses are counted by the microcontroller and stored with a timestamp.

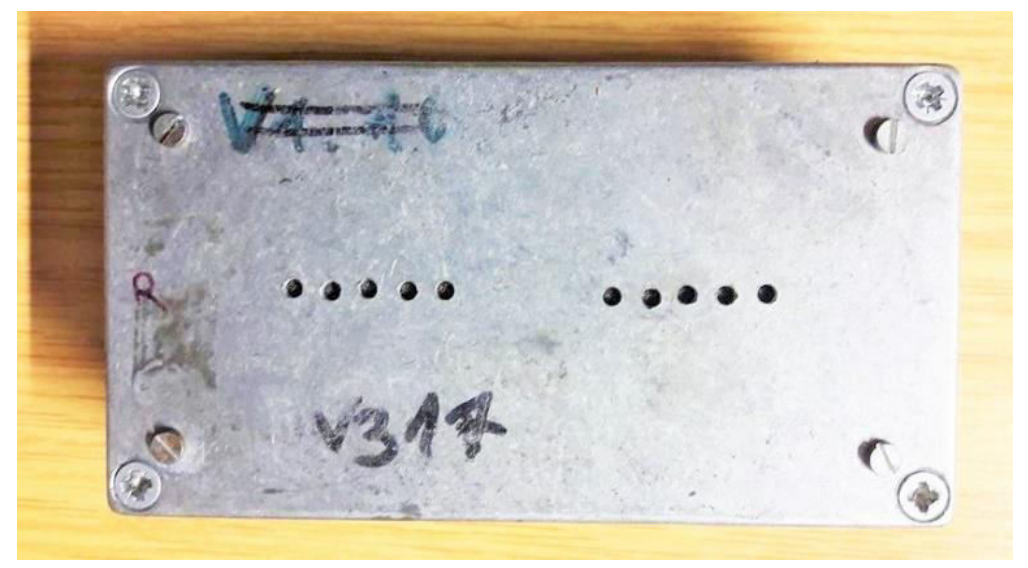

Fig.2.12: Top face of the actual device 


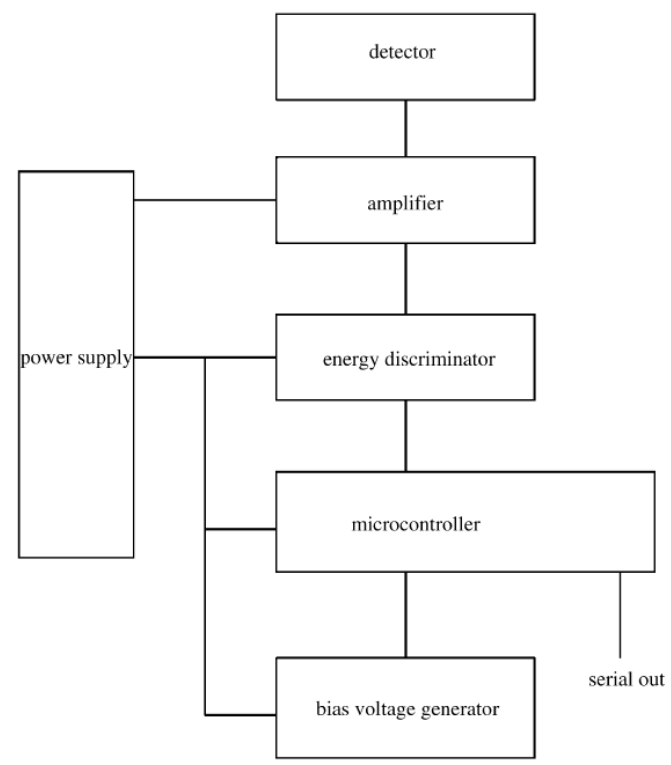

Fig.2.13: Schematic of radon meter setup.

The device was calibrated in high radon concentration environments several times before use in actual measurement sites. As the device was a prototype, the removal of battery ended the process of measurement and all of the data were erased. The data recorded by the device were transferred to the PC in ASCII format with the help of a MATLAB code or via PUTTY. A magnetic reed-switch was used to manipulate the data output.

\subsection{ICP-OES}

Inductively Coupled Plasma Optical Emission Spectrometry (ICP-OES) is an analytical technique that is used for the detection of trace elements in liquid samples. The device consists of two major parts, namely the inductively coupled plasma and the optical emission spectrometer. The sample is introduced via a peristaltic pump into a nebulizer, where it is converted to an aerosol and carried to the highly ionized argon plasma produced by the so-called torch. The torch is composed of three concentric quartz tubes surrounded by an induction coil that is powered by a radio-frequency generator. A spark from a Tesla coil initiates ionization of the flowing argon. The ions trapped in the electrical and magnetic fields collide with other argon atoms and form an argon plasma. 
The plasma atomizes the molecules and excites them to a higher state. When the excited atoms relax to the ground state they emit light. This light is the characteristic light of each element (Hölzer, 2013). The characteristic light is then directed via lenses to the OES part of the system, the different wavelengths are separated by prisms and collected by a detector placed at the end of the device. The intensity of the dispersed light as a function of wavelength (spectrum) serves an indicator of the type and concentration of the element, respectively. A standard preparation is needed before measurement. The samples are then placed into an auto sampler for the measurement. The signals detected by the detector are sent to a PC equipped by the special software of the system. Fig. 2.14 shows the schematic view of an ICP-OES.

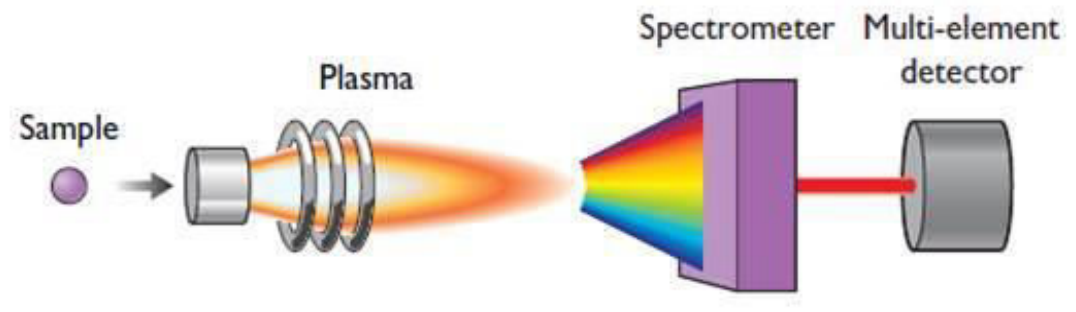

Fig.2.14: Schematic view of ICP-OES (Khushaim, 2015).

As for all the measurements systems a calibration of the system with known samples is needed, which in this case was performed by using different elements with different concentrations accordingly. The ICP-OES system used in this study is an iCAP 6200 Duo (Thermo Scientific ${ }^{\mathrm{TM}}$ ) equipped with iTeva software, Cetac ASX-260 auto sampler, Mira-Mist nebulizer, Cyclonic Spray Chamber, and 1150 W Plasma power.

\subsection{ICP-MS}

Inductively Coupled Plasma Mass Spectrometry (ICP-MS) is also an analytical technique that is used for detecting elements of very low concentration in a liquid sample. The ICP part is almost the same as for ICP-OES, but detection of the ions is accomplished by mass spectrometry (MS). The ICP part converts the atoms of the elements in the sample to ions, which are separated and detected by the mass spectrometer. The argon is discharged at a temperature of about $6000-10000^{\circ} \mathrm{K}$ which makes it an optimal positive ion source, elements forming negative ions are not very likely to be detected by ICP-MS (Nelms, 2005). 
The produced ions are transferred into the mass spectrometer by interface cones. The ion beam is focused on the quadrupole entrance region using a single or group of lenses, the ion beam then passes through a charged metallic cylinder, a magnetic field is applied on to the cylinder to deflect the incoming charges. The path it follows is proportional to the mass, thus the mass-to-charge ratio is the identification characteristic of each element. Several dynodes at the end of the metallic cylinder amplifies the incoming current and finally the signal is sent to the computer equipped with the software.

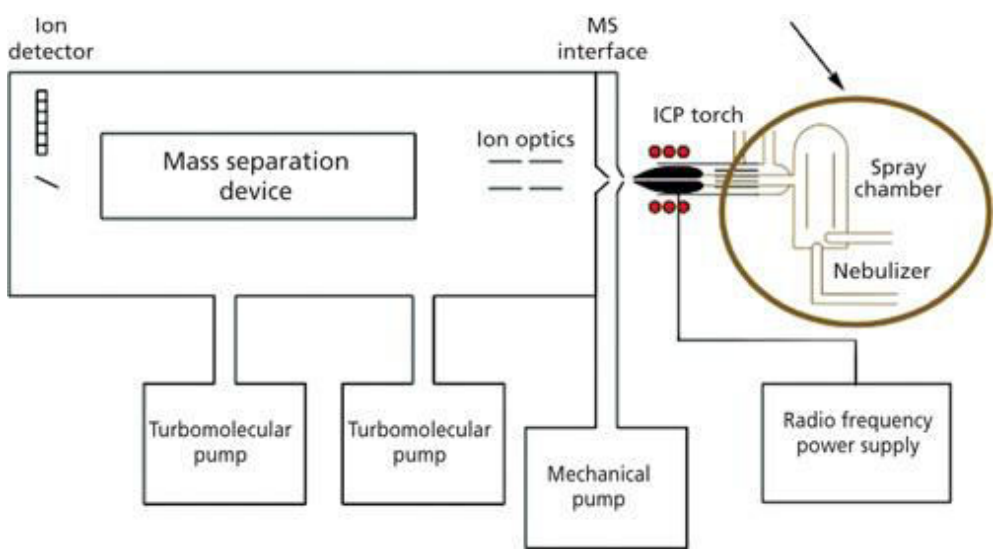

Fig.2.15: Schematic view of the major parts of an ICP-MS (Brennan et al., 2015).

ICP-MS has a lower background noise, and much lower detection limit (Thompson et al., 2008). Than ICP-OES. Under optimal conditions, the ICP-MS can detect concentrations as low as one part in $10^{15}$ or part per quadrillion (ppq).

The ICP-MS system used in this study was an iCAP Q produced (Thermo Scientific ${ }^{\mathrm{TM}}$ ) equipped with a Cetac ASX-520 auto sampler, a concentric nebulizer, and $1550 \mathrm{~W}$ Plasma power.

\subsection{X-ray fluorescence (XRF)}

$\mathrm{X}$-rays, characterized by their energies in $\mathrm{keV}$ or their wavelengths in nanometre, form the part of the electromagnetic spectrum between UV and gamma radiation. X-ray fluorescence (XRF) devices use the characteristic X-rays of an element to determine its qualitative and quantitative abundance in samples. XRF is a non-destructive technique which can measure elements of a wide range namely from sodium to uranium, in concentrations down to ppm in all liquid, solid and powder forms (Croudace \& Rothwell, 2015). All $\mathrm{XRF}$ devices are constructed from two major components, namely an X-ray source and a 
detector. The primary X-rays from the sources are directed onto the sample surface. Hitting the samples, they excite the atoms, which causes an ejection of electrons and secondary X-rays. The energy of these secondary X-rays is characteristic for the element in the sample. X-rays are detected in a detector, from where a signal is transferred to a PC. The result after conversion of the signal is a plot showing the intensity of the incident X-rays as a function of the energy of the X-ray. The energy is a qualitative indicator, while the intensity is a quantitative indicator. In comparison to other techniques, XRF is fast, nondestructive, covers a wide range of elements, requires almost no sample preparation, and is considered to be very low cost and robust.

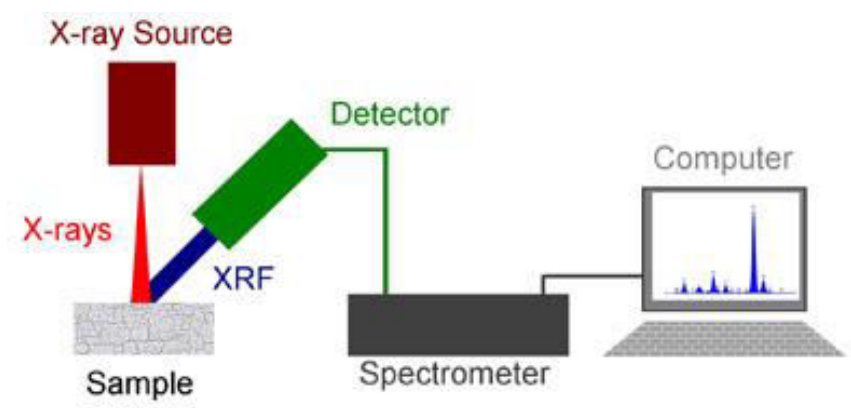

Fig.2.16: Schematic of the major parts of a XRF system (POL, 2016).

The XRF system used in this study was a Micro-XRF with high spatial resolution and the following speciation:

Tube current

Tube voltage

Spot size

Measurement time
$230 \mathrm{~mA}(\sim 30 \%$ dead time and $5000 \mathrm{cps})$

$40 \mathrm{kV}$

$50 \mu \mathrm{m}$

$2000 \mathrm{~ms}, 5000 \mathrm{~ms}$

\subsection{X-ray diffraction (XRD)}

$\mathrm{XRD}$ is the name of an analytical technique which determines crystallographic density and crystal structure of crystalline solids. In this technique an incident X-ray from an Xray source is directed on a crystalloid structure, where X-rays are diffracted at an angle $\Theta$ 
by internal crystal planes which are separated by distance $d$ from each other. This diffraction from constructive wave interference is called the Bragg's diffraction. According to Bragg's equation, the wavelength of the incident X-ray should be (Birkholz et al., 2006):

$$
\mathrm{n} \lambda=2 \mathrm{~d} \sin \theta \quad 2.7
$$

The Bragg's interference is shown in the following figure:

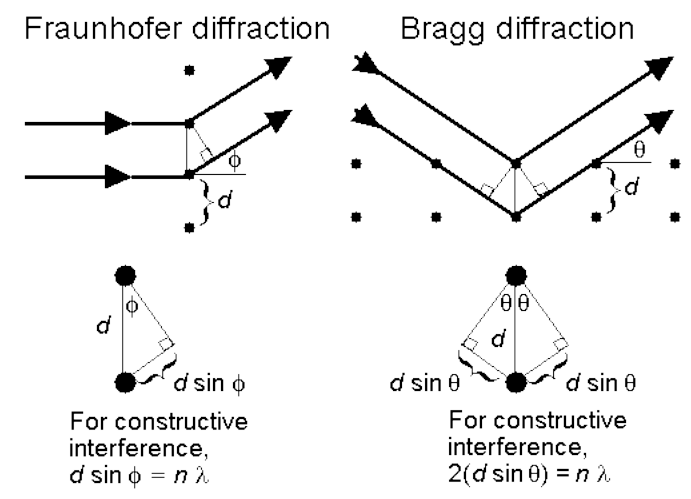

Fig.2.17: Bragg's interference.

An XRD system has three major components: an X-ray source, a sample holder, and a detector. The X-ray part is attached to tungsten for X-ray production, and the detector is attached to an output device or PC. A small amount of fine powder containing crystalline material is placed at random angels to the incident X-rays. Just by coincidence, some of these crystals are oriented so that the angle between the incidents X-rays, the powder samples and the detector meets the Bragg's condition. From each crystal meeting Bragg's condition a signal or spike is produced. To let as much crystals as possible meet the Bragg's condition the detector is rotated around the sample. For an XRD it is always necessary to have the sample as homogenous fine powder (Skoog, 2016).

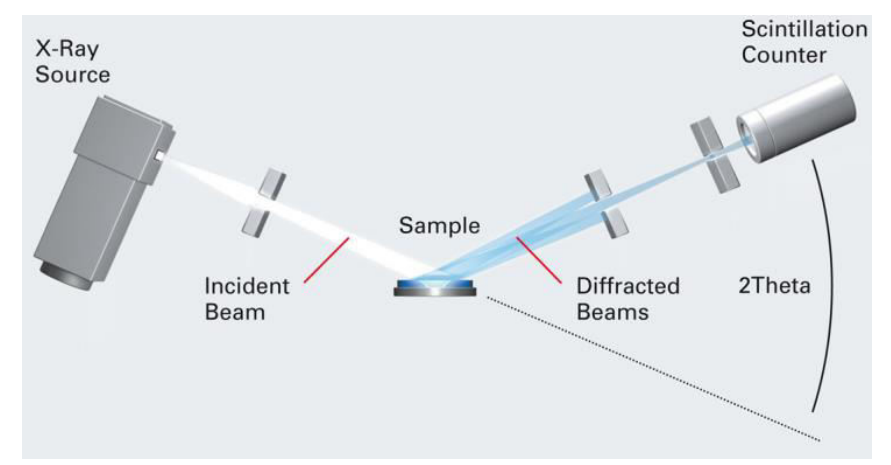

Fig.2.18: Schematic of the major parts of an XRD system (Bruker, 2017). 


\subsection{Scanning Electron Microscopy (SEM)}

SEM is one of the two major methods known in electron microscopy, this method has a similar detection principal as optical microscopy, while the difference is in creation of images based on interaction of electrons with the surface of material. In this detection technique, the electrons extracted from a source such as field emission gun is accelerated within an energy range of $0.2 \mathrm{kV}$ to $30 \mathrm{kV}$. The beam is focused to form a fine probe using magnetic and electrostatic lenses, it is then scanned over the surface area of the sample (Weiß, 2015).

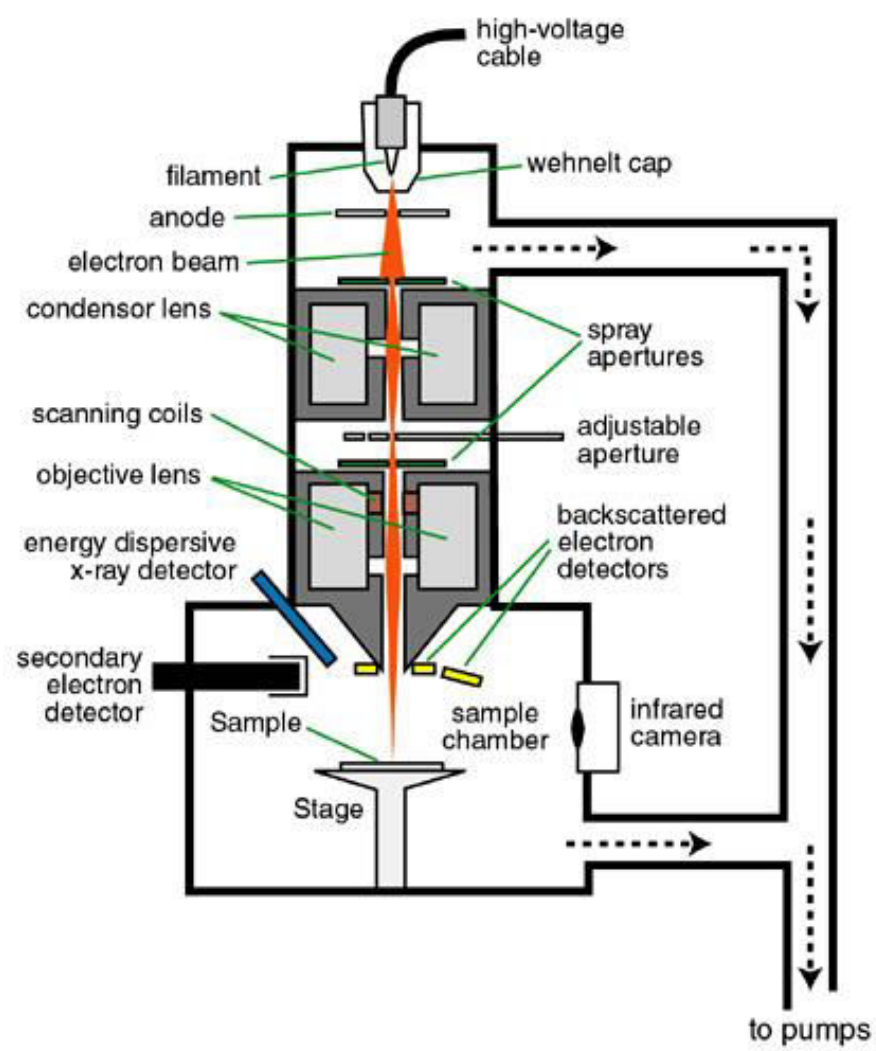

Fig. 2.19 Principle setup of a SEM instrument. An electron beam is accelerated, focused by magnetic and electrostatic lenses and then scanned over a surface area (Northern Arizona University, 2017).

There exist two major detection mode in this equipment namely secondary electron imaging SE and backscattered electron imaging BSE, where the second mode was used in this study. The main purpose of using this mode was the advantage of having a material contrast, the heavier the element the brighter the image is, this makes the uranium and thorium containing particle easily visible. 


\subsection{Energy Dispersive X-Ray Analysis (EDX)}

EDX is an analytical method that is usually included in electro microscopic setups. In this method the x-ray photons emitted as a result of the electron excitations of the atoms are detected. As shown in Fig 2.20, an accelerated electron beam transfers its energy to an electron in low energy level of the atomic shell, the electrons become excited, upon relaxation the energy difference is emitted in form of an x-ray photon. The energy of this photon is the characteristic of each element in the sample. Fig. 2.20 shows the basic mechanism of an EDX Analysis where electrons are excited by an external energy source and leave the atomic shell. As an electron beam is often used as the excitation source, therefore an EDX detector is built with a SEM system. Since the electron beam is scans over the surface, elemental mapping of the sample is made possible (Weiß, 2015).

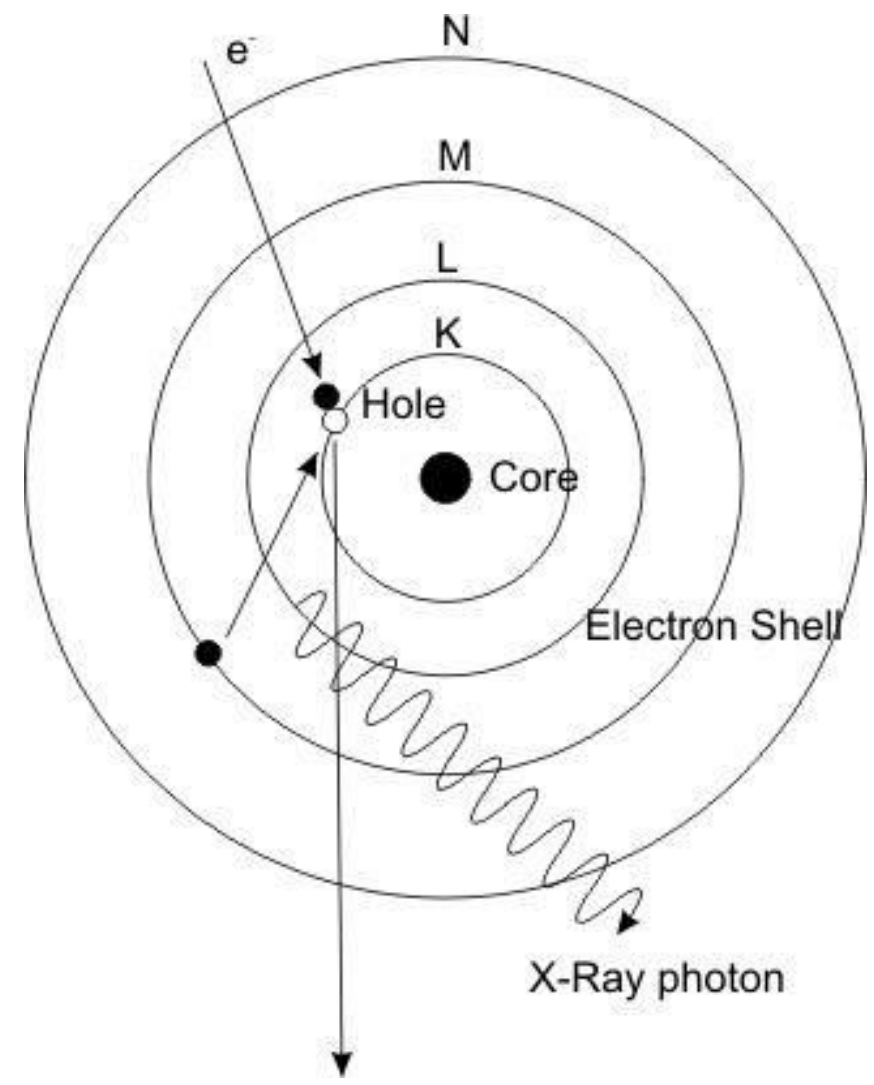

Fig. 2.20 sketch of the basic mechanism of an EDX analysis (Global Sino, 2017) 


\section{Chapter}

\section{Sampling, preparation and measurement}

\subsection{Rock and soil}

\subsubsection{Rock and soil samples collection}

To verify the existing information and claims on the presence of artificial radionuclides as well as origin of high level of radiation in the residential areas near Kabul, the Afghan Atomic Energy High Commission (AAEHC) in collaboration with Afghan Geology Survey (AGS) launched a sample collection campaign, which yielded 51 rock and soil samples from Kabul suburbs. The samples were shipped to the Institute for Radioecology and Radiation Protection (IRS) of the Leibniz Universität Hannover for further analysis. One soil and fifty rock samples were collected in three phases between January 2014 and October 2015. In the first phase, one soil and four rock samples were collected from two sampling spots in January and February 2014, in the second phase (October 2014) twenty rock samples were collected from two sampling sites, and in third phase (October 2015) twenty-six samples were collected from two different sampling sites. The sampling sites are shown in Fig.3.1; the sampling sites are marked with red stars. Due to the presence of residential houses built on the radiation emitting rocks, some of the planned sampling sites could not be accessed. The background count rates of these sites were monitored by a RedEye Personal Radiation Detector (PRD) $100 \mathrm{~cm}$ above ground. Rock samples had a weight of about $100 \mathrm{~g}$ each. The GPS coordinates, names of sampling locations, sample weights, background radiation, and measurement dates of the samples are given in table 3.1 . 


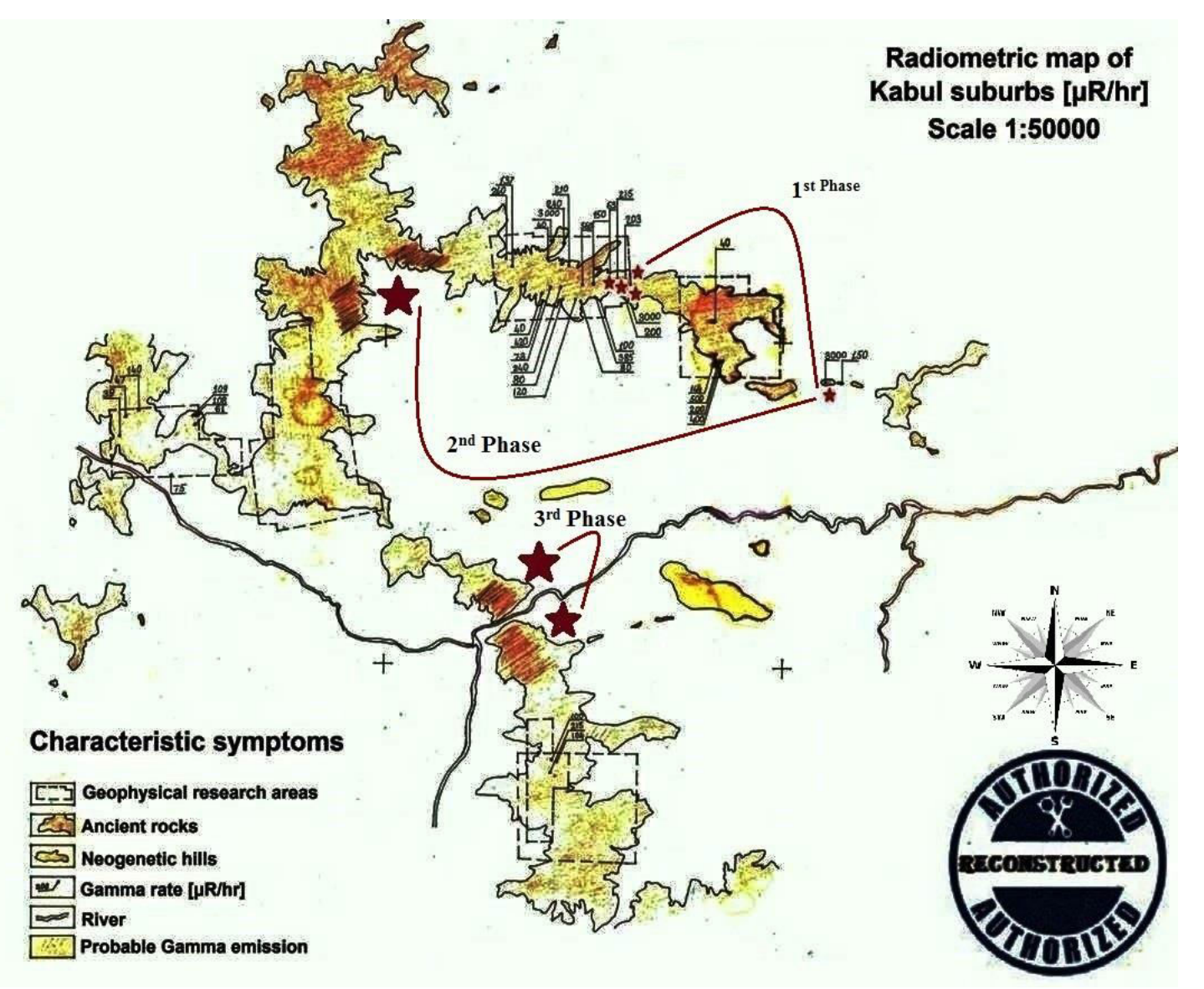

Fig.3.1 Authorized reconstructed map from the 1980s, hand drawn by the joint Russian and Afghan survey team. Sampling sites are marked with stars. 
Table 3.1. Data and coordinates of samples and sampling sites.

\begin{tabular}{|c|c|c|c|c|c|c|}
\hline Phase & $\begin{array}{c}\text { Sample type and num- } \\
\text { ber }\end{array}$ & $\begin{array}{c}\text { Background } \\
{[\mathrm{c} / \mathrm{sec}]}\end{array}$ & Sampling site & $\begin{array}{c}\text { GPS coordi- } \\
\text { nates }\end{array}$ & $\begin{array}{c}\text { Weight } \\
{[\mathrm{g}]}\end{array}$ & $\begin{array}{c}\text { Measurement } \\
\text { date }\end{array}$ \\
\hline \multirow{5}{*}{ 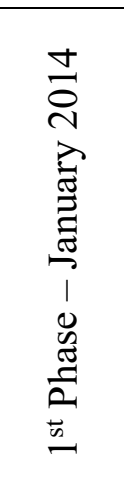 } & Rock 1 & $\sim 50$ & Alikhail Hills Deh sabz distrect & $\begin{array}{l}\mathrm{N} 34.57243^{0} \\
\text { E } 69.26254^{0}\end{array}$ & 110.5 & $7 / 2 / 2014$ \\
\hline & Rock 2 & $\sim 50$ & Khawja Rawash Khair Khana & $\begin{array}{l}\text { N } 34.59268^{0} \\
\text { E } 69.20026^{0}\end{array}$ & 118 & $7 / 24 / 2014$ \\
\hline & Rock 3 & $\sim 50$ & Khawja Rawash Khair Khana & $\begin{array}{l}\text { N } 34.59306^{0} \\
\text { E } 69.19986^{0}\end{array}$ & 147.6 & $7 / 28 / 2014$ \\
\hline & Rock 4 & $\sim 50$ & Khawja Rawash Khair Khana & $\begin{array}{l}\mathrm{N} 34.57244^{0} \\
\text { E } 69.26255^{0}\end{array}$ & 172.5 & $7 / 14 / 2014$ \\
\hline & Soil 5 & $\sim 50$ & Alikhail Hills Deh sabz distrect & $\begin{array}{l}\text { N } 34.57242^{0} \\
\text { E } 69.26253^{0}\end{array}$ & 43.2 & $7 / 14 / 2014$ \\
\hline \multirow{7}{*}{ 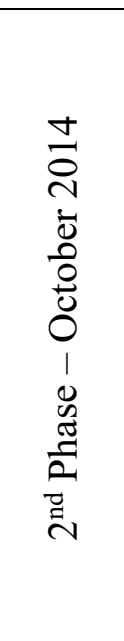 } & Rock 1 & $\sim 50$ & Daf-e-hawa hills & $\begin{array}{l}\text { N } 34.34161^{0} \\
\text { E } 69.16236^{0}\end{array}$ & 103.84 & $6 / 4 / 2015$ \\
\hline & Rock 2 & $\sim 45$ & Daf-e-hawa hills & $\begin{array}{l}\mathrm{N} 34.34164^{0} \\
\text { E } 69.16252^{0}\end{array}$ & 91.29 & $3 / 26 / 2015$ \\
\hline & Rock 3 & $\sim 45$ & Daf-e-hawa hills & $\begin{array}{l}\text { N } 34.34208^{0} \\
\text { E } 69.15451^{0}\end{array}$ & 94.06 & $6 / 5 / 2015$ \\
\hline & Rock 4 & $\sim 40$ & Qasaba hills & $\begin{array}{c}\mathrm{N} 34.35335^{0} \\
\text { E } 69.1214^{0}\end{array}$ & 152.08 & $3 / 27 / 2015$ \\
\hline & Rock 5 & $\sim 40$ & Qasaba hills & $\begin{array}{c}\mathrm{N} 34.35337^{0} \\
\mathrm{E} 69.1212^{0}\end{array}$ & 101.05 & $6 / 5 / 2015$ \\
\hline & Rock 6 & $\sim 40$ & Qasaba hills & $\begin{array}{l}\text { N } 34.35349^{0} \\
\text { E } 69.11594^{0}\end{array}$ & 93.66 & $6 / 5 / 2015$ \\
\hline & Rock 7 & $\sim 40$ & Alli khail hills & $\mathrm{N} 34.3685^{0}$ & 85.98 & $6 / 8 / 2015$ \\
\hline
\end{tabular}




\begin{tabular}{|c|c|c|c|c|c|}
\hline & & & E $69.11374^{0}$ & & \\
\hline Rock 8 & $\sim 40$ & Qasaba hills & $\begin{array}{l}\mathrm{N} 34.35351^{0} \\
\mathrm{E} 69.11596^{0}\end{array}$ & 141.46 & $3 / 30 / 2015$ \\
\hline Rock 9 & $\sim 40$ & Qasaba hills & $\begin{array}{l}\text { N } 34.35353^{0} \\
\text { E } 69.11598^{0}\end{array}$ & 165.17 & $3 / 31 / 2015$ \\
\hline Rock 10 & $\sim 40$ & Qasaba hills 315 Army base & $\begin{array}{l}\mathrm{N} 34.35335^{0} \\
\mathrm{E} 69.12016^{0}\end{array}$ & 117.96 & $8 / 6 / 2015$ \\
\hline Rock 11 & $\sim 40$ & Qasaba hills 315 Army base & $\begin{array}{l}\text { N } 34.35351^{0} \\
\text { E } 69.11594^{0}\end{array}$ & 94.08 & $4 / 7 / 2015$ \\
\hline Rock 12 & $\sim 40$ & Qasaba hills 315 Army base & $\begin{array}{l}\text { N } 34.35349^{0} \\
\text { E } 69.11595^{0}\end{array}$ & 91.67 & $9 / 6 / 2015$ \\
\hline Rock 13 & $\sim 40$ & Qasaba hills 315 Army base & $\begin{array}{l}\text { N } 34.35357^{0} \\
\text { E } 69.11597^{0}\end{array}$ & 100.73 & $4 / 8 / 2015$ \\
\hline Rock 14 & $\sim 40$ & Ali Khail deh sabz & $\begin{array}{l}\text { N } 34.34207^{0} \\
\text { E } 69.15451^{0}\end{array}$ & 99.32 & $3 / 28 / 2015$ \\
\hline Rock 15 & $\sim 40$ & Ali Khail deh sabz & $\begin{array}{l}\mathrm{N} 34.33093^{0} \\
\mathrm{E} 69.02350^{0}\end{array}$ & 102.07 & $6 / 6 / 2015$ \\
\hline Rock 16 & $\sim 40$ & Qasaba hills 315 Army base & $\begin{array}{l}\text { N } 34.35352^{0} \\
\text { E } 69.11594^{0}\end{array}$ & 95.78 & $4 / 9 / 2015$ \\
\hline Rock 17 & $\sim 40$ & Ali Khail deh sabz & $\begin{array}{l}\text { N } 34.34205^{0} \\
\text { E } 69.15449^{0}\end{array}$ & 94.38 & $10 / 6 / 2015$ \\
\hline Rock 18 & $\sim 40$ & Qasaba hills & $\begin{array}{l}\text { N } 34.35352^{0} \\
\text { E } 69.11596^{0} \\
\end{array}$ & 151.3 & $4 / 10 / 2015$ \\
\hline Rock 19 & $\sim 40$ & Qasaba hills & $\begin{array}{l}\text { N } 34.35350^{0} \\
\text { E } 69.11591^{0}\end{array}$ & 95.03 & $10 / 6 / 2015$ \\
\hline Rock 20 & $\sim 40$ & Qasaba hills & $\begin{array}{l}\text { N } 34.35349^{0} \\
\text { E } 69.11591^{0}\end{array}$ & 150.88 & $4 / 13 / 2015$ \\
\hline
\end{tabular}




\begin{tabular}{|c|c|c|c|c|c|c|}
\hline \multirow{14}{*}{ 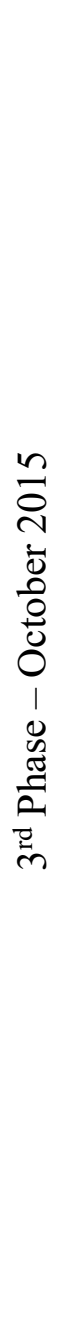 } & Rock 1 & $\sim 45$ & Koh-e-Asmai (Front lower right) & $\begin{array}{l}\text { N } 34.525105 \\
\text { E } 69.151523\end{array}$ & 108.44 & $3 / 7 / 2016$ \\
\hline & Rock 2 & $\sim 45$ & Koh-e-Asmai (Front Lower right) & $\begin{array}{l}\text { N } 34.525083^{0} \\
\text { E } 69.151602^{0}\end{array}$ & 105.69 & $3 / 8 / 2016$ \\
\hline & Rock 3 & $\sim 50$ & Koh-e-Asmai (Front lower right) & $\begin{array}{l}\text { N } 34.525131^{0} \\
\text { E } 69.151777^{0}\end{array}$ & 103.44 & $3 / 14 / 2016$ \\
\hline & Rock 4 & $\sim 40$ & Koh-e-Asmai (Front lower middle) & $\begin{array}{l}\text { N } 34.525212^{0} \\
\text { E } 69.152060^{0}\end{array}$ & 114.93 & $3 / 15 / 2016$ \\
\hline & Rock 5 & $\sim 40$ & Koh-e-Asmai (Front lower middle) & $\begin{array}{l}\text { N } 34.525231^{0} \\
\text { E } 69.152231^{0}\end{array}$ & 106.42 & $3 / 16 / 2016$ \\
\hline & Rock 6 & $\sim 40$ & Koh-e-Asmai (Front lower middle) & $\begin{array}{l}\text { N } 34.525269^{0} \\
\text { E } 69.152425^{0}\end{array}$ & 105.42 & $3 / 17 / 2016$ \\
\hline & Rock 7 & $\sim 40$ & Koh-e-Asmai (Front lower left) & $\begin{array}{l}\text { N } 34.525331^{0} \\
\text { E } 69.152885^{0}\end{array}$ & 107.73 & $3 / 18 / 2016$ \\
\hline & Rock 8 & $\sim 40$ & Koh-e-Asmai (Front lower left) & $\begin{array}{l}\text { N } 34.525336^{0} \\
\text { E } 69.153052^{0}\end{array}$ & 107.33 & $3 / 21 / 2016$ \\
\hline & Rock 9 & $\sim 40$ & Koh-e-Asmai (Front lower left) & $\begin{array}{l}\text { N } 34.525317^{0} \\
\text { E } 69.153156^{0}\end{array}$ & 104.1 & $3 / 21 / 2016$ \\
\hline & Rock 10 & $\sim 40$ & Koh-e-Asmai (Front lower edge) & $\begin{array}{l}\text { N } 34.525085^{0} \\
\text { E } 69.153425^{0}\end{array}$ & 114.41 & $3 / 22 / 2016$ \\
\hline & Rock 11 & $\sim 40$ & Koh-e-Asmai (Front upper edge) & $\begin{array}{l}\text { N } 34.525076^{0} \\
\text { E } 69.153328^{0}\end{array}$ & 109.22 & $3 / 23 / 2016$ \\
\hline & Rock 12 & $\sim 40$ & Koh-e-Asmai(Front upper left) & $\begin{array}{l}\text { N } 34.525093^{0} \\
\text { E } 69.152969^{0}\end{array}$ & 104.46 & $3 / 23 / 2016$ \\
\hline & Rock 13 & $\sim 40$ & Koh-e-Asmai(Front upper middle) & $\begin{array}{l}\text { N } 34.524957^{0} \\
\text { E } 69.152449^{0}\end{array}$ & 114.47 & $3 / 24 / 2016$ \\
\hline & Rock 14 & $\sim 40$ & Koh-e-Asmai (Front upper right) & N $34.524778^{0}$ & 107.1 & $3 / 24 / 2016$ \\
\hline
\end{tabular}




\begin{tabular}{|c|c|c|c|c|c|}
\hline & & & E $69.152135^{0}$ & & \\
\hline Rock 15 & $\sim 40$ & Koh-e-Asmai (Back upper right) & $\begin{array}{l}\text { N } 34.524697^{0} \\
\text { E } 69.152006^{0}\end{array}$ & 107.64 & $3 / 29 / 2016$ \\
\hline Rock 16 & $\sim 40$ & Koh-e-Asmai (Back upper middle) & $\begin{array}{l}\text { N } 34.524464^{0} \\
\text { E } 69.151723^{0}\end{array}$ & 106.43 & $3 / 29 / 2016$ \\
\hline Rock 17 & $\sim 40$ & Koh-e-Asmai (Back upper left) & $\begin{array}{l}\text { N } 34.524164^{0} \\
\text { E } 69.151453^{0}\end{array}$ & 111.02 & $3 / 30 / 2016$ \\
\hline Rock 18 & $\sim 40$ & Koh-e-Asmai (Back lower right) & $\begin{array}{l}\text { N } 34.523960^{0} \\
\text { E } 69.150879^{0}\end{array}$ & 111.85 & $3 / 30 / 2016$ \\
\hline Rock 19 & $\sim 40$ & Koh-e-Asmai (Back lower middle) & $\begin{array}{l}\text { N } 34.523951^{0} \\
\text { E } 69.149862^{0}\end{array}$ & 112.91 & $3 / 31 / 2016$ \\
\hline Rock 20 & $\sim 40$ & Koh-e-Asmai (Back lower left) & $\begin{array}{l}\text { N } 34.523648^{0} \\
\text { E } 69.147780^{\circ}\end{array}$ & 105.01 & $3 / 31 / 2016$ \\
\hline Rock 21 & $\sim 40$ & Koh-e-Sher Darwazah (Front lower right) & $\begin{array}{l}\mathrm{N} 34.509712^{0} \\
\text { E } 69.164546^{0}\end{array}$ & 106 & $4 / 1 / 2016$ \\
\hline Rock 22 & $\sim 40$ & $\begin{array}{l}\text { Koh-e-Sher Darwazah (Front lower mid- } \\
\text { dle) }\end{array}$ & $\begin{array}{l}\text { N } 34.509361^{0} \\
\text { E } 69.164596^{0}\end{array}$ & 106.69 & $4 / 4 / 2016$ \\
\hline Rock 23 & $\sim 40$ & Koh-e-Sher Darwazah (Front lower left) & $\begin{array}{l}\text { N } 34.509569^{0} \\
\text { E } 69.163939^{0}\end{array}$ & 104.29 & $4 / 4 / 2016$ \\
\hline Rock 24 & $\sim 40$ & Koh-e-Sher Darwazah (Front upper left) & $\begin{array}{l}\text { N } 34.509009^{0} \\
\text { E } 69.163946^{0}\end{array}$ & 110.67 & $4 / 5 / 2016$ \\
\hline Rock 25 & $\sim 40$ & Koh-e-Sher Darwazah (Front upper left) & $\begin{array}{l}\text { N } 34.509177^{0} \\
\text { E } 69.163680^{0}\end{array}$ & 105.36 & $4 / 5 / 2016$ \\
\hline Rock 26 & $\sim 40$ & Koh-e-Sher Darwazah (Front lower left) & $\begin{array}{l}\text { N } 34.508967^{0} \\
\text { E } 69.163729^{0}\end{array}$ & 107.85 & $4 / 6 / 2016$ \\
\hline
\end{tabular}




\subsubsection{Sample preparation and measurement}

Rock and soil samples were collected from the surface with each sampling site covering an area of around $100 \mathrm{~m}^{2}$, and were packed in polythene bags. After shipment to IRS, samples were smashed, milled, sealed gas-tight in Marinelli beakers, and stored for one month to attain radioactive equilibrium of the mother and daughter nuclei of the decay chains.

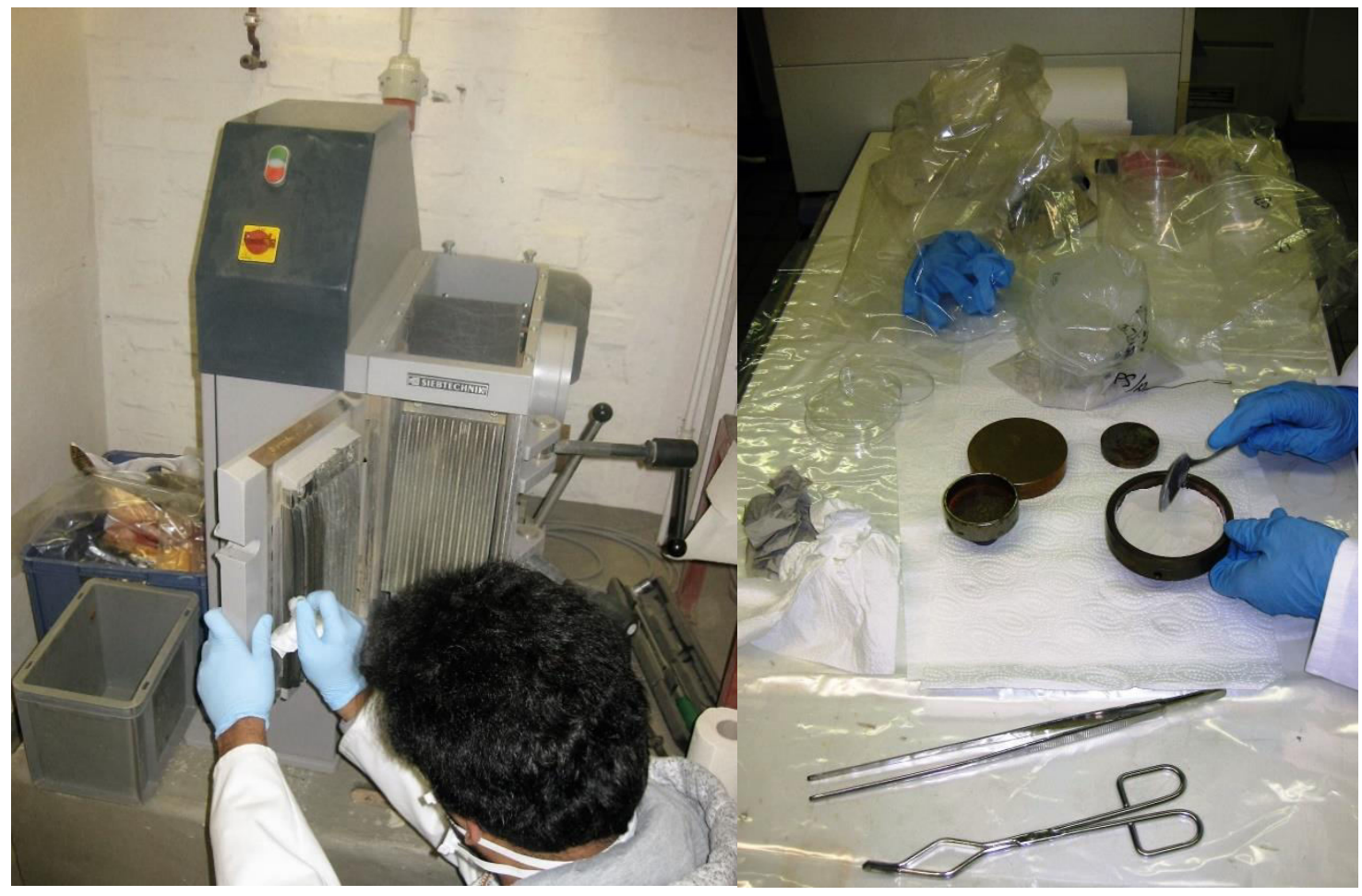

Fig.3.2. Crusher unit (left) and packing of the milled samples into petri dishes (right)

\subsubsection{Gamma spectroscopy}

All samples were measured by High Purity Germanium (HPGe) gamma ray spectrometry systems. The four detectors used were an Ortec planar detector (number 3; 42.1\% relative efficiency), a Canberra n-type coaxial detector (number $4 ; 28.3 \%$ relative efficiency), a Canberra n-type planar detector (number $5 ; 33.1 \%$ relative efficiency), and a Canberra p-type coaxial detector (number $6 ; 35.0 \%$ relative efficiency). All of the detector systems have a resolution between $1.76 \mathrm{keV}$ and $1.83 \mathrm{keV}$ for the $1.33 \mathrm{MeV}$ photo peak of ${ }^{60} \mathrm{Co}$. They are connected to a $16 \mathrm{k}$ multi-channel analyzer s(MCA), operated with Maestro II software installed on DOS operating systems for the spectrum analysis. All systems are shielded in order to reduce the influence of background and backscattered radiation. Data 
were collected in time intervals ranging from 24 to 98 hours for different samples. The energy range covered $46-2000 \mathrm{keV}$, the efficiency of the detectors was measured using a multi element standard (QCY 48) and a ${ }^{210} \mathrm{~Pb}$ standard sample as reference sources applying the same geometry as used for the rock sample measurements (Eckert \& Ziegler Nuclitec Gmbh). FitzPeaks and QtiPlot software were used for offline analysis of the collected data and fitting of the calibration line distribution, respectively. The most probable peaks not appearing in the analysis were inserted and fitted manually. The background was measured under comparable conditions and was later subtracted from the measured values.

For a sufficiently old, undisturbed system, all members of the three natural decay chains should be in secular radioactive equilibrium. For a system not in total equilibrium, at least short lived daughter nuclides might be used, as they are fully grown in after approximately five to six half-lives of the daughters (Papadopoulos et al., 2013). Therefore, for the evaluation of long-lived and non-gamma-emitting daughters, the following gamma lines were picked out. For determination of ${ }^{238} \mathrm{U}$, the gamma line of metastable ${ }^{234 \mathrm{~m}} \mathrm{~Pa}(1001 \mathrm{keV})$ was used, while the ${ }^{214} \mathrm{~Pb}(295.2$ and $352.0 \mathrm{keV})$ and ${ }^{214} \mathrm{Bi}(1120.29 \mathrm{keV}$ and 1764.49 $\mathrm{keV}$ ) photo peaks were used for determining ${ }^{226} \mathrm{Ra}$ as ${ }^{238} \mathrm{U}$ progeny. To determine ${ }^{228} \mathrm{Ra}$ as a ${ }^{232} \mathrm{Th}$ progeny, the ${ }^{228} \mathrm{Ac}(911.20 \mathrm{keV}$ and $968.97 \mathrm{keV})$ photo peaks were used, while the ${ }^{212} \mathrm{~Pb}(238.6 \mathrm{keV})$ and ${ }^{208} \mathrm{Tl}(583.1$ and $860.56 \mathrm{keV})$ photo peaks were chosen for the ${ }^{228} \mathrm{Th}$ determination. For ${ }^{235} \mathrm{U}$ determination, the $(163.33 \mathrm{keV}$ and $205.31 \mathrm{keV})$ photo peaks were used, while the ${ }^{219} \mathrm{Rn}(401.81 \mathrm{keV})$ and ${ }^{211} \mathrm{~Pb}(404.85 \mathrm{keV})$ photo peaks were picked for determination of ${ }^{227}$ Ac. Finally, the $1460.83 \mathrm{keV}$ gamma line was chosen to determine the ${ }^{40} \mathrm{~K}$ activity concentration.

Gamma line selection was based on energy line abundance of the concerning isotope and least disturbed peaks of the daughter nuclides. The abundance of a gamma line of a particular energy, which might lead to disturbance of a peak, was taken from literature and the selection was made based on that. Nuclide identification was performed using the FitzPeaks open source gamma energies analytical software. For a better accuracy, energy lines below $100 \mathrm{keV}$ were not included in calculations.

${ }^{234 \mathrm{~m}} \mathrm{~Pa}$ has gamma lines at $766.37 \mathrm{keV}$ and $1001.03 \mathrm{keV}$, respectively, where the emission probability of the $1001.03 \mathrm{keV}$ gamma line is higher than that of the $766.37 \mathrm{keV}(0.8 \%$ 
and $0.2 \%$ for $1001.03 \mathrm{keV}$ and $766.37 \mathrm{keV}$, respectively). Additionally, the $766.37 \mathrm{keV}$ line is potentially disturbed by ${ }^{211} \mathrm{~Pb}$ with a line at $766.51 \mathrm{keV}$ (emission probability of $0.3 \%$ ). Therefore, only the $1001.03 \mathrm{keV}$ line was picked out for determination of ${ }^{238} \mathrm{U}$. Even though the line at $185.72 \mathrm{keV}$ is the most probable gamma line of ${ }^{235} \mathrm{U}$, the ${ }^{226} \mathrm{Ra}$ $186.1 \mathrm{keV}$ line increases uncertainty for its determination.

During activity calculation, the background counts were subtracted from the material measurement counts and the following formula was used to calculate the specific activity (Tawussi, 2012):

$$
\mathrm{a}=\frac{\mathrm{k}_{\mathrm{s}}}{\mathrm{m} \varepsilon \rho_{\gamma}} * \mathrm{r}_{\mathrm{n}}=\omega * \mathrm{r}_{\mathrm{n}}
$$

where $a$ is specific activity of the element, $k_{s}$ is a nuclide dependent dimensionless correction factor, $r_{n}$ is the net count, $m$ is the mass of the material, $\varepsilon$ is the efficiency, $\rho_{\gamma}$ is the emission probability of a certain isotope and $\omega$ is the calibration factor.

The uncertainty of the activity is calculated using the following formula (BIPM, 2008):

$$
u(a)=\sqrt{r_{n}^{2} * u^{2}(\omega)+\omega^{2} * u^{2}\left(r_{n}\right)}=\sqrt{a^{2} * u_{r e l}^{2}(\omega)+\omega^{2} * u^{2}\left(r_{n}\right)}
$$

where the relative uncertainty $\mathrm{u}_{\mathrm{rel}}(\omega)$ is:

$$
\mathrm{u}_{\mathrm{rel}}^{2}(\omega)=\mathrm{u}_{\mathrm{rel}}^{2}\left(\mathrm{k}_{\mathrm{s}}\right)+\mathrm{u}_{\mathrm{rel}}^{2}(\mathrm{~m})+\mathrm{u}_{\mathrm{rel}}^{2}(\varepsilon)+\mathrm{u}_{\mathrm{rel}}^{2}\left(\rho_{\gamma}\right)
$$

In order not to jump into a conclusion, but to verify the gamma spectroscopy results, four different methods were used to measure the uranium and thorium concentrations, and ${ }^{238} \mathrm{U} /{ }^{235} \mathrm{U}$ activity ratios. Furthermore, the mineralogical structure in some samples was identified.

\subsubsection{Alpha spectroscopy}

To measure the uranium and thorium isotopes by alpha-spectrometry, one soil and seven rock samples (F1R4, F1S, F2R1, F2R2, F2R9, F3R1, F3R4 and F3R20) have been investigated, with F, R and S denominating the sampling phase, rock and soil, respectively. The beforehand powdered rock and soil samples were digested by microwave pressure digestion with nitric and hydrofluoric acid at a maximum temperature of $220{ }^{\circ} \mathrm{C}$ and a 
maximum pressure of 120 bar. Uranium and thorium were separated by solid-phase extraction using UTEVA-cartridges (Eichrom Technologies. Inc, 2013). Following the established separation procedure (Bister et al., 2010), uranium and thorium were electrodeposited separately onto stainless steel planchets using the method described in Eichrom working instruction (Eichrom Technologies. Inc, 2001). Alpha-spectrometry measurements of the samples were performed using a Model 7200 Alpha Analyst Integrated Alpha Spectrometer equipped with PIPS-detectors.

\subsubsection{TOF-SIMS}

A small amount of the powdered soil sample from the first phase of sampling was pressed on a thin indium foil and covered with an alpha track detector (CN-85, Kodak). After 33 days of exposure, the detector was etched with $10 \% \mathrm{NaOH}$ at $60^{\circ} \mathrm{C}$ for $20 \mathrm{~min}$ and rinsed with deionized water. The analysis of the detector with an optical microscope (Eclipse LV-DAF, Nikon) shows a very high amount of heterogeneously distributed spots produced by alpha radiation emitting particles.

A part of the sample, on which many particles were located, was cut out and analysed with a Time-of-Flight Secondary Ion Mass Spectrometer (TOF-SIMS 5, ION-TOF GmbH, software Surface Lab 6.5). This device scans sample surfaces with primary bismuth ions with $30 \mathrm{kV}$ acceleration voltage.

\subsubsection{4 $\mu-X R F$}

To obtain qualitative and semi-quantitative information a total of 15 samples (sample number 1 to 5 from each of the three sampling phases) were analysed using Micro X-ray Fluorescence spectroscopy $(\mu-X R F)$. An Eagle $\mu$-Probe II (EDAX, Software: Eday-Vision32, Version 3.999) with Rh-target and $\mathrm{Si}(\mathrm{Li})$-detector was used, adjusted to a spot diameter of $50 \mu \mathrm{m}, 40 \mathrm{keV}$ voltage, and vacuum conditions for all analyses. The beforehand prepared sample carriers were fixed in the sample chamber using adhesive tape in order to prevent displacement during analysis. Three spot measurements were performed for each sample using 210-370 mA current, $100 \mathrm{sec}$ measurement time, and $17 \mu \mathrm{s}$ amplifier shaping time. The quantification was based on a fundamental parameter model (FundParam-Version 35), normalizing the quantified elements to $100 \%$. Additionally, for two samples elemental mappings were generated by $\mu$-XRF to locate uraniferous particles 
(current: 230-320 mA; amplitude time: $10 \mu \mathrm{s}$; matrix: 64x50; 128x100; measurement time per spot: $2000 \mathrm{~ms}, 5000 \mathrm{~ms}$; spot distance: 42-73 $\mu \mathrm{m})$. Sixteen elements were mapped simultaneously (MgK, AlK, SiK, RhL, PdL, K, CaK, TiK, CrK, MnK, FeK, CoK, CuK, RaL, ThL, UL).

\subsubsection{PXRD}

Based on $\mu$-XRF information, a total of 15 samples (sample number 1 to 5 from each of the three sampling phases) were analysed by powder X-ray diffraction (PXRD) to identify the mineralogical composition of the samples. The measurements were performed using a Rigaku MiniFlex 600 diffractometer equipped with a $\mathrm{Cu} \mathrm{K} \alpha$ radiation $(\lambda=1.54056 \AA$, $40 \mathrm{kV} / 15 \mathrm{~mA}$ operation) X-ray source and a D/Tex Ultra Si strip detector with a standard detection mode.

The samples (approximately $100 \mathrm{mg}$ ) were powdered prior to the measurements, and were placed on a zero-background Si sample holder of $10.0 \mathrm{~mm}$ diameter and $0.2 \mathrm{~mm}$ depth. In order to minimize the effect of "preferred orientation" on the acquired diffractogram, the sample holder was constantly rotated horizontally during the measurement. The samples were analysed under ambient conditions, diffractograms were recorded from $5^{\circ}$ to $80^{\circ}$ with $0.02^{\circ}$ step size.

Acquired PXRD data were analysed (e.g. background subtraction, peak deconvolution, etc.) with the software PDXL 2 (Version 2.6.1.2) from Rigaku. Based on the elemental information from $\mu$-XRF measurements, phase identification analysis was carried out using the same software combined with the database PDF-4+ 2016 (ICDD).

\subsubsection{SEM - EDX}

A pre-powdered homogenous soil sample was fixed on the sample holder using carbon tape, introduced into the instrument and the instrument was evacuated. First the BSE image was taken to identify the heavy element holding particles. Then a rectangular area of the particle in the sample was measured with the EDX and the graph was evaluated with the help of the software. The image and the graph was taken by a Philips XL30 ESEM with a field emission electron soured and a silicon drift detector for EDX. The operational voltage was set to $25 \mathrm{kV}$. 


\subsection{Water}

\subsubsection{Water sample collection}

In almost four decades of war in Afghanistan nearly all infrastructures including city water supply and sewage systems were destroyed (Murcott, 2012). Drought, an increasing number of illegal housings without proper sewage systems, and heavy vehicles lacking technical inspection caused a huge pollution problem in Kabul and surrounding areas (Goudsouzian, 2011). About 20\% of the citizens of Kabul have access to the city water supply system, which is supplied by the Afghanistan Urban Water Supply and Sewerage Corporation (AUWSSC). In the rest of the city open or covered wells, unauthorized none standard water hand pumps, and streaming springs as all-purpose water source are used (Etemadi, 2016) . Therefore, it was important to initiate a qualitative as well as quantitative study on identifying the concentration of some heavy elements in water samples from Kabul. Although several studies were established by different organizations including United States Geology Survey (USGS) and German Federal Institute for Geosciences and Natural Resources (BGR) before, none of these studies and surveys covered heavy radioactive elements like thorium, uranium and radium sufficiently (Hayat \& Baba, 2017).

Like for the soil sampling, water sample collection was also performed in three different phases from March 2014 to October 2015. The sampling was carried out by the AAEHC in cooperation with AUWSSC. A total of 51 water samples were collected from different parts and sources of Kabul water. The samples were then shipped to the Institute for Radioecology and Radiation Protection IRS of the Leibniz Universität Hannover for further analysis. The study covers an area of about $600 \mathrm{~km}^{2}$ of Kabul and some of its districts. Attention was paid, collecting the samples from relatively diverse geology in and around Kabul. Samples comprise ground water as well as surface waters, being collected from city water supply taps, kitchen taps, confined and unconfined wells, streams, hand pumps, and bottled water. In the first phase eight water samples were collected from different city water supply stations and kitchen taps in March 2014; in the second phase, which started in October 2014, twenty four water samples were collected from open and closed wells, hand water pumps, and streaming springs at different sampling sites. In the third phase, which started in October 2015, twenty samples were collected from open and closed 
wells, hand water pumps, and an electrical water pump at different sampling sites. A map showing the sampling sites is given in Fig. 3.3; sampling sites are plotted in red.

Samples of volumes ranging from 50 to $100 \mathrm{ml}$ were bottled in sterilized bottles and sealed. The background radiation level measured by the RED Eye PRD was $\sim 50$ counts per second. Attention was paid to take representative samples from all areas of Kabul. To reduce possible contamination during sampling each tap connection of the city water supply system was heat sterilized with a gas torch before taking samples (Fig 3.4). GPS coordinates, names of sampling sites, background radiation, and measurement dates of the water samples are given in table 3.2.

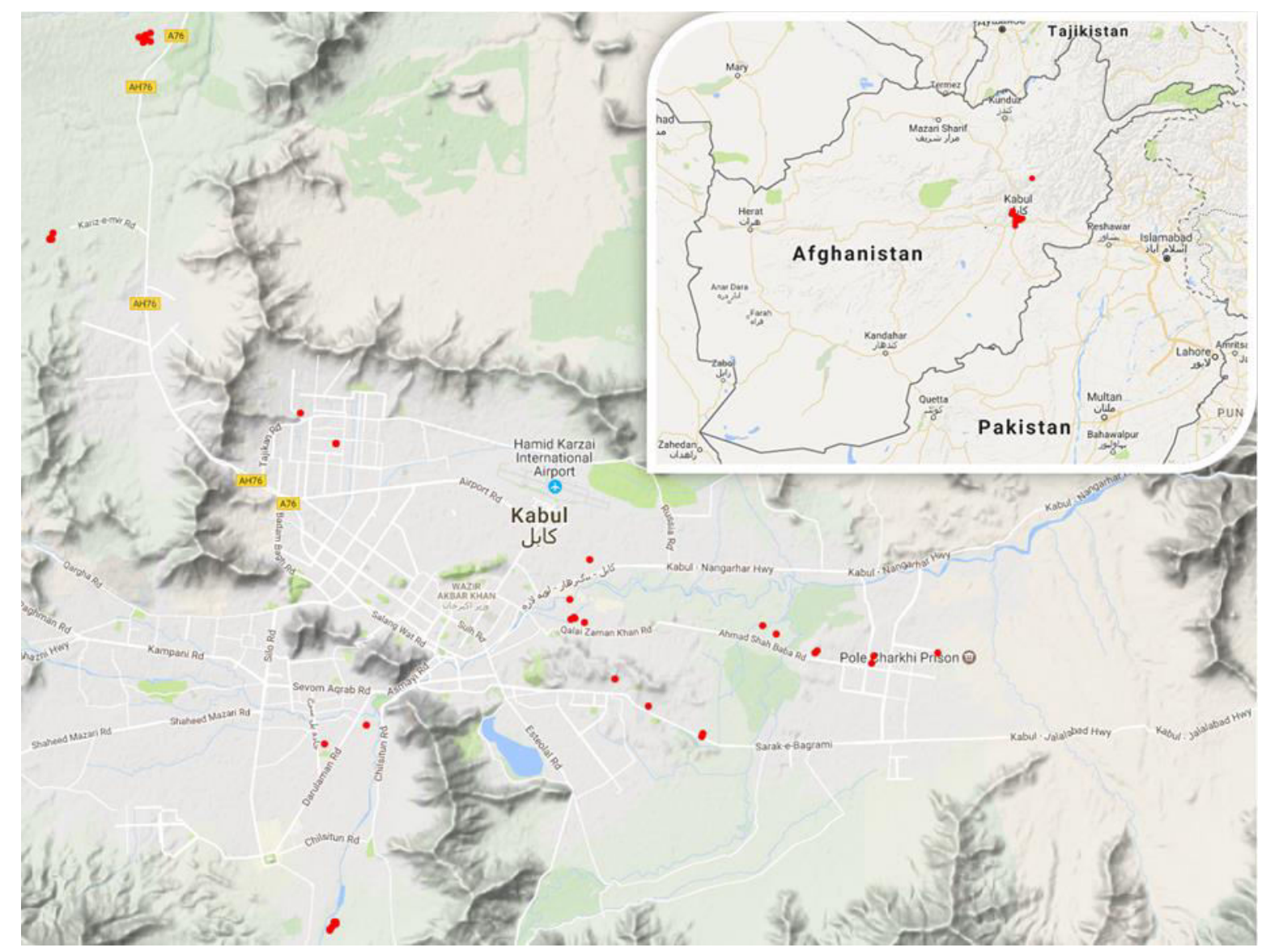

Fig.3.3 Sampling sites in Kabul and surrounding districts map (marked in red) 


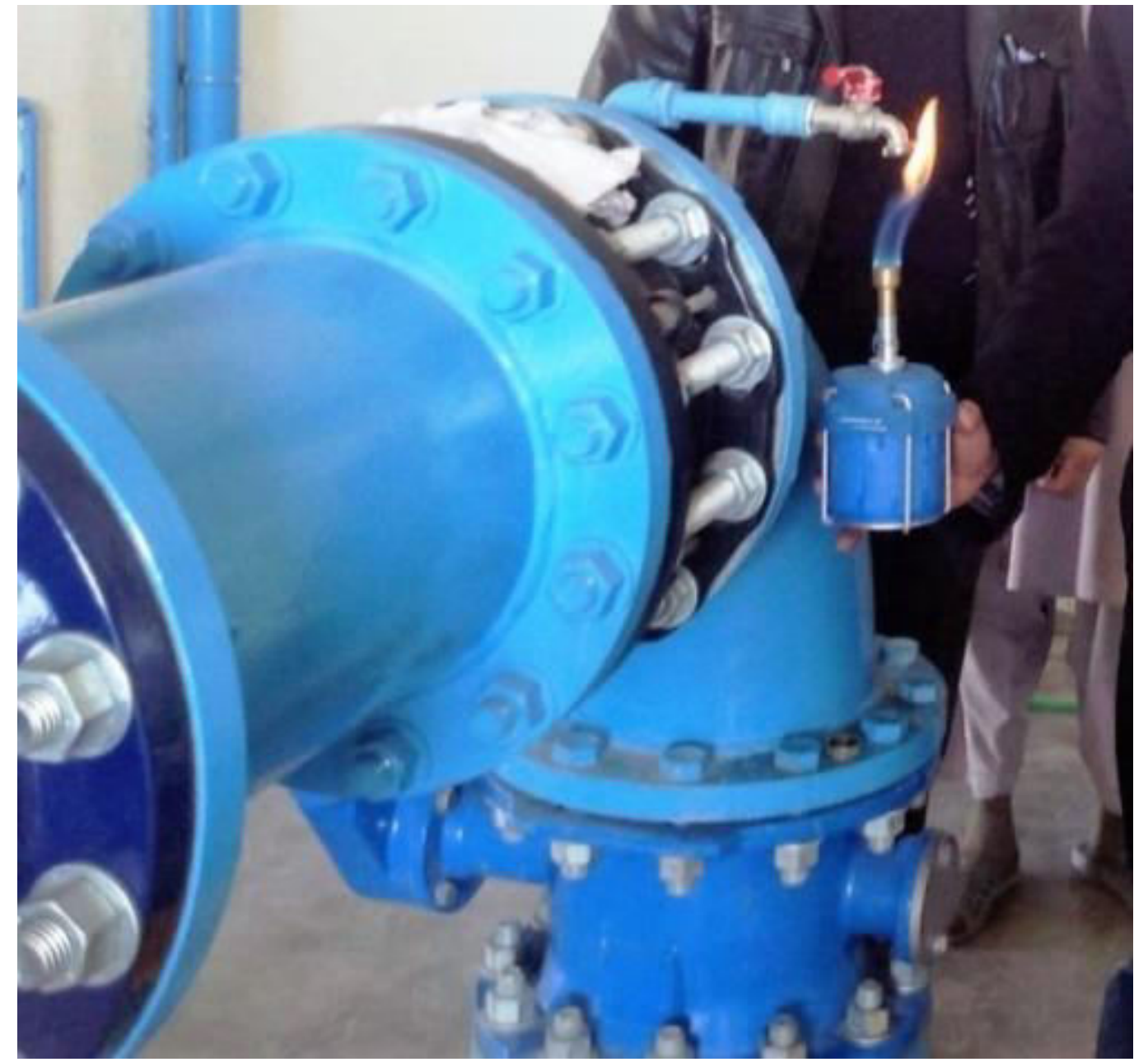

Fig.3.4: Heat sterilization of a water supply booster pump by a gas torch before sampling 
Table 3.2. Data and coordinates of samples and sampling sites.

\begin{tabular}{|c|c|c|c|c|c|}
\hline Phase & $\begin{array}{l}\text { Sample } \\
\#\end{array}$ & Sampling site & $\begin{array}{l}\text { GPS coordi- } \\
\text { nates }\end{array}$ & Source & Source condition \\
\hline \multirow{7}{*}{ 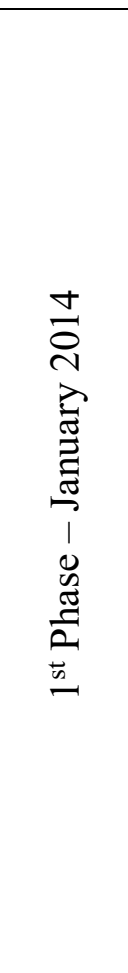 } & $1-2$ & $\begin{array}{l}\text { Supply Zone \#5 Sara } \\
\text { Mina, Kabul }\end{array}$ & $\begin{array}{l}\text { N } 34.5835400 \\
\text { E } 69.1460740\end{array}$ & Main well & $\begin{array}{l}\text { Well is fully covered; sample was taken directly from the steri- } \\
\text { lized open end of pipe (water tap) and stored in sterilized plas- } \\
\text { tic bottle. }\end{array}$ \\
\hline & $1-3$ & $\begin{array}{l}\text { Supply Zone \#5, } 500 \\
\text { Families, Kabul }\end{array}$ & $\begin{array}{l}\text { N } 34.584319^{0} \\
\text { E } 69.149953^{0}\end{array}$ & Well \#4 & $\begin{array}{c}\text { Well is fully covered; sample was taken directly from none } \\
\text { sterilized open end of pipe (water tap) and stored in sterilized } \\
\text { plastic bottle. }\end{array}$ \\
\hline & $1-4$ & $\begin{array}{l}\text { Supply Zone \#5 Prozha - } \\
\text { e- Jadeed, Kabul }\end{array}$ & $\begin{array}{l}\text { N } 34.599752^{0} \\
\text { E } 69.136561^{0}\end{array}$ & Well \#500 & $\begin{array}{l}\text { The well is fully covered and the sample was taken directly } \\
\text { from none sterilized open end of pipe (Water Tap) and stored in } \\
\text { sterilized plastic bottle. }\end{array}$ \\
\hline & $1-5$ & $\begin{array}{c}\text { Supply Zone \#5, Sarai - } \\
\text { e- Shamalee, Kabul }\end{array}$ & $\begin{array}{l}\text { N } 34.584485^{0} \\
\text { E } 69.129325^{0}\end{array}$ & Well \# 3000 & $\begin{array}{l}\text { The well is partially covered and the sample was taken directly } \\
\text { from none sterilized open end of pump (Water Tap) and stored } \\
\text { in sterilized plastic bottle. }\end{array}$ \\
\hline & $1-6$ & $\begin{array}{l}\text { Supply Zone \#1, Kart -e- } \\
\text { Naw, Kabul }\end{array}$ & $\begin{array}{l}\text { N } 34.512691^{0} \\
\text { E } 69.232279^{0}\end{array}$ & Well \# 1000 & $\begin{array}{l}\text { The well is partially covered and the sample was taken directly } \\
\text { from the well and stored in sterilized plastic bottle. }\end{array}$ \\
\hline & $1-7$ & $\begin{array}{c}\text { Supply Zone \#1 Bagrami } \\
\text { Dist, Kabul }\end{array}$ & $\begin{array}{l}\text { N } 34.497945^{0} \\
\text { E } 69.261243^{0}\end{array}$ & $\begin{array}{l}50 \text { m from booster } \\
\text { pump station }\end{array}$ & $\begin{array}{c}\text { The sample was taken directly from sterilized open end of a } \\
\text { residential area water pipe (Water Tap) and stored in sterilized } \\
\text { plastic bottle. }\end{array}$ \\
\hline & $1-8$ & $\begin{array}{c}\text { Supply Zone \#1 } \\
\text { Bagrami Dist, Kabul }\end{array}$ & $\begin{array}{l}\text { N } 34.497213^{0} \\
\text { E } 69.260795^{0}\end{array}$ & $\begin{array}{l}\text { Booster pump sta- } \\
\text { tion }\end{array}$ & $\begin{array}{l}\text { The well is sealed and the sample was taken directly from steri- } \\
\text { lized open end (Water Tap) of booster pipe and stored in steri- } \\
\text { lized plastic bottle. }\end{array}$ \\
\hline
\end{tabular}




\begin{tabular}{|c|c|c|c|c|c|}
\hline & $2-1$ & $\begin{array}{l}\text { Chahar asiaab Dist. Ka- } \\
\text { bul }\end{array}$ & $\begin{array}{l}\mathrm{N} 34.382938^{0} \\
\mathrm{E} 69.145745^{0}\end{array}$ & $\begin{array}{l}\text { Residential area } \\
\text { well }\end{array}$ & $\begin{array}{l}\text { The well is totally open and the sample was taken directly from } \\
\text { the well and stored in sterilized plastic bottle. }\end{array}$ \\
\hline \multirow{12}{*}{ 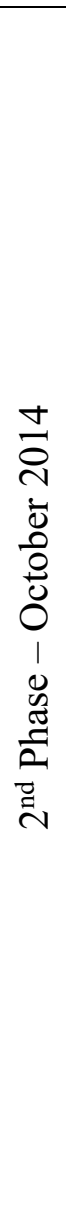 } & $2-2$ & $\begin{array}{l}\text { Qala Safeed - Char } \\
\text { Asyab, Kabul }\end{array}$ & $\begin{array}{l}\text { N } 34.379617^{0} \\
\text { E } 69.130564^{0}\end{array}$ & Hand pump & $\begin{array}{l}\text { Even the pump was fully covered but there was still possibility } \\
\text { for pollutants to get in }\end{array}$ \\
\hline & $2-3$ & $\begin{array}{l}\text { Qala Safeed - Char } \\
\text { Asyab, Kabul }\end{array}$ & $\begin{array}{l}\text { N } 34.379793^{0} \\
\text { E } 69.129744^{0}\end{array}$ & Hand pump & $\begin{array}{l}\text { Even pump was fully covered, but still portals of entry for pol- } \\
\text { lutants }\end{array}$ \\
\hline & $2-4$ & $\begin{array}{l}\text { Qala Ata Mohammad } \\
\text { Khan - Char Asyab, Ka- } \\
\text { bul }\end{array}$ & $\begin{array}{l}\text { N } 34.379034^{0} \\
\text { E } 69.144666^{0}\end{array}$ & Open well & $\begin{array}{l}\text { The well was totally open and pollutants can easily get in, } \\
\text { buckets were used to get water out of the well }\end{array}$ \\
\hline & $2-5$ & $\begin{array}{l}\text { Qala Luqman - Char } \\
\text { Asyab, Kabul }\end{array}$ & $\begin{array}{l}\mathrm{N} 34.368456^{0} \\
\mathrm{E} 69.140964^{0}\end{array}$ & Open well & $\begin{array}{c}\text { The well was totally open and pollutants can easily get in, } \\
\text { buckets were used to get water out of the well }\end{array}$ \\
\hline & $2-6$ & Alaudeen, Kabul & $\begin{array}{l}\text { N } 34.495190^{0} \\
\text { E } 69.137227^{0}\end{array}$ & City water supply & The water comes from fully covered city water supply tanks \\
\hline & $2-7$ & Lis-e- Habibiah Kabul & $\begin{array}{l}\text { N } 34.500378^{0} \\
\text { E } 69.150765^{0}\end{array}$ & Open well & $\begin{array}{l}\text { The well was totally open and pollutants can easily get in, } \\
\text { buckets were used to get water out of the well }\end{array}$ \\
\hline & $2-8$ & Qala-e-Logar, Kabul & $\begin{array}{l}\text { N } 34.445127^{0} \\
\text { E } 69.139006^{0}\end{array}$ & Open well & $\begin{array}{l}\text { The well was totally open and pollutants can easily get in, } \\
\text { buckets were used to get water out of the well }\end{array}$ \\
\hline & $2-9$ & Qala-e-Logar, Kabul & $\begin{array}{l}\text { N } 34.445810^{0} \\
\text { E } 69.139698^{0}\end{array}$ & Open well & $\begin{array}{l}\text { The well was totally open and pollutants can easily get in, } \\
\text { buckets were used to get water out of the well }\end{array}$ \\
\hline & $2-10$ & Qala-e-Logar, Kabul & $\begin{array}{l}\text { N } 34.444948^{0} \\
\text { E } 69.138926^{0}\end{array}$ & Hand pump & $\begin{array}{l}\text { Even the pump was fully covered but there was still possibility } \\
\text { for pollutants to get in }\end{array}$ \\
\hline & $2-11$ & Qala-e-Logar, Kabul & $\begin{array}{l}\text { N } 34.446606^{0} \\
\text { E } 69.141067^{0}\end{array}$ & Hand pump & $\begin{array}{l}\text { Even the pump was fully covered but there was still possibility } \\
\text { for pollutants to get in }\end{array}$ \\
\hline & $2-12$ & Qala-e-Logar, Kabul & $\begin{array}{l}\text { N } 34.447110^{0} \\
\text { E } 69.140199^{0}\end{array}$ & Open well & $\begin{array}{l}\text { The well was totally open and pollutants can easily get in, } \\
\text { buckets were used to get water out of the well }\end{array}$ \\
\hline & $2-13$ & Qala-e-Logar, Kabul & $\begin{array}{l}\text { N } 34.447097^{0} \\
\text { E } 69.140955^{0}\end{array}$ & Hand pump & $\begin{array}{l}\text { Even the pump was fully covered but there was still possibility } \\
\text { for pollutants to get in }\end{array}$ \\
\hline
\end{tabular}




\begin{tabular}{|c|c|c|c|c|c|}
\hline & $2-14$ & $\begin{array}{l}\text { Haji bakhshi village, } \\
\text { Shaker darah Kabul }\end{array}$ & $\begin{array}{l}\text { N } 34.685577^{0} \\
\text { E } 69.078843^{0}\end{array}$ & Open well & $\begin{array}{l}\text { The well was totally open and pollutants can easily get in, } \\
\text { buckets were used to get water out of the well }\end{array}$ \\
\hline & $2-15$ & $\begin{array}{l}\text { Haji bakhshi village, } \\
\text { Shaker darah Kabul }\end{array}$ & $\begin{array}{l}\text { N } 34.685892^{0} \\
\text { E } 69.077787^{0}\end{array}$ & Open well & $\begin{array}{c}\text { The well was totally open and pollutants can easily get in, } \\
\text { buckets were used to get water out of the well }\end{array}$ \\
\hline & $2-16$ & $\begin{array}{l}\text { Haji bakhshi village, } \\
\text { Shaker darah Kabul }\end{array}$ & $\begin{array}{l}\text { N } 34.684996^{0} \\
\text { E } 69.078092^{0}\end{array}$ & Open well & $\begin{array}{l}\text { The well was totally open and pollutants can easily get in, } \\
\text { buckets were used to get water out of the well }\end{array}$ \\
\hline & $2-17$ & $\begin{array}{l}\text { Haji bakhshi village, } \\
\text { Shaker darah Kabul }\end{array}$ & $\begin{array}{l}\text { N } 34.684776^{0} \\
\text { E } 69.080279^{0}\end{array}$ & Open well & $\begin{array}{l}\text { The well was totally open and pollutants can easily get in, } \\
\text { buckets were used to get water out of the well }\end{array}$ \\
\hline & $2-18$ & $\begin{array}{l}\text { Haji bakhshi village, } \\
\text { Shaker darah Kabul }\end{array}$ & $\begin{array}{l}\text { N } 34.684507^{0} \\
\text { E69.077795 }\end{array}$ & Open well & $\begin{array}{l}\text { The well was totally open and pollutants can easily get in, } \\
\text { buckets were used to get water out of the well }\end{array}$ \\
\hline & $2-19$ & $\begin{array}{l}\text { Haji bakhshi village, } \\
\text { Shaker darah Kabul }\end{array}$ & $\begin{array}{l}\text { N } 34.685950^{0} \\
\text { E } 69.076257^{0}\end{array}$ & Open well & $\begin{array}{c}\text { The well was totally open and pollutants can easily get in, } \\
\text { buckets were used to get water out of the well }\end{array}$ \\
\hline & $2-20$ & $\begin{array}{l}\text { Haji bakhshi village, } \\
\text { Shaker darah Kabul }\end{array}$ & $\begin{array}{l}\mathrm{N} 34.687201^{0} \\
\mathrm{E} 69.080225^{0}\end{array}$ & Open spring & $\begin{array}{c}\text { The spring is not covered by anything, human; animals and pets } \\
\text { used it as drinking water source }\end{array}$ \\
\hline & $2-21$ & $\begin{array}{l}\text { KINLEY mineral water } \\
\text { by Coca Cola Company }\end{array}$ & $\begin{array}{l}\text { N } 34.505454^{0} \\
\text { E } 69.243245^{0}\end{array}$ & Bottled & $\begin{array}{l}\text { The water was bottled and sealed by COCACOLA company of } \\
\text { Afghanistan in Kabul }\end{array}$ \\
\hline & $2-22$ & KAREZ mineral water & N/A & Bottled & $\begin{array}{c}\text { The water was bottled and sealed by KAREZ mineral water } \\
\text { company in Kabul }\end{array}$ \\
\hline & $2-23$ & $\begin{array}{l}\text { PANJSHER mineral wa- } \\
\text { ter }\end{array}$ & $\begin{array}{l}\text { N } 35.391625^{0} \\
\text { E } 69.581838^{0}\end{array}$ & Bottled & $\begin{array}{l}\text { The water was bottled and sealed by PANJSHER mineral water } \\
\text { company in Kabul }\end{array}$ \\
\hline & $3-1$ & Khair khana, Kabul & $\begin{array}{l}\mathrm{N} 34.576339^{0} \\
\text { E } 69.140793^{0}\end{array}$ & Kitchen tap & The water was supplied by fully covered water pump \\
\hline & $3-2$ & Sheenah $12^{\text {th }}$ dist & $\begin{array}{l}\text { N } 34.519825^{0} \\
\text { E } 69.297907^{0}\end{array}$ & Water Pump & $\begin{array}{c}\text { Even the well is fully covered but there was still possibility for } \\
\text { pollutants to get in }\end{array}$ \\
\hline 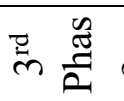 & $3-3$ & Alo khail $16^{\text {th }}$ dist & $\begin{array}{l}\text { N } 34.524920^{0} \\
\text { E } 69.284979^{0}\end{array}$ & Water Pump & $\begin{array}{c}\text { Even the well is fully covered but there was still possibility for } \\
\text { pollutants to get in }\end{array}$ \\
\hline
\end{tabular}




\begin{tabular}{|c|c|c|c|c|}
\hline $3-4$ & Sheena $12^{\text {th }}$ dist & $\begin{array}{l}\text { N } 34.520426^{0} \\
\text { E } 69.298334^{0}\end{array}$ & Water Pump & $\begin{array}{l}\text { Even the well is fully covered but there was still possibility for } \\
\text { pollutants to get in }\end{array}$ \\
\hline $3-5$ & Alo khail $16^{\text {th }}$ dist & $\begin{array}{l}\text { N } 34.527148^{0} \\
\text { E } 69.280599^{0}\end{array}$ & Hand pump & $\begin{array}{c}\text { Even the well is fully covered but there was still possibility for } \\
\text { pollutants to get in }\end{array}$ \\
\hline $3-6$ & Deh Khudaidad $16^{\text {th }}$ dist & $\begin{array}{l}\text { N } 34.534295^{0} \\
\text { E } 69.217324^{0}\end{array}$ & Hand pump & $\begin{array}{l}\text { The pump and the well is partly covered and there is possibility } \\
\text { for pollutants to get in }\end{array}$ \\
\hline $3-7$ & Qala Charkhi $8^{\text {th }}$ dist & $\begin{array}{l}\text { N } 34.519891^{0} \\
\text { E } 69.337811^{0}\end{array}$ & Hand pump & $\begin{array}{l}\text { The pump and the well is partly covered and there is possibility } \\
\text { for pollutants to get in }\end{array}$ \\
\hline $3-8$ & Chah Habib $8^{\text {th }}$ dist & $\begin{array}{l}\text { N } 34.519079^{0} \\
\text { E } 69.316965^{0}\end{array}$ & Hand pump & $\begin{array}{c}\text { The pump and the well is partly covered and there is possibility } \\
\text { for pollutants to get in }\end{array}$ \\
\hline $3-9$ & Chenar Ha $8^{\text {th }}$ dist & $\begin{array}{l}\text { N } 34.516998^{0} \\
\text { E } 69.316242^{0}\end{array}$ & Hand pump & $\begin{array}{c}\text { The pump and the well is partly covered and there is possibility } \\
\text { for pollutants to get in }\end{array}$ \\
\hline $3-10$ & Naw abad $16^{\text {th }}$ dist & $\begin{array}{l}\text { N } 34.545051^{0} \\
\text { E } 69.223995^{0}\end{array}$ & Hand pump & $\begin{array}{l}\text { The pump and the well is partly covered and there is possibility } \\
\text { for pollutants to get in }\end{array}$ \\
\hline $3-11$ & Qala Zaman $16^{\text {th }}$ dist & $\begin{array}{l}\text { N } 34.527982^{0} \\
\text { E } 69.222232^{0}\end{array}$ & Water Pump & $\begin{array}{l}\text { Even the well is fully covered but there was still possibility for } \\
\text { pollutants to get in }\end{array}$ \\
\hline $3-12$ & Masjeed Kareez & $\begin{array}{l}\text { N } 34.631732^{0} \\
\text { E } 69.047479^{0}\end{array}$ & Open Spring & $\begin{array}{c}\text { The spring is totally open and pollutants can easily get in, } \\
\text { buckets are used to get water }\end{array}$ \\
\hline $3-13$ & Milad House Kareez & $\begin{array}{l}\text { N } 34.631399^{0} \\
\text { E } 69.047044^{0}\end{array}$ & Open Spring & $\begin{array}{c}\text { The spring is totally open and pollutants can easily get in, } \\
\text { buckets are used to get water }\end{array}$ \\
\hline $3-14$ & Wahid kor $16^{\text {th }}$ dist & $\begin{array}{l}\text { N } 34.529007^{0} \\
\text { E } 69.217668^{0}\end{array}$ & Open well & $\begin{array}{l}\text { The well is totally open and pollutants can easily get in, buck- } \\
\text { ets are used to get water }\end{array}$ \\
\hline $3-15$ & Kaka kor $16^{\text {th }}$ dist & $\begin{array}{l}\text { N } 34.529060^{0} \\
\text { E } 69.219121^{0}\end{array}$ & Open well & $\begin{array}{l}\text { The well is totally open and pollutants can easily get in, buck- } \\
\text { ets are used to get water }\end{array}$ \\
\hline $3-16$ & Wahid Hamsiah $16^{\text {th }}$ dist & $\begin{array}{l}\text { N } 34.529537^{0} \\
\text { E } 69.218713^{0}\end{array}$ & Open well & $\begin{array}{l}\text { The well is totally open and pollutants can easily get in, buck- } \\
\text { ets are used to get water }\end{array}$ \\
\hline
\end{tabular}




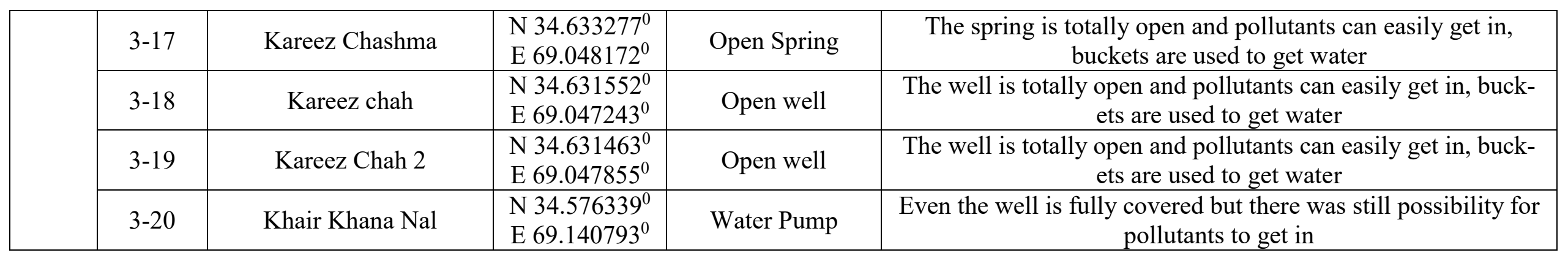




\subsubsection{Sample preparation and measurement}

Prior to the measurements samples were filtered (Rotilabo-syringe filters, CA, unsterile pore size: 0, $45 \mu \mathrm{m}$ manufactured by Carl Roth $\mathrm{GmbH} \&$ Co. KG). Samples that showed high concentrations of radionuclides in the first round of measurements were diluted with Milli-Q water to different factors. Afterwards, samples were rebottled in 50ml plastic vials and a multi standard calibration method was performed before measurement. None of the samples underwent chemical modification.

Following AUWSSC's internal procedure and suggestion, the samples collected in the first phase were investigated for zinc, arsenic, nickel, lead, manganese, copper, chromium, barium, aluminum, sodium, magnesium, calcium, and uranium, while in the second and third phase only heavy radionuclides, namely uranium, thorium, and radium were investigated.

Several methods including gamma and alpha spectroscopy, ICP-OES, and ICP-MS were used to verify the measurement results.

Gamma spectroscopy was done using HPGe (high purity germanium) detectors, produced by Canberra with a relative efficiency of about $30 \%$ of the standard 3 in. x 3 in. $\mathrm{NaI}(\mathrm{Tl})$ Scintillation detector and energy resolution (FWHM) of $1.8 \mathrm{keV}$ for the $1.33 \mathrm{MeV}$ line. The same setup and procedure of measurement was used as for the rock and soil samples. The empty bottles were also measured with the identical setup and time interval for acquisition of the background count rate, which was then subtracted from the gross count rate of the samples.

The water samples of the first sampling phase were measured by gamma spectroscopy without pre-treatment. No considerable activity was observed. In the next step, ICP-OES and ICP-MS systems were utilized for element identification. Samples were rebottled in $50 \mathrm{ml}$ plastic vials; a multi standard calibration method with different dilution factors for better accuracy was performed. $\mathrm{Zn}, \mathrm{As}, \mathrm{Ni}, \mathrm{Pb}, \mathrm{Mn}, \mathrm{Cu}, \mathrm{Cr}, \mathrm{Ba}, \mathrm{Al}$, and $\mathrm{U}$ were measured with the ICP-MS system, whereas $\mathrm{Na}, \mathrm{Ca}, \mathrm{Fe}, \mathrm{K}$, and $\mathrm{Pb}$ were measured by ICP-OES.

It is equipped with Qtegra software used for data processing. For the evaluation in ppb or ppm, the calibration factor for each isotope was calculated using an external standard. 
Under optimal conditions the detection limits of ICP-MS for uranium, thorium, lead, and radium are given as 2, 1, 5, and 1 ppt, respectively (Inorganic Ventures, 2017).

In the second phase, 23 water samples from different areas of Kabul were investigated for $\mathrm{U}, \mathrm{Ra}$, Th and $\mathrm{Pb}$. Measurements of all samples were carried out by ICP-MS. Standards were prepared with nitric acid with a concentration of $2 \%$. If necessary, samples were diluted with Milli-Q water to match the calibration range.

The samples of the third phase were measured with focus on heavy radionuclides namely $\mathrm{U}, \mathrm{Ra}, \mathrm{Th}$, and $\mathrm{Pb}$ using the same ICP-MS device. As in phase two, all samples were filtered and diluted if necessary. Samples number 1, 2, 3, 4, 5, 6, 19, 20, 21, 22 and 23 were additionally measured by LSC in order to verify the absence of radium in the samples.

\subsection{Radon}

\subsubsection{Radon sampling}

Uranium is present in varying amounts in virtually all rocks and soils. It is the main source of indoor and outdoor radon exposure. The concentration remains low if radon emanates to an open area, while it increases in enclosed spaces (Samet, 1992). As a consequence of the long lasting and still ongoing war followed by migration of the rural population to the big cities, illegal houses were built, often without appropriate ventilation and sewage system (Jeff Crisp, 2011).Also caves are used for housing, as either permanent residence or short-term shelters. In order to assess the risk of radon in caves and other confined spaces, the concentration of radon gas needs to be determined. To this date, no study has been performed to determine the radon concentration levels in residential buildings in Afghanistan. The present work used the newly developed real-time measurement device to assess the dose in some caves as well as houses in Panjsher and Kabul, Afghanistan. The measurements were established in two separate phases with the first phase starting in October 2015. Four houses and four caves were chosen as measurements sites. To assess an annual dose, the second measuring phase was performed between September 2015 and September 2016. In this phase, four living rooms and four basements in four different areas of Kabul were chosen as measurement sites. In order to test seasonal 
changes in radon concentrations monitoring was performed for one full year. The measurement time for each device differed due to technical difficulties in the measurement procedure. No preparations for the sampling sites were needed, except resetting the device manually with the help of a laptop, software and some connecting cables. Ventilation status of the sites were also recorded. Fig.3.5 shows the map of Kabul and Panjshir province with the sampling sites marked in red. GPS coordinates, names of the sampling sites, device IDs, and measurement dates are given in table 3.3. The reason for choosing these locations for sampling sites was their geographical position and the diversity of constructional materials used as well as accessibility and availability

a
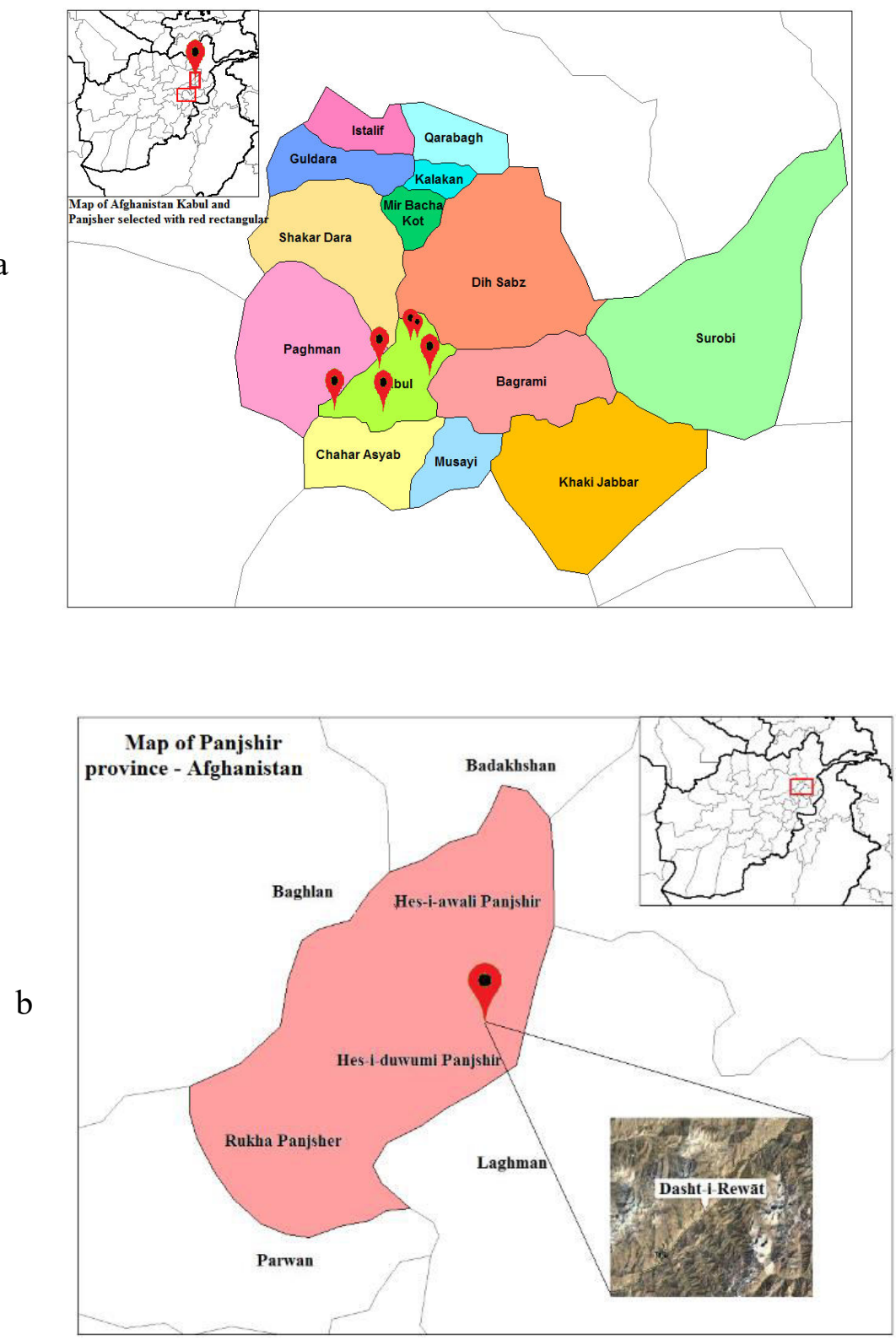

Fig.3.5: Map of Kabul (a) and Panjshir province (b); sampling sites marked in red. 
Tab. 3.3. Data and coordinates of samples and sampling sites.

\begin{tabular}{|c|c|c|c|c|c|}
\hline Date & $\begin{array}{l}\text { Device } \\
\text { ID }\end{array}$ & $\begin{array}{l}\text { GPS coordi- } \\
\text { nates }\end{array}$ & Sampling site & $\begin{array}{l}\text { Type of the } \\
\text { space }\end{array}$ & Construction type and age \\
\hline \multirow{8}{*}{ 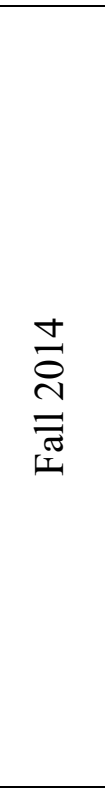 } & V 309 & $\begin{array}{l}\text { N } 34.584421^{0} \\
\text { E } 69.155582^{0}\end{array}$ & $\begin{array}{c}\text { Sher Pacha base- } \\
\text { ment }\end{array}$ & House & House constructed in 2014; concrete, bricks \\
\hline & V 317 & $\begin{array}{l}\text { N } 34.584435^{0} \\
\text { E } 69.155361^{0}\end{array}$ & Agha basement & House & Constructed 1970; Adobe bricks, covered with cement rendering \\
\hline & V 326 & $\begin{array}{l}\text { N } 34.589251^{0} \\
\text { E } 69.156174^{0}\end{array}$ & Karim 1 basement & House & Constructed in 2012; concrete, bricks \\
\hline & V 331 & $\begin{array}{l}\text { N } 34.589265^{0} \\
\text { E } 69.156030^{\circ}\end{array}$ & Karim 2 basement & House & “ \\
\hline & V 309 & $\begin{array}{l}\text { N } 35.284841^{0} \\
\text { E } 69.495710^{0}\end{array}$ & Haji Dost & Cave & Cave excavated in 2013; solid rocks \\
\hline & V 317 & $\begin{array}{l}\text { N } 35.284063^{0} \\
\text { E } 69.495731^{0}\end{array}$ & Gen Azumdin & Cave & “ \\
\hline & V 326 & $\begin{array}{l}\text { N } 35.284252^{0} \\
\text { E } 69.495701^{0}\end{array}$ & Qurban & Cave & “ \\
\hline & V 331 & $\begin{array}{l}\text { N } 35.284294^{0} \\
\text { E } 69.495705^{0}\end{array}$ & Maazudin & Cave & “ \\
\hline \multirow{3}{*}{ 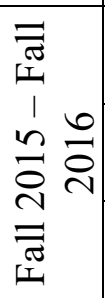 } & V 309 & $\begin{array}{l}\text { N } 34.504987^{0} \\
\text { E } 69.098102^{0}\end{array}$ & Mirza Room & House & Constructed after 2010; concrete, bricks, ceramic tiles \\
\hline & V 311 & $\begin{array}{l}\text { N } 34.541523^{0} \\
\text { E } 69.047857^{0} \\
\end{array}$ & $\begin{array}{c}\text { Abobaker Base- } \\
\text { ment }\end{array}$ & House & Constructed in 1980s; adobe, cement rendering \\
\hline & V 315 & $\begin{array}{l}\text { N } 34.522385^{0} \\
\text { E } 69.119731^{0}\end{array}$ & AAEHC Basement & House & Constructed in $1950 \mathrm{~s}$; concrete \\
\hline
\end{tabular}




\begin{tabular}{|c|c|c|c|c|}
\hline V 317 & $\begin{array}{l}\text { N } 34.510362^{0} \\
\text { E } 69.242040^{0}\end{array}$ & Samay Basement & House & $\begin{array}{c}\text { Constructed in } 2008 \text { on temporary basis; puddle clay, rocks, cement } \\
\text { rendering }\end{array}$ \\
\hline V 321 & $\begin{array}{l}\text { N } 34.541523^{0} \\
\text { E } 69.047857^{0}\end{array}$ & Abobaker Room & House & (see above) \\
\hline V 326 & $\begin{array}{l}\text { N } 34.504987^{0} \\
\text { E } 69.098102^{0}\end{array}$ & Mirza Basement & House & (see above) \\
\hline V 330 & $\begin{array}{l}\mathrm{N} 34.522385^{0} \\
\mathrm{E} 69.119731^{0}\end{array}$ & AAEHC Hall & House & (see above) \\
\hline V 331 & $\begin{array}{l}\text { N } 34.510362^{0} \\
\text { E } 69.242040^{0}\end{array}$ & Samay Room & House & (see above) \\
\hline
\end{tabular}




\subsubsection{Radon measurements}

Before measuring, the device needs to be reset with the help of software and a connector. After the reset, the devices were placed on the floor close to a wall for practical reasons, to avoid interference by persons and possible physical damage to the device (assuming constant indoor distribution of the noble gas radon, an assumption which is usually made for inhabited rooms). Radon concentrations were recorded every 10 minutes. The measurement duration differed depending on location. As the devices have no manual on/off switches, they keep on recording unless the battery is removed. Thus, following the measurement, a laptop was taken to the sampling site for on-site transfer of data from the device. Raw data were then converted into an excel file for evaluation.

\subsubsection{Device Calibration}

The devices employed in this work have been calibrated following the recent ISO standard for radon measurements (ISO, 2012). As radon source, pitchblende was employed. A gamma-spectrometric analysis of a $538 \mathrm{mg}$ rock resulted in a specific ${ }^{226} \mathrm{Ra}$ activity of $23.0 \pm 0.4 \mathrm{~Bq} / \mathrm{g}$. As secondary calibration standard, a Saphymo AlphaGuard was used. The calibration is traceable since it was calibrated at the PTB (German metrology agency). During the calibration process, all the devices (exposimeter and AlphaGuard) as well as the radon source were placed in a hermetically sealable steel vessel. Radon concentration would be stable after about 23 days, if a completely tight vessel with a semipermeable source is used. Note that in a less airtight calibration chamber, equilibrium between emanation of the source and loss through leakage will be reached in a shorter time (Nazaroff \& Nero, 1988). After equilibrium has been reached, the setup was left undisturbed for several days. The calibration factor and its standard deviation were then, for each device, derived from the hourly count rates and the measured radon concentration. Theoretically, the calibration factors of the devices depend on casing size and environmental conditions such as temperature and air pressure (altitude). For the casing size used here, Monte Carlo simulations (results not shown) showed that the calibration factor differed by less than a few percent, for the altitude and temperature where the calibration was performed (Munich, Germany; around $500 \mathrm{~m}$ asl; $20^{\circ} \mathrm{C}$ ), when compared to altitude and temperature where the measurements were performed (Kabul, around $1800 \mathrm{~m}$ asl; 
Panjsher province, around $2300 \mathrm{~m}$ asl; down to $-2.9^{\circ} \mathrm{C}$ ) (Irlinger, 2014). Thus, no corrections were applied.

\subsubsection{Measurement conditions}

In the first phase of measurements launched in October 2014, none of the sites had electrical ventilation, but the house basements had at least one entrance and one glass window, while the caves only had one entrance. The second measurement phase was launched in fall (10 to 17 October 2015). Follow up measurements were performed in winter (20 to 27 January 2016), spring (20 and 27 May 2016), and summer (1 to 7 September 2016). During the measurement in spring, the device V 317 failed, and was substituted by V 331 for Samay home and basement for the spring and summer measurements. In none of the buildings appropriate electrical ventilation systems were installed in the above-ground rooms, but all of them had an entrance, some had one or two windows as well. The devices were placed in the same GPS coordinates on different floor levels.

For the sampling locations in Kabul an annual temperature graph of Kabul city is shown in Fig. 3.6. The city is influenced by the local steppe climate; the average annual temperature and precipitation are $11.4{ }^{\circ} \mathrm{C}$ and $362 \mathrm{~mm}$, respectively, with the highest temperature in July $\left(23.2^{\circ} \mathrm{C}\right)$ and the lowest in January $\left(-2.9^{\circ} \mathrm{C}\right)$. The driest month June has an average of $1 \mathrm{~mm}$ rainfall, while March as the wettest month has an average of $88 \mathrm{~mm}$ rainfall.

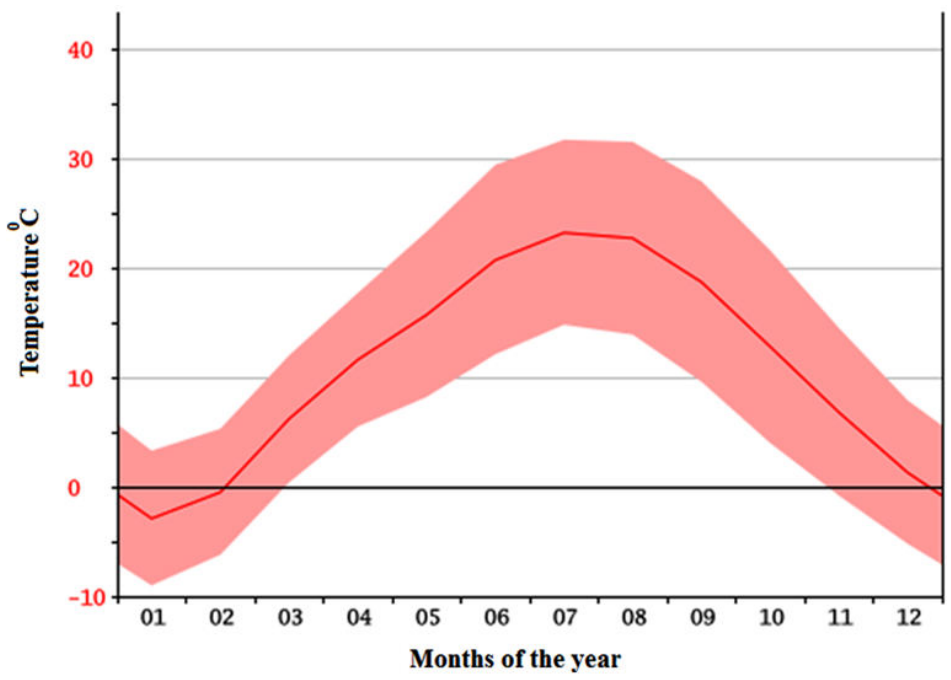

Fig.3.6: Average annual temperatures in Kabul city (Climate data) 


\section{Chapter}

\section{Results and discussions}

\subsection{Rock and soil}

\subsubsection{Gamma spectroscopy}

Considerable amounts of ${ }^{238} \mathrm{U},{ }^{235} \mathrm{U}$ and ${ }^{232} \mathrm{Th}$ were detected in samples from the first and second phase, whereas in the third phase only the ${ }^{238} \mathrm{U}$ series daughter ${ }^{226} \mathrm{Ra}$, was detected. Signals from all of the isotopes of the ${ }^{238} \mathrm{U}$ and ${ }^{235} \mathrm{U}$ series were lower than the detection limit. A combined average activity concentration of all three phases is shown in Fig.4.1, where isotopes are plotted on the $\mathrm{x}$-axis and the $\mathrm{y}$-axis shows the activity in a logarithmic scale. The maximum and minimum activity concentrations of all three phases are shown in Table.4.1. 


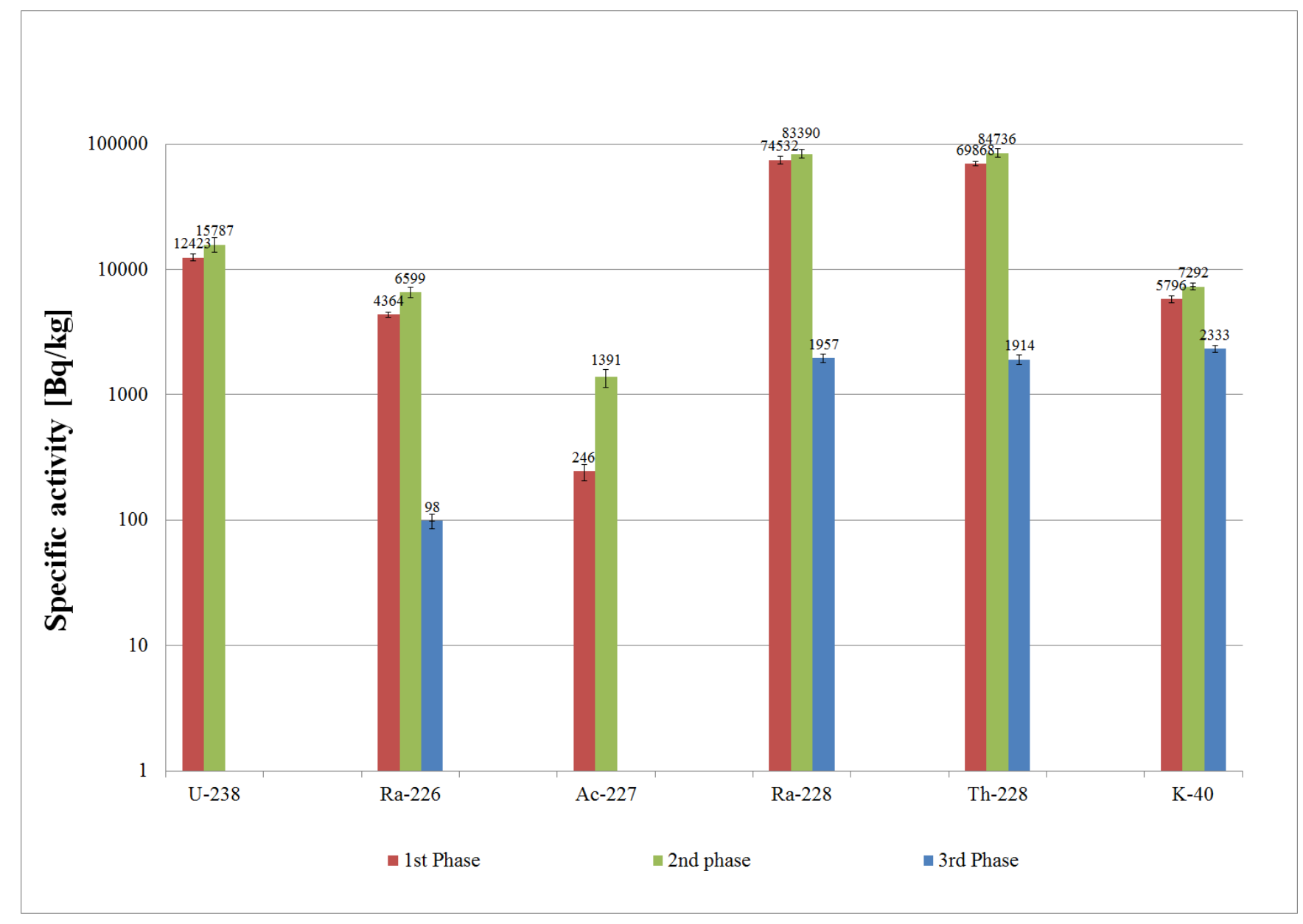

Fig. 4.1: Activity concentration of different isotopes of the uranium, actinium and thorium series. 
Table 4.1: Maximum and minimum activity concentrations of the samples from the three sampling phases

\begin{tabular}{|l|l|l|l|l|l|l|l|}
\hline Phase & Activity $[\mathbf{B q} / \mathbf{k g}]$ & ${ }^{\mathbf{2 3 8}} \mathbf{U}$ & ${ }^{\mathbf{2 2 6}} \mathbf{R a}$ & ${ }^{\mathbf{2 2 7}} \mathbf{A c}$ & ${ }^{\mathbf{2 2 8}} \mathbf{R a}$ & ${ }^{\mathbf{2 2 8}} \mathbf{T h}$ & ${ }^{\mathbf{4}} \mathbf{K}$ \\
\hline \multirow{2}{*}{ 1st } & Max & $28660 \pm 1670$ & $10700 \pm 400$ & $540 \pm 100$ & $203000 \pm 8000$ & $212000 \pm 6200$ & $15230 \pm 845$ \\
\cline { 2 - 8 } & Min & $1200 \pm 112$ & $1300 \pm 175$ & $68 \pm 7$ & $1900 \pm 100$ & $195 \pm 10$ & $273 \pm 50$ \\
\hline \multirow{2}{*}{ 2nd } & Max & $33500 \pm 6600$ & $38300 \pm 7100$ & $3900 \pm 600$ & $347000 \pm 28000$ & $383000 \pm 30500$ & $24700 \pm 1300$ \\
\cline { 2 - 8 } & Min & $167 \pm 57$ & $55 \pm 5$ & $84 \pm 8$ & $90 \pm 10$ & $75 \pm 10$ & $615 \pm 68$ \\
\hline \multirow{2}{*}{ 3rd } & Max & LDL & $270 \pm 11$ & LDL & $6000 \pm 680$ & $5900 \pm 670$ & $4950 \pm 300$ \\
\cline { 2 - 8 } & Min & LDL & $20 \pm 1$ & LDL & $177 \pm 17$ & $147 \pm 14$ & $400 \pm 40$ \\
\hline
\end{tabular}

As can be seen from figure.4.1 and table.4.1 the activity concentrations of ${ }^{238} \mathrm{U}$ and its progeny ${ }^{226} \mathrm{Ra}$, of the ${ }^{235} \mathrm{U}$ progeny ${ }^{227} \mathrm{Ac}$, and of ${ }^{232} \mathrm{Th}$ progenies ${ }^{228} \mathrm{Ra}$ and ${ }^{228} \mathrm{Th}$ in our samples were higher than the concentrations reported for rocks and soils from other places (Bundesamt für Strahlenschutz, 2014). 
The activity ratio of ${ }^{238} \mathrm{U} /{ }^{235} \mathrm{U}$ ranges between 1 and 40 , which is different from the value of 21.7 discussed in literature for undisturbed natural uranium (Minteer et al., 2007).

As far as the geology of the sampling area is concerned, veins of magmatic granite are reported for the Kabul geological block (Wolfart, 1980). A comparative study reports significant amounts of granite gneisses containing radioactive elements in the mountains surrounding Kabul (Andritzky, 1971). Additionally, Afghanistan is reported as promising exploration area for uranium due to being member of a series of granitic rock orogenic belts (International Atomic Energy Agency, 1989). Furthermore, thorium bearing monazite minerals are reported for Kabul surrounding hills (Faryad et al., 2016). Similarly, an unusually high natural radioactivity originating from enhanced concentrations of thorium in monazite minerals are reported for some beach sands in India, Iran, Brazil, and China (Eisenbud \& Gesell, 1997).

\subsubsection{Alpha spectroscopy}

All investigated samples show a clear excess of thorium over uranium with the thorium activity being 1.7 to 20.5 times higher than the uranium activities. On average, the thorium activity is 8.7 times that of the uranium activity. Alpha spectrometry results do not indicate the presence of artificial or abnormal uranium isotope composition, and both isotope ratios of ${ }^{234} \mathrm{U} /{ }^{238} \mathrm{U}$ and ${ }^{235} \mathrm{U} /{ }^{238} \mathrm{U}$, respectively, are consistent with the natural isotope composition of uranium.

The majority of the samples show compliant activities for ${ }^{238} \mathrm{U}$ and ${ }^{230} \mathrm{Th}$, confirming the expected secular equilibrium. Those samples showing considerable deviations from the equilibrium in both directions might probably be influenced by surficial weathering of the rocks (Bottrell, 1993; Siddeeg \& Livens, 2013).

The specific activity concentration of the natural uranium and thorium series as well as the ${ }^{234} \mathrm{U} /{ }^{238} \mathrm{U}$ ratio in measured samples are illustrated in Fig.4.2a and 4.2b respectively. 


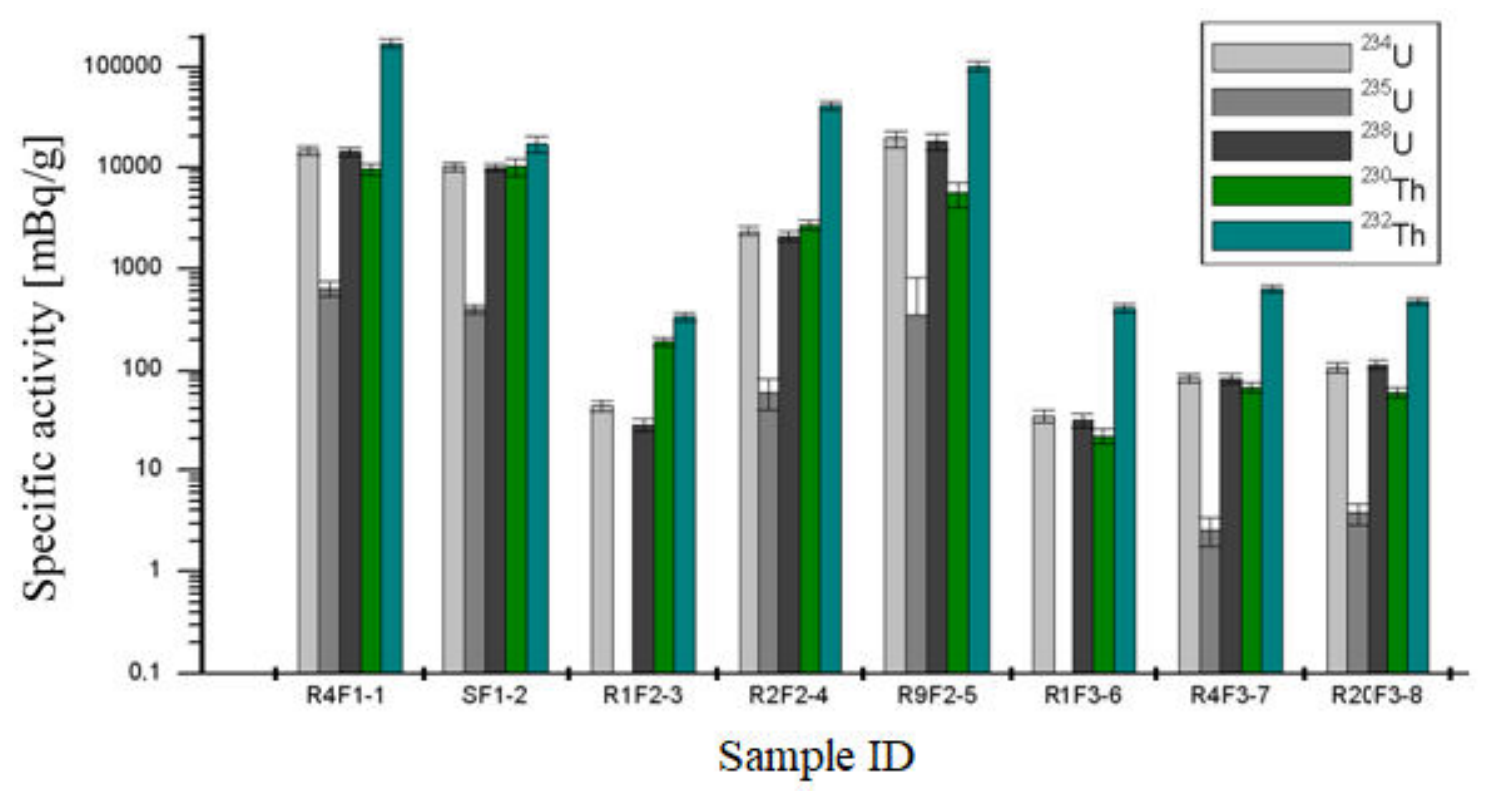

Fig.4.2a

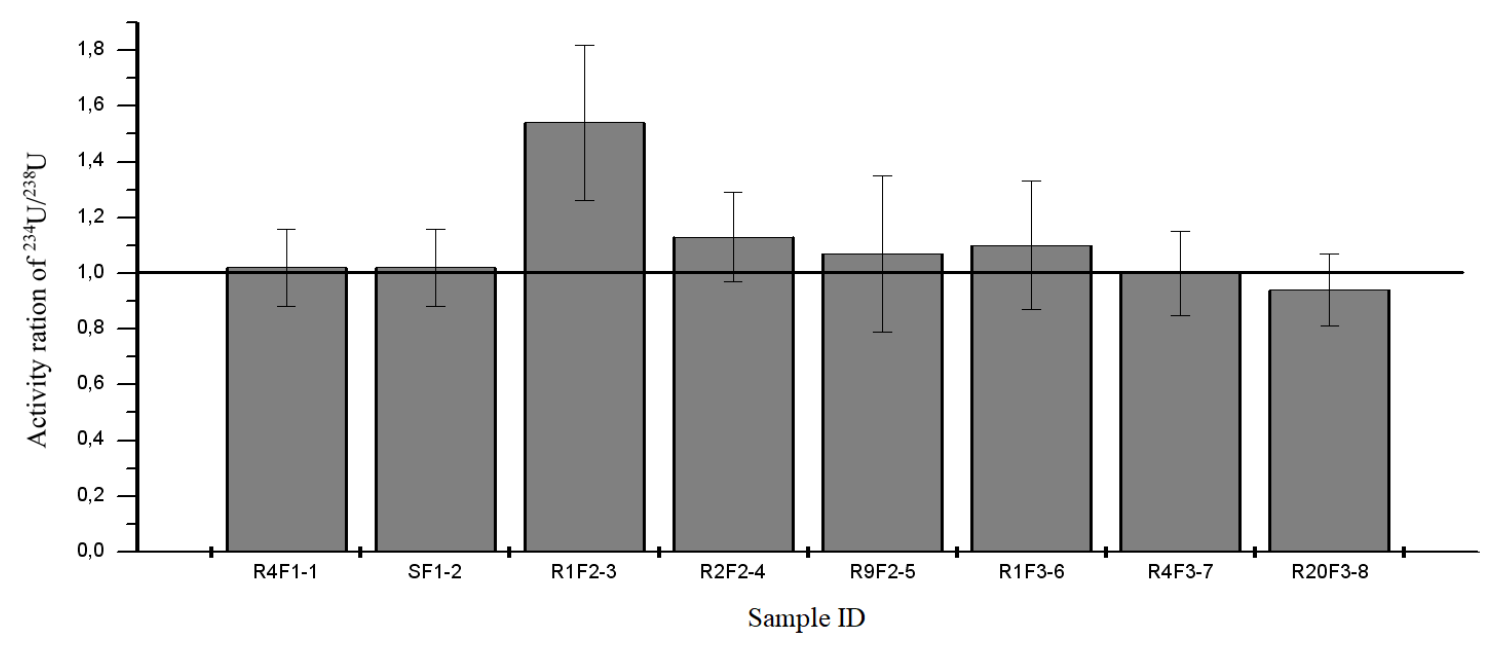

Fig.4.ba

\subsubsection{TOF-SIMS}

First analyses by TOF-SIMS showed a high amount of thorium and uranium containing particles distributed on an area of $500 \times 500 \mu \mathrm{m}$. One of these particles was analysed with a special mode for high quality secondary ion images. These images are presented in figures $4.3 \mathrm{a}$ and $4.3 \mathrm{~b}$, showing that this particle contains $\mathrm{U}, \mathrm{Th}, \mathrm{Y}$, and $\mathrm{O}$. The matrix surrounding the particle contains various elements such as $\mathrm{Si}, \mathrm{Na}, \mathrm{Ca}, \mathrm{K}, \mathrm{O}, \mathrm{Al}$, and Fe. It could not be shown clearly, whether the sample contains lanthanides as well as P. 

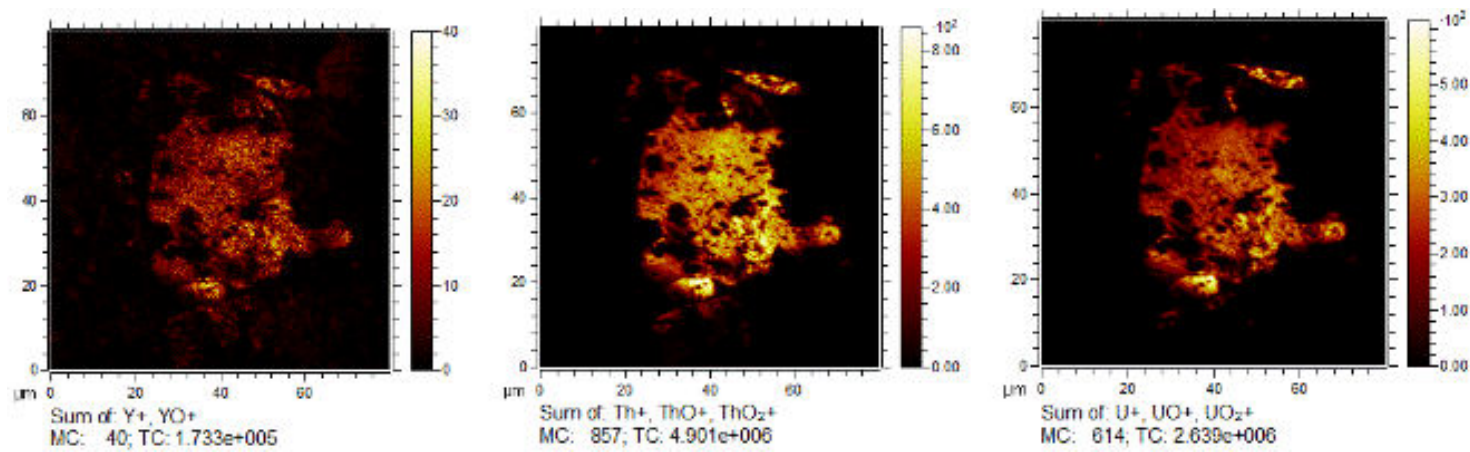

Fig.4.3a

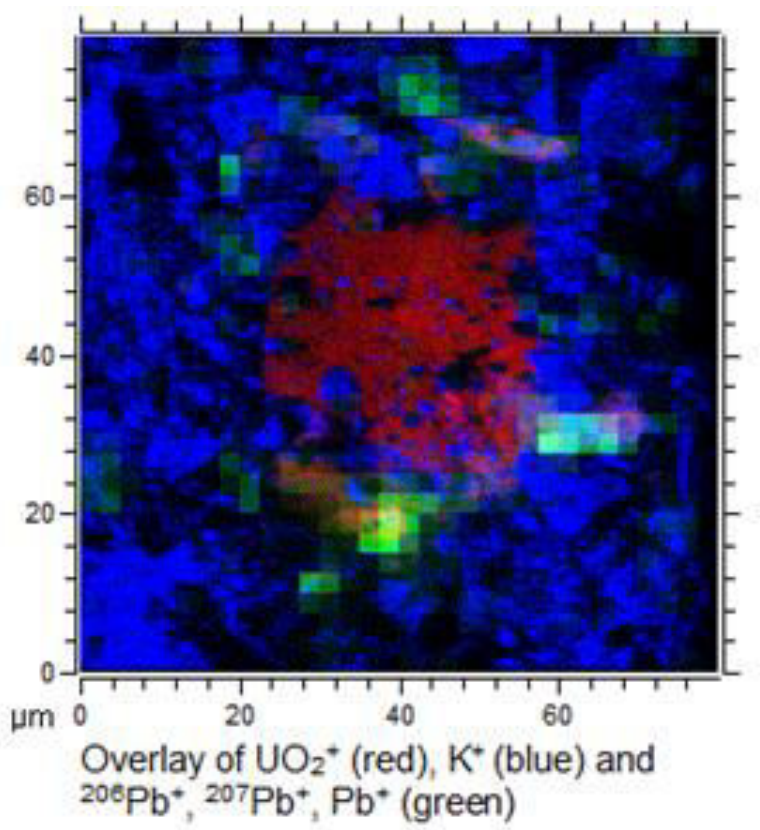

Fig. $4.3 b$

Fig.4.3a and 4.3b: TOF-SIMS images: 80 x $80 \mu \mathrm{m}, 512$ x 512 pixel, 275 scans, $6994 \mathrm{~s}$, $\mathrm{Bi}^{3+}$.

The ${ }^{235} \mathrm{U} /{ }^{238} \mathrm{U}$ isotopic ratio of this particle was determined by a SIMS measurement with a high mass resolution. The peak areas $n_{b}$ of ${ }^{235} U$ and ${ }^{238} U$ were determined, as well as the corresponding background areas $n_{0}$, resulting in the net peak area $n_{n}=n_{b}-n_{0}$. The uncertainties are given by $u\left(n_{b}\right)=\sqrt{n_{b}}, u\left(n_{0}\right)=\sqrt{n_{0}}$ and $u\left(n_{n}\right)=\sqrt{n_{b}+n_{0}}$ (BIPM, 2008). Data are given in table 1. This results in the isotopic ratio

$$
\frac{\mathrm{n}_{\mathrm{n}, 235}}{\mathrm{n}_{\mathrm{n}, 238}}=0.00755
$$


with an uncertainty of

$$
\mathrm{u}\left(\frac{\mathrm{n}_{\mathrm{n}, 235}}{\mathrm{n}_{\mathrm{n}, 238}}\right)=\frac{\mathrm{n}_{\mathrm{n}, 235}}{\mathrm{n}_{\mathrm{n}, 238}} \sqrt{\frac{\mathrm{u}^{2}\left(\mathrm{n}_{\mathrm{n}, 235}\right)}{\mathrm{n}_{\mathrm{n}, 235}^{2}}+\frac{\mathrm{u}^{2}\left(\mathrm{n}_{\mathrm{n}, 238}\right)}{\mathrm{n}_{\mathrm{n}, 238}^{2}}}=0.0001
$$

Table 4.1: Peak areas of ${ }^{235} \mathrm{U}$ and ${ }^{238} \mathrm{U}$, determined by SIMS-measurement $(20 \times 20 \mu \mathrm{m}$, $32 \times 32$ pixel, 2547 scans, $300 \mathrm{~s}, \mathrm{Bi}^{3+}$ ).

\begin{tabular}{|c|c|c|c|l|c|l|}
\hline & $\mathbf{n}_{\mathbf{b}}$ & $\mathbf{u}\left(\mathbf{n}_{\mathbf{b}}\right)$ & $\mathbf{n}_{\mathbf{0}}$ & $\mathbf{u}\left(\mathbf{n}_{\mathbf{0}}\right)$ & $\mathbf{n}_{\mathbf{n}}$ & $\mathbf{u}\left(\mathbf{n}_{\mathbf{n}}\right)$ \\
\hline${ }^{235} \mathrm{U}$ & 2817 & 53,075 & 16 & 4,000 & 2801 & 53,23 \\
\hline${ }^{238} \mathrm{U}$ & 371011 & 609,107 & 178 & 13,342 & 370833 & 609,25 \\
\hline
\end{tabular}

\subsection{4 $\mu$-XRF}

Due to line overlapping (e.g. RhL, PdL, AgL) and background concentrations from sample carriers (86.39 wt $\% \mathrm{Al}, 11.03 \mathrm{wt} \% \mathrm{Pd}, 0.21 \mathrm{wt} \% \mathrm{Mn}, 0.2 \mathrm{wt} \% \mathrm{Fe}, 2.17 \mathrm{wt} \% \mathrm{Cu}$ ) and adhesive pads $(80.28 \mathrm{wt} \% \mathrm{Cu}, 8.6 \mathrm{wt} \% \mathrm{Pd}, 4.82 \mathrm{wt} \% \mathrm{Al}, 2.17 \mathrm{wt} \% \mathrm{Mn}, 2.32 \mathrm{wt} \% \mathrm{Fe}$, $1.08 \mathrm{wt} \% \mathrm{Si}, 0.54 \mathrm{wt} \% \mathrm{Ca}$ ), an exact quantification by $\mu$-XRF was not possible. Therefore, results in table 4.2 only show a qualitative comparison of the samples. Especially uranium could not be detected in the spot measurements.

Table 4.2 shows results of the $\mu$-XRF analyses where all mean values of three spot measurements per sample are given in wt\% with standard deviation. Elements that were quantified as zero for all three measurement positions are marked as n.d. (not detected) and the notion F and S stands for phase and sample number, respectively. F1S5 is the only soil sample in the entire sample sets. 
Table 4.2: Results of $\mu-\mathrm{XRF}$ analyses in $\mathrm{wt} \%$ ( $\mathrm{F}=$ sampling phase; $\mathrm{S}=$ sample number).

\begin{tabular}{|c|c|c|c|c|c|c|c|c|c|c|c|c|c|c|c|}
\hline & F1S1 & F1S2 & F1S3 & F1S4 & F1S5 & F2S1 & F2S2 & F2S3 & F2S4 & F2S5 & F2S1 & F3S2 & F3S3 & F3S4 & F3S5 \\
\hline $\begin{array}{c}\mathrm{Na} \\
\mathrm{K}\end{array}$ & $\begin{array}{c}6.16 \pm \\
0.76\end{array}$ & $\begin{array}{c}3.85 \pm \\
0.82\end{array}$ & $\begin{array}{c}1.17 \pm \\
2.03\end{array}$ & n.d. & $\begin{array}{c}5.41 \pm \\
0.93\end{array}$ & $\begin{array}{c}6.17 \pm \\
1.92\end{array}$ & $\begin{array}{c}4.26 \pm \\
0.30\end{array}$ & $\begin{array}{c}5.27 \pm \\
1.04\end{array}$ & n.d. & $\begin{array}{c}5.34 \pm \\
0.51\end{array}$ & $\begin{array}{c}2.50 \pm \\
0.77\end{array}$ & $\begin{array}{c}3.54 \pm \\
1.67\end{array}$ & $\begin{array}{c}3.90 \pm \\
0.35\end{array}$ & $\begin{array}{c}5.78 \pm \\
1.71\end{array}$ & $\begin{array}{c}2.72 \pm \\
1.56\end{array}$ \\
\hline $\begin{array}{l}\mathrm{Al} \\
\mathrm{K}\end{array}$ & $\begin{array}{c}15.65 \pm \\
0.28\end{array}$ & $\begin{array}{c}11.67 \pm \\
1.22\end{array}$ & $\begin{array}{c}4.10 \pm \\
3.60\end{array}$ & n.d. & $\begin{array}{c}14.92 \pm \\
1.06\end{array}$ & $\begin{array}{c}8.43 \pm \\
2.80\end{array}$ & $\begin{array}{c}6.85 \pm \\
0.70\end{array}$ & $\begin{array}{c}16.43 \pm \\
0.87\end{array}$ & $\begin{array}{c}1.45 \pm \\
0.90\end{array}$ & $\begin{array}{c}15.44 \pm \\
0.35\end{array}$ & $\begin{array}{c}8.81 \pm \\
5.30\end{array}$ & $\begin{array}{c}10.30 \pm \\
0.82\end{array}$ & $\begin{array}{c}9.08 \pm \\
2.41\end{array}$ & $\begin{array}{c}9.49 \pm \\
2.91\end{array}$ & $\begin{array}{c}12.03 \pm \\
0.56\end{array}$ \\
\hline $\mathrm{SiK}$ & $\begin{array}{c}65.83 \pm \\
0.94\end{array}$ & $\begin{array}{c}43.46 \pm \\
5.77\end{array}$ & $\begin{array}{c}51.82 \pm \\
26.03\end{array}$ & $\begin{array}{c}28.29 \pm \\
5.15\end{array}$ & $\begin{array}{c}65.18 \pm \\
0.32\end{array}$ & $\begin{array}{c}75.01 \pm \\
3.92\end{array}$ & $\begin{array}{c}76.60 \pm \\
0.94\end{array}$ & $\begin{array}{c}65.01 \pm \\
1.50\end{array}$ & $\begin{array}{c}36.41 \pm \\
7.71\end{array}$ & $\begin{array}{c}63.37 \pm \\
2.30\end{array}$ & $\begin{array}{c}73.70 \pm \\
10.25\end{array}$ & $\begin{array}{c}70.58 \pm \\
2.02\end{array}$ & $\begin{array}{c}72.65 \pm \\
3.56\end{array}$ & $\begin{array}{c}74.55 \pm \\
0.61\end{array}$ & $\begin{array}{c}63.71 \pm \\
11.32\end{array}$ \\
\hline P K & n.d. & n.d. & $\begin{array}{c}9.76 \pm \\
6.75\end{array}$ & $\begin{array}{c}21.88 \pm \\
2.02\end{array}$ & n.d. & n.d. & n.d. & n.d. & $\begin{array}{c}18.77 \pm \\
1.91\end{array}$ & n.d. & $\begin{array}{c}12.69 \pm \\
6.85\end{array}$ & $\begin{array}{c}8.71 \pm \\
4.16\end{array}$ & $\begin{array}{c}8.84 \pm \\
1.25\end{array}$ & $\begin{array}{c}4.91 \pm \\
3.18\end{array}$ & $\begin{array}{c}6.93 \pm \\
5.18\end{array}$ \\
\hline $\begin{array}{c}\mathrm{Pd} \\
\mathrm{L}\end{array}$ & $\begin{array}{c}0.77 \pm \\
1.33\end{array}$ & $\begin{array}{c}2.90 \pm \\
2.06\end{array}$ & n.d. & n.d. & n.d. & $\begin{array}{c}5.63 \pm \\
3.88\end{array}$ & $\begin{array}{c}6.20 \pm \\
1.25\end{array}$ & $\begin{array}{c}2.78 \pm \\
1.02\end{array}$ & n.d. & $\begin{array}{c}2.19 \pm \\
1.55\end{array}$ & $\begin{array}{c}0.39 \pm \\
0.39\end{array}$ & $\begin{array}{c}1.26 \pm \\
1.08\end{array}$ & $\begin{array}{c}1.41 \pm \\
0.61\end{array}$ & $\begin{array}{c}2.80 \pm \\
1.08\end{array}$ & $\begin{array}{c}5.41 \pm \\
8.46\end{array}$ \\
\hline $\begin{array}{l}\mathrm{K} \\
\mathrm{K}\end{array}$ & $\begin{array}{c}2.88 \pm \\
0.46\end{array}$ & $\begin{array}{c}1.86 \pm \\
1.18\end{array}$ & $\begin{array}{c}0.04 \pm \\
0.07\end{array}$ & n.d. & $\begin{array}{c}2.59 \pm \\
0.98\end{array}$ & $\begin{array}{c}0.91 \pm \\
0.50\end{array}$ & $\begin{array}{c}0.33 \pm \\
0.36\end{array}$ & $\begin{array}{c}5.01 \pm \\
0.54\end{array}$ & $\begin{array}{c}9.10 \pm \\
1.11\end{array}$ & $\begin{array}{c}6.07 \pm \\
1.45\end{array}$ & $\begin{array}{c}0.06 \pm \\
0.06\end{array}$ & $\begin{array}{c}0.35 \pm \\
0.14\end{array}$ & $\begin{array}{c}0.28 \pm \\
0.07\end{array}$ & $\begin{array}{c}0.55 \pm \\
0.82\end{array}$ & $\begin{array}{c}0.70 \pm \\
1.05\end{array}$ \\
\hline $\begin{array}{l}\mathrm{Ca} \\
\mathrm{K}\end{array}$ & $\begin{array}{c}5.98 \pm \\
0.96\end{array}$ & $\begin{array}{c}27.22 \pm \\
7.49\end{array}$ & $\begin{array}{c}7.78 \pm \\
3.88\end{array}$ & $\begin{array}{c}8.64 \pm \\
1.75\end{array}$ & $\begin{array}{c}6.40 \pm \\
2.30\end{array}$ & $\begin{array}{c}0.09 \pm \\
0.11\end{array}$ & $\begin{array}{c}0.05 \pm \\
0.03\end{array}$ & $\begin{array}{c}0.10 \pm \\
0.01\end{array}$ & n.d. & $\begin{array}{c}0.30 \pm \\
0.52\end{array}$ & $\begin{array}{c}0.05 \pm \\
0.06\end{array}$ & $\begin{array}{c}0.12 \pm \\
0.06\end{array}$ & $\begin{array}{c}0.10 \pm \\
0.02\end{array}$ & $\begin{array}{c}0.05 \pm \\
0.04\end{array}$ & $\begin{array}{c}0.17 \pm \\
0.08\end{array}$ \\
\hline TiK & $\begin{array}{c}0.09 \pm \\
0.02\end{array}$ & $\begin{array}{c}0.46 \pm \\
0.77\end{array}$ & n.d. & n.d. & $\begin{array}{c}0.15 \pm \\
0.01\end{array}$ & $\begin{array}{c}0.13 \pm \\
0.02\end{array}$ & $\begin{array}{c}0.29 \pm \\
0.09\end{array}$ & $\begin{array}{c}0.25 \pm \\
0.05\end{array}$ & n.d. & $\begin{array}{c}0.22 \pm \\
0.04\end{array}$ & $\begin{array}{c}0.22 \pm \\
0.11\end{array}$ & $\begin{array}{c}2.07 \pm \\
1.65\end{array}$ & $\begin{array}{c}0.98 \pm \\
0.05\end{array}$ & $\begin{array}{c}0.84 \pm \\
0.48\end{array}$ & $\begin{array}{c}4.22 \pm \\
5.68\end{array}$ \\
\hline $\begin{array}{c}\mathrm{Mn} \\
\mathrm{K}\end{array}$ & $\begin{array}{c}0.05 \pm \\
0.04\end{array}$ & $\begin{array}{c}0.14 \pm \\
0.06\end{array}$ & n.d. & n.d. & $\begin{array}{c}0.14 \pm \\
0.12\end{array}$ & $\begin{array}{c}0.65 \pm \\
0.15\end{array}$ & $\begin{array}{c}0.59 \pm \\
0.21\end{array}$ & $\begin{array}{c}0.99 \pm \\
0.19\end{array}$ & $\begin{array}{c}4.13 \pm \\
1.24\end{array}$ & $\begin{array}{c}1.80 \pm \\
1.33\end{array}$ & $\begin{array}{c}1.42 \pm \\
0.92\end{array}$ & $\begin{array}{c}2.94 \pm \\
0.49\end{array}$ & $\begin{array}{c}2.67 \pm \\
0.32\end{array}$ & $\begin{array}{c}1.23 \pm \\
0.92\end{array}$ & $\begin{array}{c}2.48 \pm \\
1.41\end{array}$ \\
\hline $\begin{array}{l}\mathrm{Fe} \\
\mathrm{K}\end{array}$ & $\begin{array}{c}0.95 \pm \\
0.26\end{array}$ & $\begin{array}{c}3.05 \pm \\
2.66\end{array}$ & $\begin{array}{c}6.12 \pm \\
3.59\end{array}$ & $\begin{array}{c}3.47 \pm \\
0.58\end{array}$ & $\begin{array}{c}1.44 \pm \\
0.36\end{array}$ & $\begin{array}{c}2.95 \pm \\
0.32\end{array}$ & $\begin{array}{c}4.76 \pm \\
0.90\end{array}$ & $\begin{array}{c}3.77 \pm \\
0.44\end{array}$ & $\begin{array}{c}1.84 \pm \\
0.96\end{array}$ & $\begin{array}{c}3.39 \pm \\
0.76\end{array}$ & n.d. & $\begin{array}{c}0.10 \pm \\
0.11\end{array}$ & $\begin{array}{c}0.05 \pm \\
0.03\end{array}$ & $\begin{array}{c}0.02 \pm \\
0.03\end{array}$ & $\begin{array}{c}0.00 \pm \\
0.01\end{array}$ \\
\hline
\end{tabular}




\begin{tabular}{|c|c|c|c|c|c|c|c|c|c|c|c|c|c|c|c|}
\hline $\begin{array}{l}\mathrm{Cu} \\
\mathrm{K}\end{array}$ & $\begin{array}{c}1.51 \pm \\
1.31\end{array}$ & $\begin{array}{c}3.41 \pm \\
0.66\end{array}$ & $\begin{array}{c}0.95 \pm \\
0.18\end{array}$ & $\begin{array}{c}0.45 \pm \\
0.31\end{array}$ & $\begin{array}{c}3.69 \pm \\
0.61\end{array}$ & $\begin{array}{c}0.03 \pm \\
0.01\end{array}$ & $\begin{array}{c}0.07 \pm \\
0.02\end{array}$ & $\begin{array}{c}0.03 \pm \\
0.03\end{array}$ & n.d. & n.d. & n.d. & n.d. & n.d. & n.d. & $\begin{array}{c}0.78 \pm \\
1.35\end{array}$ \\
\hline $\begin{array}{l}\mathrm{Cr} \\
\mathrm{K}\end{array}$ & $\begin{array}{c}0.03 \pm \\
0.01\end{array}$ & n.d. & n.d. & n.d. & $\begin{array}{c}0.06 \pm \\
0.02\end{array}$ & n.d. & n.d. & $\begin{array}{c}0.35 \pm \\
0.60\end{array}$ & $\begin{array}{c}2.63 \pm \\
1.39\end{array}$ & n.d. & n.d. & n.d. & n.d. & $\begin{array}{c}0.03 \pm \\
0.05\end{array}$ & $\begin{array}{c}0.59 \pm \\
1.03\end{array}$ \\
\hline $\begin{array}{l}\text { Th } \\
\text { L }\end{array}$ & n.d. & $\begin{array}{c}0.29 \pm \\
0.50\end{array}$ & $\begin{array}{c}1.12 \pm \\
0.54\end{array}$ & $\begin{array}{c}4.89 \pm \\
2.20\end{array}$ & n.d. & n.d. & n.d. & n.d. & $\begin{array}{c}12.38 \pm \\
3.05\end{array}$ & $\begin{array}{c}1.45 \pm \\
0.17\end{array}$ & n.d. & n.d. & n.d. & n.d. & n.d. \\
\hline $\begin{array}{c}\mathrm{Ce} \\
\mathrm{L}\end{array}$ & n.d. & $\begin{array}{c}1.51 \pm \\
1.37\end{array}$ & $\begin{array}{c}8.18 \pm \\
5.83\end{array}$ & $\begin{array}{c}16.15 \pm \\
2.51\end{array}$ & n.d. & n.d. & n.d. & n.d. & $\begin{array}{c}5.60 \pm \\
1.50\end{array}$ & $\begin{array}{c}0.36 \pm \\
0.36\end{array}$ & n.d. & n.d. & n.d. & n.d. & n.d. \\
\hline $\begin{array}{c}\mathrm{La} \\
\mathrm{L}\end{array}$ & n.d. & $\begin{array}{c}0.12 \pm \\
0.21\end{array}$ & $\begin{array}{c}3.20 \pm \\
2.23\end{array}$ & $\begin{array}{c}7.44 \pm \\
0.97\end{array}$ & n.d. & n.d. & n.d. & n.d. & $\begin{array}{c}1.09 \pm \\
0.19\end{array}$ & $\begin{array}{c}0.15 \pm \\
0.10\end{array}$ & n.d. & n.d. & n.d. & n.d. & n.d. \\
\hline S K & n.d. & $\begin{array}{c}0.08 \pm \\
0.14\end{array}$ & $\begin{array}{c}3.63 \pm \\
4.98\end{array}$ & $\begin{array}{c}1.85 \pm \\
0.86\end{array}$ & $\begin{array}{c}0.00 \pm \\
0.01\end{array}$ & n.d. & n.d. & n.d. & $\begin{array}{c}6.57 \pm \\
1.12\end{array}$ & n.d. & n.d. & $\begin{array}{c}0.00 \pm \\
0.01\end{array}$ & $\begin{array}{c}0.03 \pm \\
0.06\end{array}$ & n.d. & n.d. \\
\hline $\begin{array}{c}\mathrm{Ag} \\
\mathrm{L}\end{array}$ & n.d. & n.d. & $\begin{array}{c}4.28 \pm \\
2.69\end{array}$ & $\begin{array}{c}6.87 \pm \\
0.40\end{array}$ & n.d. & n.d. & n.d. & n.d. & $\begin{array}{c}6.57 \pm \\
1.12\end{array}$ & n.d. & n.d. & n.d. & n.d. & n.d. & n.d. \\
\hline $\mathrm{PtL}$ & n.d. & n.d. & $\begin{array}{c}0.23 \pm \\
0.25\end{array}$ & n.d. & n.d. & n.d. & n.d. & n.d. & n.d. & n.d. & n.d. & n.d. & n.d. & n.d. & n.d. \\
\hline $\begin{array}{c}\mathrm{Hg} \\
\mathrm{L}\end{array}$ & n.d. & n.d. & $\begin{array}{c}0.19 \pm \\
0.33\end{array}$ & n.d. & n.d. & n.d. & n.d. & n.d. & n.d. & n.d. & n.d. & n.d. & n.d. & n.d. & n.d. \\
\hline $\begin{array}{l}\mathrm{Ni} \\
\mathrm{K}\end{array}$ & n.d. & n.d. & $\begin{array}{c}0.04 \pm \\
0.07\end{array}$ & n.d. & n.d. & n.d. & n.d. & n.d. & n.d. & n.d. & n.d. & n.d. & n.d. & n.d. & n.d. \\
\hline $\begin{array}{c}\text { As } \\
\mathrm{K}\end{array}$ & n.d. & n.d. & n.d. & $\begin{array}{c}0,05 \pm \\
0.08\end{array}$ & n.d. & n.d. & n.d. & n.d. & $\begin{array}{c}0.03 \pm \\
0.06\end{array}$ & n.d. & n.d. & n.d. & n.d. & n.d. & n.d. \\
\hline
\end{tabular}




\begin{tabular}{|c|c|c|c|c|c|c|c|c|c|c|c|c|c|c|c|}
\hline $\begin{array}{l}\mathrm{Se} \\
\mathrm{K}\end{array}$ & n.d. & n.d. & n.d. & n.d. & n.d. & n.d. & n.d. & n.d. & n.d. & n.d. & $\begin{array}{c}0.05 \pm \\
0.09\end{array}$ & n.d. & n.d. & n.d. & n.d. \\
\hline $\begin{array}{c}\mathrm{Ba} \\
\mathrm{L}\end{array}$ & n.d. & n.d. & n.d. & n.d. & n.d. & n.d. & n.d. & n.d. & n.d. & n.d. & $\begin{array}{c}0.15 \pm \\
0.26\end{array}$ & n.d. & n.d. & $\begin{array}{c}0.01 \pm \\
0.02\end{array}$ & $\begin{array}{r}0.08 \pm \\
0.14\end{array}$ \\
\hline $\begin{array}{l}\text { W } \\
\mathrm{L}\end{array}$ & n.d. & n.d. & n.d. & n.d. & n.d. & n.d. & n.d. & n.d. & n.d. & n.d. & n.d. & n.d. & n.d. & $\begin{array}{c}0.24 \pm \\
0.14\end{array}$ & n.d. \\
\hline $\begin{array}{c}\mathrm{Nd} \\
\mathrm{L}\end{array}$ & n.d. & n.d. & n.d. & n.d. & n.d. & n.d. & n.d. & n.d. & n.d. & n.d. & n.d. & n.d. & n.d. & n.d. & $\begin{array}{r}0.18 \pm \\
0.32\end{array}$ \\
\hline
\end{tabular}


Elemental mappings enabled the visualization of particle distributions, e.g. for $\mathrm{K}, \mathrm{Ca}, \mathrm{Fe}$, and Ti. But the localization of uraniferous particles was not possible with the mentioned parameters. Using long measurement periods per spot, only uranium, thorium, and radium background signals with an average maximum intensity of $10 \mathrm{cps}$ were obtained. Uraniferous particles can possibly be located using optimized measurement periods (long enough to obtain a uranium signal and short enough to eliminate a uranium background signal) and smaller spot distances.

The minimum required uranium concentrations and particle sizes for a localization and quantification by $\mu$-XRF for this type of soil and rock samples should be investigated in further studies.

\subsubsection{Powder XRD}

The rock samples collected from Kabul, Afghanistan, are mainly composed of aluminum silicate minerals, such as albite, mica, and microcline, with minor phases of other silicate and/or phosphate minerals.

The thorium detected in some samples is primarily in the form of mixed phosphate silicate minerals containing $\mathrm{Ca}, \mathrm{RE}$, and Th (possibly also $\mathrm{U}$ ), such as cheralite. This also means that the thorium in the collected rocks is likely to originate from natural deposits, not from artificial sources, such as weapons. (See annex 3 for diffractograms)

\subsubsection{SEM-EDX}

The soil sample measured with SEM in BSE mode revealed a number of heavy particles existing in the sample, further analyzing these particles by EDX shows that there exist uranium and thorium in significant amounts, where the thorium peak is higher than the one for uranium which can be considered as a further verification for our results of other methods indicating higher thorium concentration. Fig.4.4a and Fig.4.4b shows the BSE based SEM image and EDX graph of the measured soil sample. 


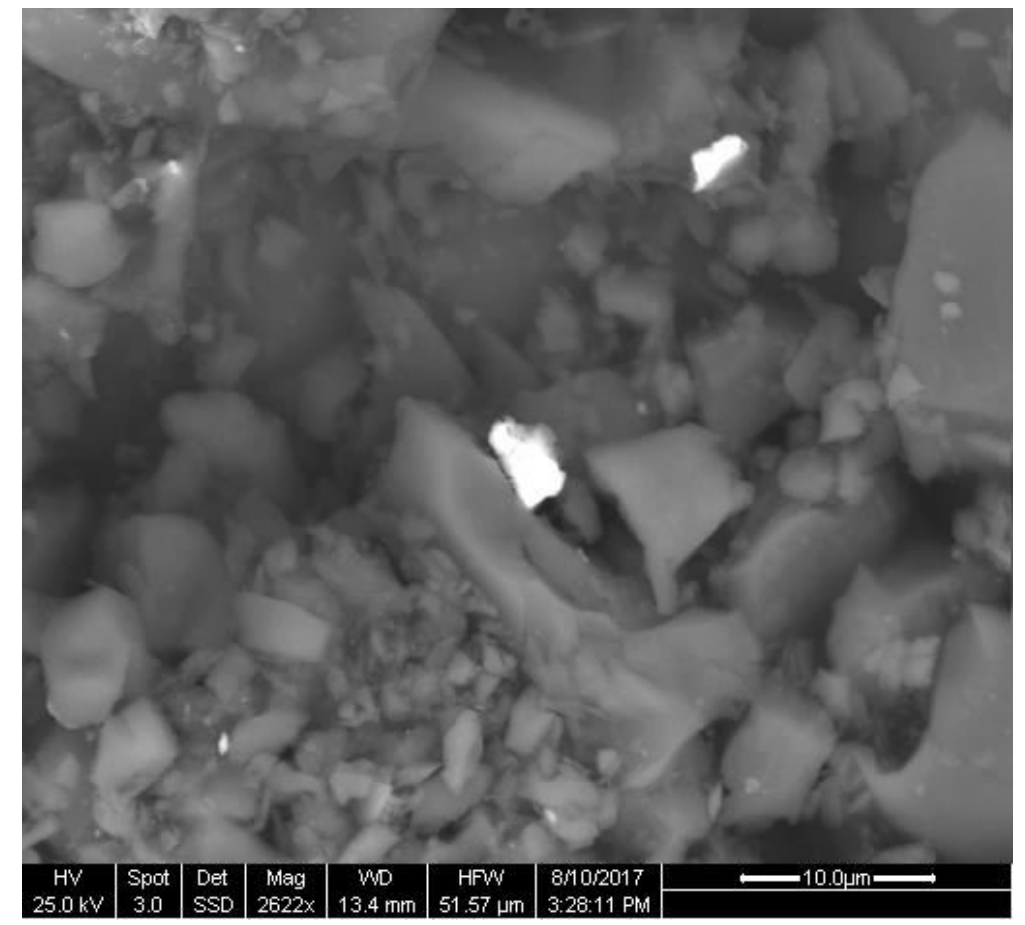

Fig. $4.4 \mathrm{a}$

Label A:

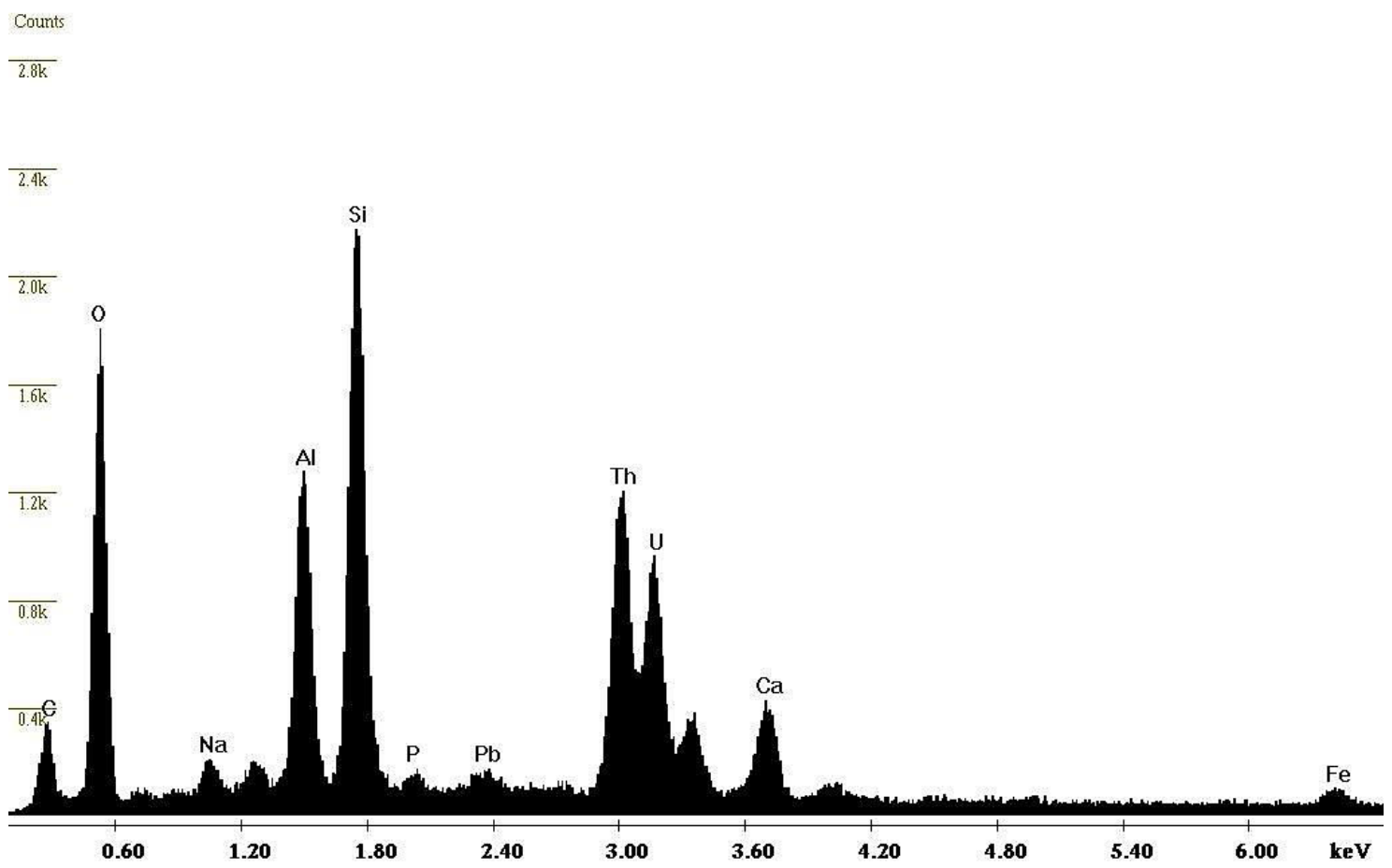

Fig. 4.4b 


\subsection{Water}

\subsubsection{ICP-MS and ICP-OES results}

The values measured in first sampling phase differ from one location to the other. Table 4.3 and Table 4.4 show the concentrations of different elements determined by ICP-MS and ICP-OES respectively. Samples used in this study were all drinking as well as allpurpose waters. Thus, for evaluation and calculation, international standards for drinking waters were considered.

Table 4.3: Element concentration measured by ICP-MS [ppm]

\begin{tabular}{|c|c|c|c|c|c|c|c|c|}
\hline \multirow{2}{*}{ 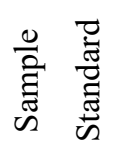 } & \multicolumn{8}{|c|}{ Element concentration measured by ICP-MS [ppm] } \\
\hline & Zinc & Arsenic & Nickel & Manganese & Copper & Chromium & Barium & Aluminum \\
\hline 1 & 0.14 & 0.003 & 0.002 & 0.001 & 0.002 & 0.005 & 0.05 & 0.032 \\
\hline 2 & 0.03 & 0.004 & 0.002 & 0.007 & 0.003 & 0.005 & 0.05 & 0.11 \\
\hline 3 & 0.08 & 0.004 & 0.002 & 0.006 & 0.003 & 0.005 & 0.05 & 0.13 \\
\hline 4 & 0.001 & 0.005 & 0.002 & 0.002 & 0.002 & 0.004 & 0.03 & 0.10 \\
\hline 5 & 0.0005 & 0.002 & 0.01 & 0.001 & 0.002 & 0.003 & 0.03 & 0.11 \\
\hline 6 & 0.003 & 0.002 & 0.01 & 0.001 & 0.002 & 0.003 & 0.03 & 0.13 \\
\hline 7 & 0.001 & 0.002 & 0.01 & 0.001 & 0.004 & 0.003 & 0.02 & 0.1 \\
\hline 8 & 0.0003 & 0.001 & 0.002 & 0.0008 & 0.003 & 0.002 & 0.08 & 0.23 \\
\hline
\end{tabular}

Elements which could not be measured by ICP-MS due to interferences were measured by ICP-OES.

Table 4.4: Element concentration of the samples from the first phase measured by ICPOES [ppm]

\begin{tabular}{|l|c|c|c|c|c|c|c|}
\hline \multirow{2}{*}{$\begin{array}{c}\text { 岕 } \\
\text { 岕 }\end{array}$} & \multicolumn{7}{|c|}{ Element concentration measured by ICP-OES [ppm] } \\
\cline { 2 - 8 } & $\mathrm{Na}$ & $\mathrm{Ca}$ & $\mathrm{Fe}$ & $\mathrm{K}$ & $\mathrm{Pb}$ & $\mathrm{Mg}$ & $\mathrm{U}$ \\
\hline 1 & $36 \pm 1$ & $55 \pm 0.4$ & $0.00015 \pm 0.0001$ & $8 \pm 0.2$ & $0.0012 \pm 0.0002$ & $22 \pm 0.1$ & $0.0204 \pm 0.0117$ \\
\hline 2 & $55 . \pm 1$ & $63 \pm 0.3$ & $0.0002 \pm 0.0001$ & $11 \pm 0.4$ & $0.0009 \pm 0.0004$ & $36 \pm 0.1$ & $0.0229 \pm 0.0048$ \\
\hline 3 & $42 \pm 1$ & $57 \pm 0.4$ & $0.00055 \pm 0.0001$ & $8 \pm 0.2$ & $0.0011 \pm 0.0004$ & $26 \pm 0.1$ & $0.0177 \pm 0.0209$ \\
\hline 4 & $10 \pm 0.2$ & $41 \pm 0.4$ & $\mathrm{LDL}$ & $6 \pm 0.2$ & $0.0001 \pm 0.0002$ & $12 \pm 0.1$ & $0.0240 \pm 0.0277$ \\
\hline 5 & $99 \pm 0.4$ & $15 \pm 0.1$ & $0.0001 \pm 0$ & $11 \pm 0.2$ & $0.0005 \pm 0.0006$ & $103 \pm 0.00$ & $0.0094 \pm 0.023$ \\
\hline 6 & $97 \pm 0.0$ & $17 \pm 0.2$ & $0.00015 \pm 0.0001$ & $12 \pm 0.2$ & $0.0001 \pm 0.0003$ & $100 \pm 1$ & $0.0091 \pm 0.0039$ \\
\hline
\end{tabular}




\begin{tabular}{|l|c|c|c|c|c|c|c|}
\hline 7 & $96 \pm 0.3$ & $13 \pm 0.12$ & $0.00015 \pm 0$ & $12 \pm 0.2$ & $0.0002 \pm 0.0001$ & $101 \pm 0.3$ & $0.0100 \pm 0.013$ \\
\hline 8 & $64 \pm 0.5$ & $55 \pm 0.03$ & $0.00065 \pm 0.0002$ & $20 \pm 0.5$ & $0.0006 \pm 0.0003$ & $51 \pm 0.3$ & $0.0748 \pm 0.0186$ \\
\hline
\end{tabular}

The ICP-MS results for the second and third phase samples are shown in tables 4.5 and 4.6, respectively, where the acronym LDL stands for lower than detection limit.

Table 4.5: Element concentration of the samples from the second phase measured by ICPMS.

\begin{tabular}{|c|c|c|c|}
\hline Sample & $\mathrm{U}[\mathrm{ppb}]$ & $\mathrm{Th}[\mathrm{ppb}]$ & $\mathrm{Pb}[\mathrm{ppb}]$ \\
\hline 1 & $9 \pm 14$ & $154 \pm 7$ & LDL \\
\hline 2 & $21 \pm 17$ & $38 \pm 5$ & LDL \\
\hline 3 & $5 \pm 4$ & $70 \pm 44$ & LDL \\
\hline 4 & $4 \pm 5$ & $10 \pm 12$ & LDL \\
\hline 5 & $0.06 \pm 0.04$ & $2 \pm 0$ & LDL \\
\hline 6 & $9 \pm 7$ & $28 \pm 11$ & $2 \pm 5$ \\
\hline 7 & $5 \pm 1$ & $10 \pm 3$ & LDL \\
\hline 8 & $4 \pm 4$ & $4 \pm 1$ & LDL \\
\hline 9 & $4 \pm 3$ & $2 \pm 0$ & LDL \\
\hline 10 & $4 \pm 2$ & $2 \pm 0$ & LDL \\
\hline 11 & $5 \pm 4$ & $4 \pm 1$ & LDL \\
\hline 12 & $0.01 \pm 0.01$ & LDL & LDL \\
\hline 13 & $6 \pm 4$ & $24 \pm 19$ & LDL \\
\hline 14 & $2 \pm 2$ & $2 \pm 0$ & LDL \\
\hline 15 & $5 \pm 4$ & $10 \pm 3$ & LDL \\
\hline 16 & $7 \pm 5$ & $4 \pm 1$ & LDL \\
\hline 17 & $4 \pm 3$ & $14 \pm 14$ & LDL \\
\hline 18 & $4 \pm 2$ & $8 \pm 8$ & LDL \\
\hline 19 & $6 \pm 3$ & LDL & LDL \\
\hline 20 & $0.04 \pm 0.14$ & $2 \pm 0$ & LDL \\
\hline 21 & $1 \pm 2$ & $12 \pm 15$ & LDL \\
\hline 22 & $0.18 \pm 0.05$ & $4 \pm 6$ & LDL \\
\hline 23 & $10 \pm 3$ & $4 \pm 1$ & LDL \\
\hline
\end{tabular}


Table 4.6: Element concentration of the samples from the third phase measured by ICPMS.

\begin{tabular}{|c|c|c|c|}
\hline Sample & $\mathbf{U}$ [ppb] & Th [ppb] & Pb [ppb] \\
\hline 1 & $26 \pm 10$ & LDL & LDL \\
\hline 2 & $4 \pm 3$ & LDL & LDL \\
\hline 3 & $4 \pm 2$ & LDL & LDL \\
\hline 4 & $16 \pm 4$ & LDL & LDL \\
\hline 5 & $20 \pm 20$ & LDL & LDL \\
\hline 6 & $3 \pm 10$ & LDL & LDL \\
\hline 7 & $3 \pm 2$ & LDL & LDL \\
\hline 8 & $3 \pm 3.11$ & LDL & LDL \\
\hline 9 & $11 \pm 10$ & LDL & LDL \\
\hline 10 & $2 \pm 2$ & LDL & LDL \\
\hline 11 & $0.3 \pm 0.6$ & LDL & LDL \\
\hline 12 & $1 \pm 4$ & LDL & LDL \\
\hline 13 & $1 \pm 1$ & LDL & LDL \\
\hline 14 & $6 \pm 4$ & LDL & LDL \\
\hline 15 & $1 \pm 1$ & LDL & LDL \\
\hline 16 & $2 \pm 3$ & LDL & LDL \\
\hline 17 & $2 \pm 1$ & LDL & LDL \\
\hline 18 & $7 \pm 5$ & LDL & LDL \\
\hline 19 & $3 \pm 3$ & LDL & LDL \\
\hline 20 & $7 \pm 6$ & LDL & LDL \\
\hline
\end{tabular}

All samples of the first phase of measurements, show a lower concentration of uranium than the provisional guideline value (0.03 ppm) proposed by WHO (WHO, 2011c), except for sample number 8 , which was taken from an unconfined well and exhibited a concentration of about $0.07 \mathrm{ppm}$. In some of the samples aluminum and magnesium concentrations are also higher than proposed by AUWSSC (see annex 2), but they are still in the range of uncertainty and the permissible limit in the absence of alternate water. For the AUWSSC the main elements of concern in drinking water are aluminum, zinc, arsenic, and lead. 
Aluminum is supposed to be an essential element of human nutrition (Hathcock, 2012). The value envisaged by WHO and AUWSSC as a concentration standard for aluminum in drinking water is $0.2 \mathrm{ppm}$ (WHO, 2010a). Aluminium concentrations of the analysed water samples vary from 0.03 to $0.23 \mathrm{ppm}$, where the maximum value of 0.23 corresponds to sample number 8 number taken from an unconfined well in a village south east of Kabul.

Zinc is considered having a harmful effect on living organisms. Elevated intake of Zinc can cause copper deficiency in different age groups, which can be considered as malnutrition (Plum et al., 2010). The amount of zinc may differ from surface to sea and tap water. Due to substandard sanitary conditions, the level of zinc is higher in tap and sewer water. The threshold concentration of zinc in drinking water mentioned by WHO for giving water a bad taste and standard value proposed by AUWSSC is 3 ppm (WHO, 2003). In the samples measured in this study the concentration of zinc was far below the above mentioned guideline by WHO and AUWSSC; it ranged from 0.0003 to $0.13 \mathrm{ppm}$.

Arsenic can appear in water in organic and inorganic form, with inorganic arsenic compounds being the most probable form in drinking water and having a relatively high level of toxicity (WHO, 2010b). The provisional guideline value for arsenic in drinking water given by WHO and adopted by AUWSSC is 0.01 ppm (WHO, 2011a), while the concentration in this study varied from 0.001 to $0.003 \mathrm{ppm}$, which is clearly below the limit

Lead as a poisonous and most abundant heavy metal is considered highly toxic for human beings (Hunter, 2008). The provisional guideline value of lead in drinking water recommended by WHO and adopted by AUWSSC is 0.01 ppm (WHO, 2011b). Lead concentrations in our samples were far below this value, ranging from 0.006 to $0.0012 \mathrm{ppm}$.

Uranium is not considered as nutrient for humans and animals (Virginia et al., 2012), but when ingested it appears rapidly in the blood stream and associates itself with red blood cells (Karpas, 2014). The provisional guideline value for uranium in drinking water proposed by WHO and adopted by AUWSSC is $0.03 \mathrm{ppm}$ or $30 \mathrm{ppb}$ (WHO, 2011c). Uranium concentrations of our samples ranged between 0.01 to $26.1 \mathrm{ppb}$, which corresponds to sample number 12 and sample number 1 of the second and third phase, respectively. All of the samples measured in this study exhibited uranium concentrations below the recommended limit. 
Thorium: There is less information available on health effects of thorium on human beings in comparison to uranium, but studies on animals show that ingestion of massive amounts of thorium causes metal poisoning leading to death (Prasad, 2008). The proposed guidance level of thorium in drinking water is $0.1 \mathrm{ppb}$ (Boyle, 1982), while thorium concentration in our samples ranged between 2 and $154 \mathrm{ppb}$.

Radium as a decay product of uranium and thorium is also not necessary for living organisms and causes adverse health effects upon incorporation. Under acidic conditions, radium easily dissolves in groundwater. Extensive doses of radium cause bone cancer (Finkelstein et al., 1996). In our samples, no detectable amounts of radium were measured, this might be due to the different leaching behaviour of our water or the samples were not old enough to reach the secular equilibrium between the mother and daughter nuclides.

In the water samples we analysed, uranium and thorium were found in considerable amounts, as can be seen in Table 4.5. Uranium concentrations of all samples are still below the $30 \mathrm{ppb}$ guideline value proposed by WHO (WHO, 2011c). Thorium concentration can be as high as $100 \mathrm{ppm}$ in waters enriched with humic substances (Boyle, 1982). In the second phase of our study, the concentrations of one sample was as high as $154 \mathrm{ppb}$ (sample number 1), but with a relative high uncertainty. The water source at this location is in the vicinity of a sewage water reservoir and it is likely that there are veins and leakages from the reservoir to the well. This might have caused a change in $\mathrm{pH}$ of the water which might have led to higher solubility and increased concentration of thorium in the water (Kobets \& Pshinko, 2014), the solubility and pH correlation diagram is shown in Fig.4.5 (Neck et al., 2002). 


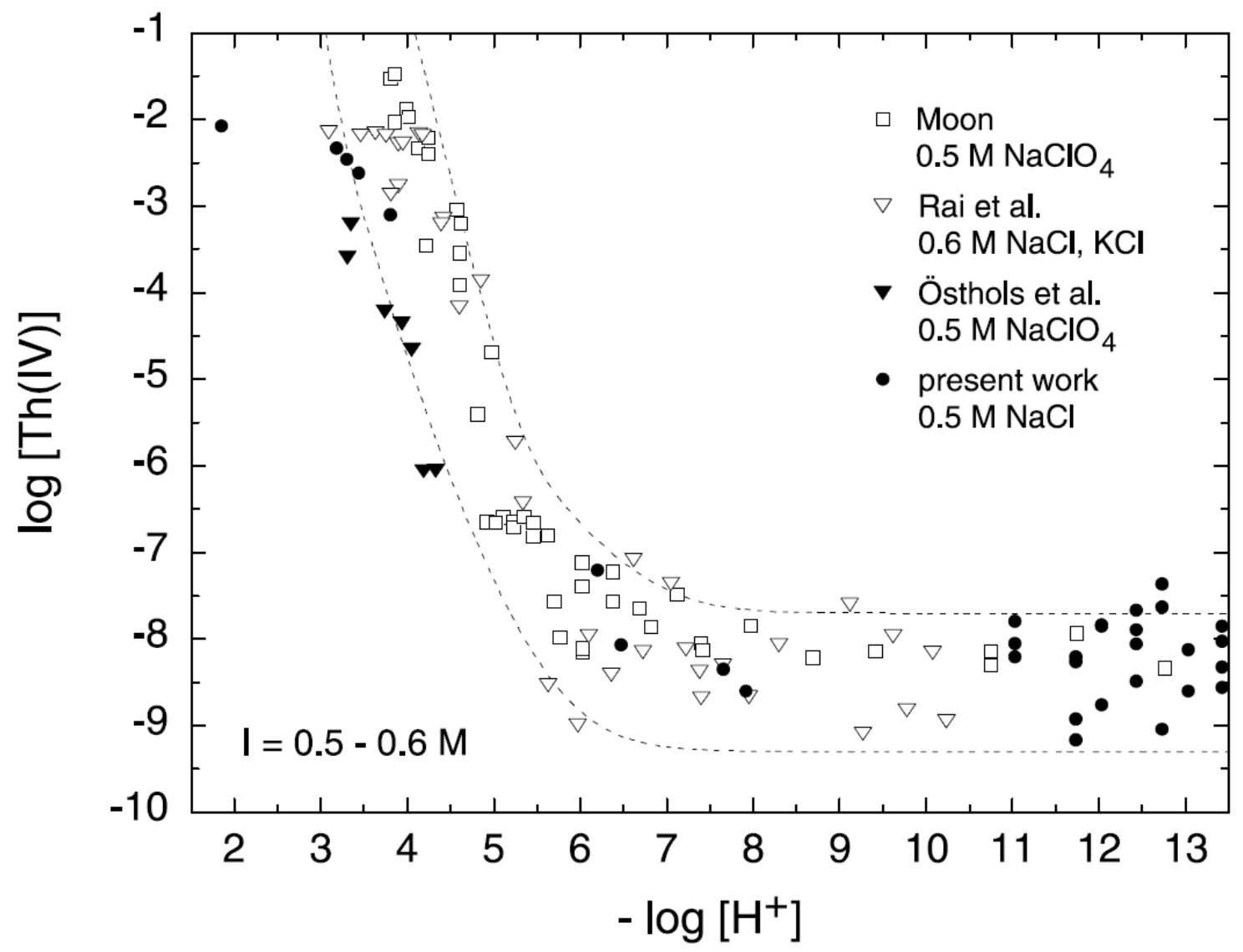

Fig.4.5 Solubility of amorphous Th (IV) hydroxide or hydrous oxide at I $=0.5-0.6 \mathrm{M}$ and $18-25{ }^{\circ} \mathrm{C}$

Lead concentrations of all samples were well below the WHO guideline values and, except for number 6 , also below the detection limit.

Results of the water sampled in the third sampling phase revealed concentrations of thorium and lead below detection limit (LDL; see Table 4.6). Only for uranium, considerable amounts were detected in the samples. However, also uranium concentrations are below the WHO guideline value of $30 \mathrm{ppb}$.

\subsection{Radon}

\subsubsection{Measurement results}

As the incident recording time was set to $10 \mathrm{~min}$, the data were summed up for six consecutive data points for an hourly interval count rate. The activity concentration was obtained from the count rate by multiplication with the calibration factors given by Karinda et al. (Karinda, 2009) . Uncertainties were calculated for the total integrated counts only. 
Due to low count rates, time resolved, e.g. hourly based, uncertainties are not meaningful. Due to limited access, the devices could neither be tested nor calibrated at the measurement sites prior to the sampling campaign. The effective dose was calculated using the following equation recommended by ICRP (ICRP, 1994b):

$$
\mathrm{H}_{\mathrm{Rn}}=\mathrm{A}_{\mathrm{Rn}} * \mathrm{~F} * \mathrm{t}_{\mathrm{exp}} * \mathrm{AR} * \mathrm{~d}_{\mathrm{Rn}} \quad 4.2
$$

where $H_{R n}$ is the annual effective dose in $S v, A_{R n}$ is the activity concentration in $B q / \mathrm{m}^{3}$, $\mathrm{F}$ is the dimensionless equilibrium factor of ${ }^{222} \mathrm{Rn}$ daughter decay chain (Note: because it was not possible to measure $F$, the standard value of 0.4 recommended for typical indoor environments was assumed (UNSCEAR, 2000)). $t_{\text {exp }}$ is the annual time period of indoor stay in hours (assumed here to be 4,380 hours; note that due to cultural difference in working and living regimes, the typical indoor stay for all the locations including working and living spaces in caves and basements investigated here was assumed to reach 12 hours per day). AR is the typical breath factor proposed by ICRP for a reference worker as $1.2 \mathrm{~m}^{3} / \mathrm{h}$ (ICRP, 1994a) and $\mathrm{d}_{\mathrm{Rn}}$ is the inhalation dose factor for radon $\left(7.7^{*} 10^{-9} \mathrm{~Sv} / \mathrm{Bq}\right)$. 
Table 4.7: Mean values of measured activities and dose for different locations of the first phase of the measurements.

\begin{tabular}{|c|c|c|c|c|}
\hline $\begin{array}{c}\text { Location/ } \\
\text { local name }\end{array}$ & $\begin{array}{c}\text { Average activity } \\
{\left[\mathrm{Bq} / \mathrm{m}^{3}\right]}\end{array}$ & Uncertainty $\left[\mathrm{Bq} / \mathrm{m}^{3}\right]$ & $\begin{array}{c}\text { Annual effective } \\
\text { dose }[\mathrm{mSv} / \mathrm{a}]\end{array}$ & $\begin{array}{c}\text { Uncertainty } \\
{[\mathrm{mSv} / \mathrm{a}]}\end{array}$ \\
\hline Sher Pacha basement & 6 & \pm 1 & 0.1 & \pm 0.02 \\
\hline Agha basement & 120 & \pm 10 & 1.9 & \pm 0.16 \\
\hline Karim 1 basement & 36 & \pm 4 & 0.6 & \pm 0.06 \\
\hline Karim 2 basement & 34 & \pm 4 & 0.5 & \pm 0.06 \\
\hline Haji Dost & 26 & \pm 6 & 0.4 & \pm 0.09 \\
\hline Gen Azumdin & 133 & \pm 16 & 2.1 & \pm 0.25 \\
\hline Qurban & 140 & \pm 15 & 2.2 & \pm 0.23 \\
\hline Maazudin & 35 & \pm 6 & 0.5 & \pm 0.09 \\
\hline
\end{tabular}


The Sher Pacha Karim 1 and Karim 2 basements have relatively good ventilation by having one entrance and two windows, whereas Agha basement has just one entrance from the corridor and no air exchange with open air. All of the caves had more air exchange possibility during the day as a fact of human activity and in the night, only mountain breeze could cause minor air exchange. The limited ventilation condition led to rather high radon levels. Keeping in mind the average activity concentration level as $300 \mathrm{~Bq} / \mathrm{m}^{3}$ corresponding to an annual effective dose of $10 \mathrm{mSv}$ recommended by the ICRP and the IAEA on the assumption of an annual occupancy of 7,000 $\mathrm{h}$ and an equilibrium factor of 0.4 for ${ }^{222} \mathrm{Rn}$ (IAEA, 2014b, 2014a; Cavallo et al., 1992), one can conclude that all measurement sites above have a lower concentration than the recommended level, and thus do not pose considerable risk of lung cancer originated from higher concentrations of radon.

The seasonal averages of the activity concentrations and annual effective doses for different locations of the second phase are shown in Table 4.8.

Table 4.8: Seasonal averages of the activity concentrations and annual effective doses of the second phase.

\begin{tabular}{|c|c|c|c|}
\hline Season & Location & $\begin{array}{l}\text { Average activity con- } \\
\text { centration }\left[\mathrm{Bq} / \mathrm{m}^{3}\right]\end{array}$ & $\begin{array}{c}\text { Annual effective } \\
\text { dose }[\mathrm{mSv} / \mathrm{a}]\end{array}$ \\
\hline \multirow{8}{*}{ 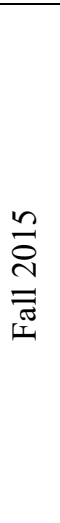 } & Mirza Room & $36.2 \pm 0.1$ & $0.6 \pm 0.001$ \\
\hline & Abobaker Basement & $40.3 \pm 0.1$ & $0.7 \pm 0.001$ \\
\hline & AAEHC Basement & $2087.3 \pm 16.8$ & $33.8 \pm 0.18$ \\
\hline & Samay Basement & $43.5 \pm 0.1$ & $0.7 \pm 0.001$ \\
\hline & Abobaker Room & $33.2 \pm 0.2$ & $0.6 \pm 0.18$ \\
\hline & Mirza Basement & $136.1 \pm 0.4$ & $2.2 \pm 0.004$ \\
\hline & AAEHC Hall & $28.8 \pm 0.1$ & $0.5 \pm 0.001$ \\
\hline & Samay Room & $38.6 \pm 0.1$ & $0.6 \pm 0.001$ \\
\hline \multirow{5}{*}{ 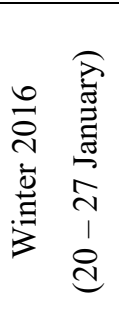 } & Mirza Room & $31.9 \pm 0.1$ & $0.5 \pm 0.002$ \\
\hline & Abobaker Basement & $127.9 \pm 0.1$ & $2.0 \pm 0.003$ \\
\hline & AAEHC Basement & $1959.9 \pm 16.2$ & $31.8 \pm 0.27$ \\
\hline & Samay Basement & $86.3 \pm 0.1$ & $1.4 \pm 0.003$ \\
\hline & Abobaker Room & $68.3 \pm 0.1$ & $1.1 \pm 0.002$ \\
\hline
\end{tabular}




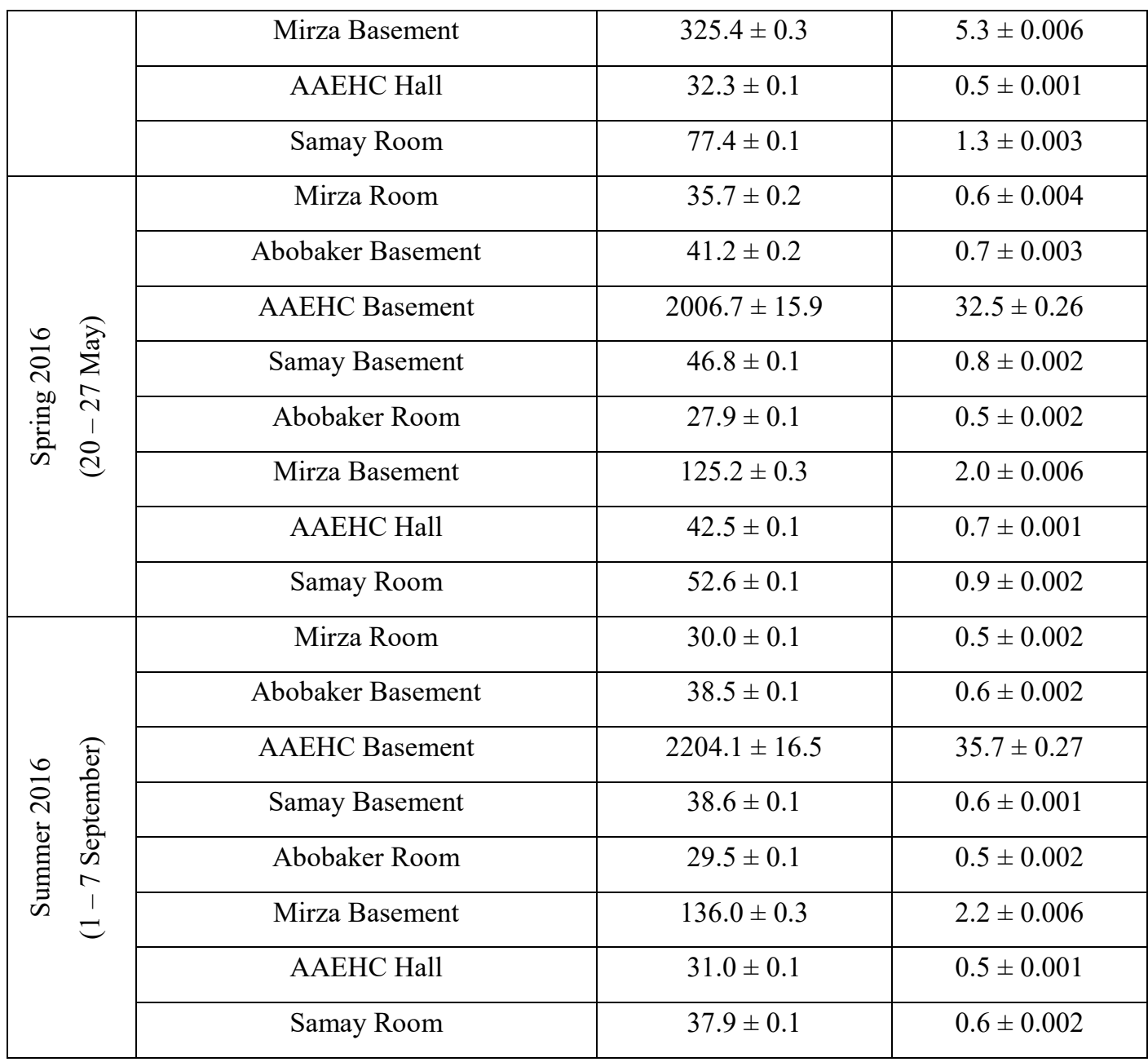

Table 4.9: Annual averages of the activity concentration and the effective dose for different locations of the second phase measurements.

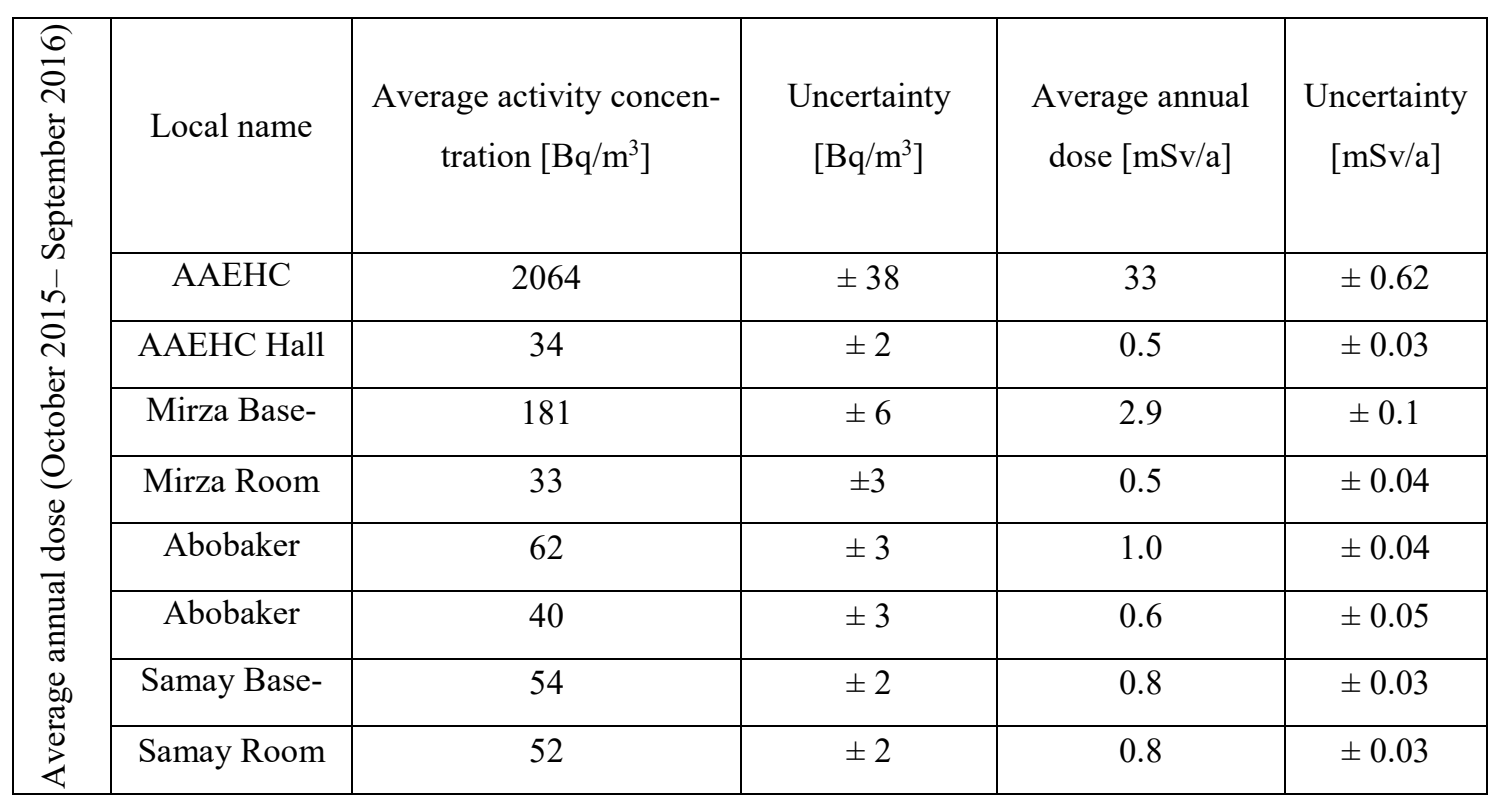


As it can be seen in table 4.9, except for the AAEHC basement, all other locations show an average activity well below the level of $300 \mathrm{~Bq} / \mathrm{m}^{3}$ proposed by IAEA. As far as ventilation is concerned the AAEHC basement has poor ventilation and the only entrance of the basements is opened and closed only about two to six times a day, which does not allow for sufficient air circulation and exchange and makes it a highly radon concentrated environment. The opening frequency of this basement decreases with decreasing temperature and as expected, the radon level should increase. The contrasting observation of decreasing concentration in winter is readily explained by the use of a wood-fired stove for heating. The burning fire causes additional air circulation through the chimney allowing also radon to escape. Mainly cleaning staff uses this basement room. The seasonal activity concentration for the AAEHC basement is shown in Fig.4.6.

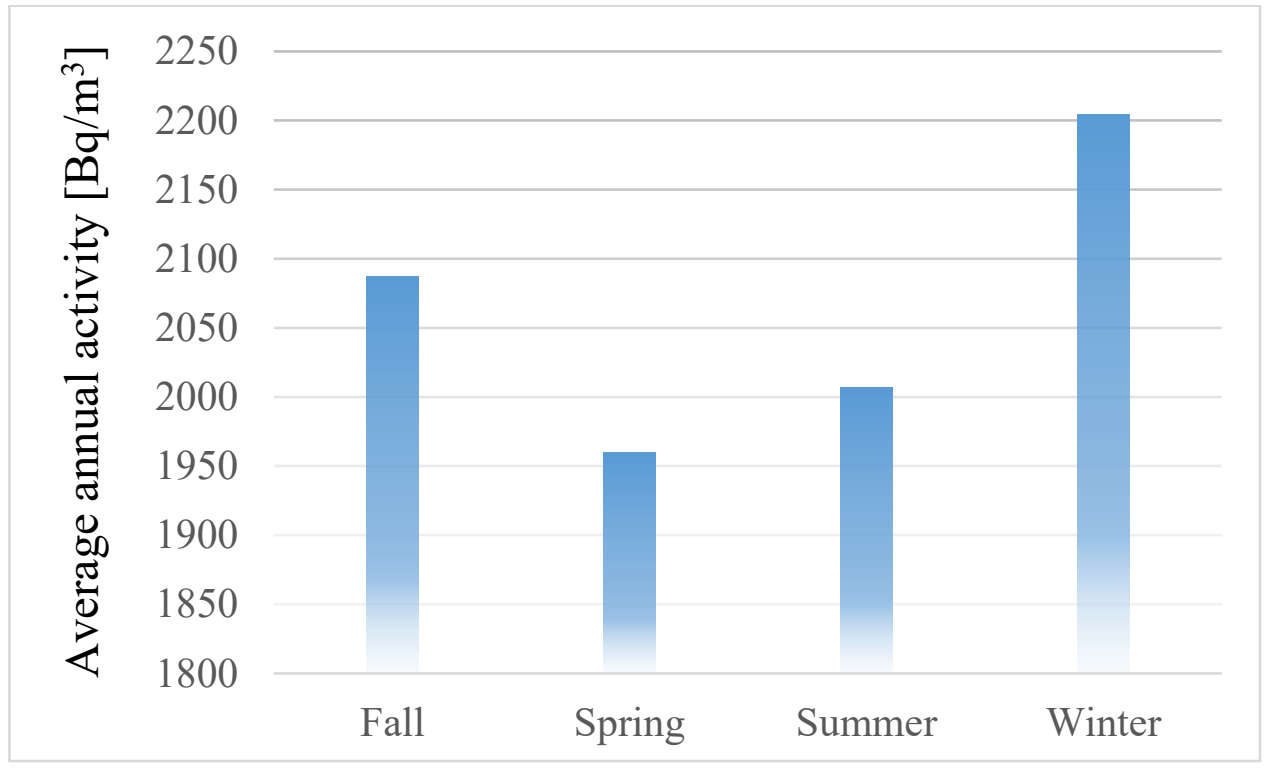

Fig.4.6 seasonal activity concentration for the AAEHC basement

The AAEHC hall has no electrical ventilation system but is equipped with an air ventilator fan, which has an air exchanger pipe placed outside the window. It has one entrance and two small windows, which are opened from three to five times a day, and this space is mostly used as working office. The Abobaker basement has one entrance and a window, the entrance is opened two to four times a day and the window remains blocked almost all the time. This space is used as sleeping and living room. The Abobaker room is a living room having two big windows and one entrance. The Mirza basement and room have an entrance and a window, the basement window is smaller than that of the 
living room but both basement and room are used as living rooms. Samay basement has one entrance while the living room has two entrances and two windows, one entrance is opened to the corridor and another to the balcony, and it is used as regular living room, while the basement is used as kitchen and baking space on regular basis. In all cases except the Samay basement the ventilation situation gets poor as the temperature decreases. Keeping the annual indoor occupancy hours as 4,380 (12 hours/day) and comparing these values to those for the countries in the neighbourhood, it can be concluded that except the AAEHC basements, all other locations should not be considered as high risk areas of radon originating lung cancer. The reason that the IAEA recommendation and standards were chosen for comparisons in this section is that they cover a wider range of area in their studies than ICRP which is mostly focused on Europe. A daily based radon concentration distribution for the fall season measurements of AAEHC basement is given in Fig.4.7.

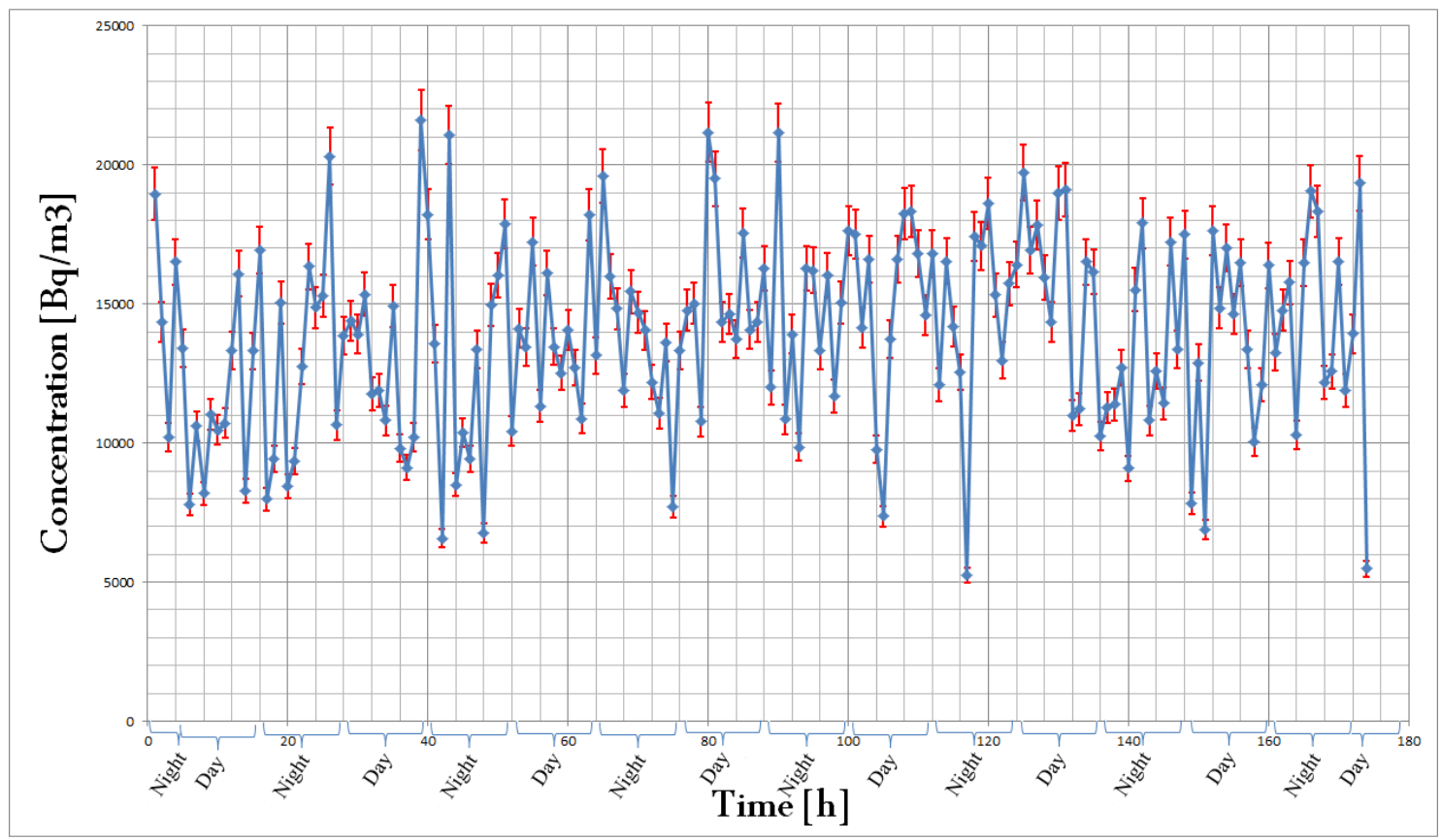

Fig. 4.7: Hourly measurement of the fall season at AAEHC basement with the determined hours for day and night. 
The difference in concentration between the basements and rooms/hall is shown in Fig.4.8.

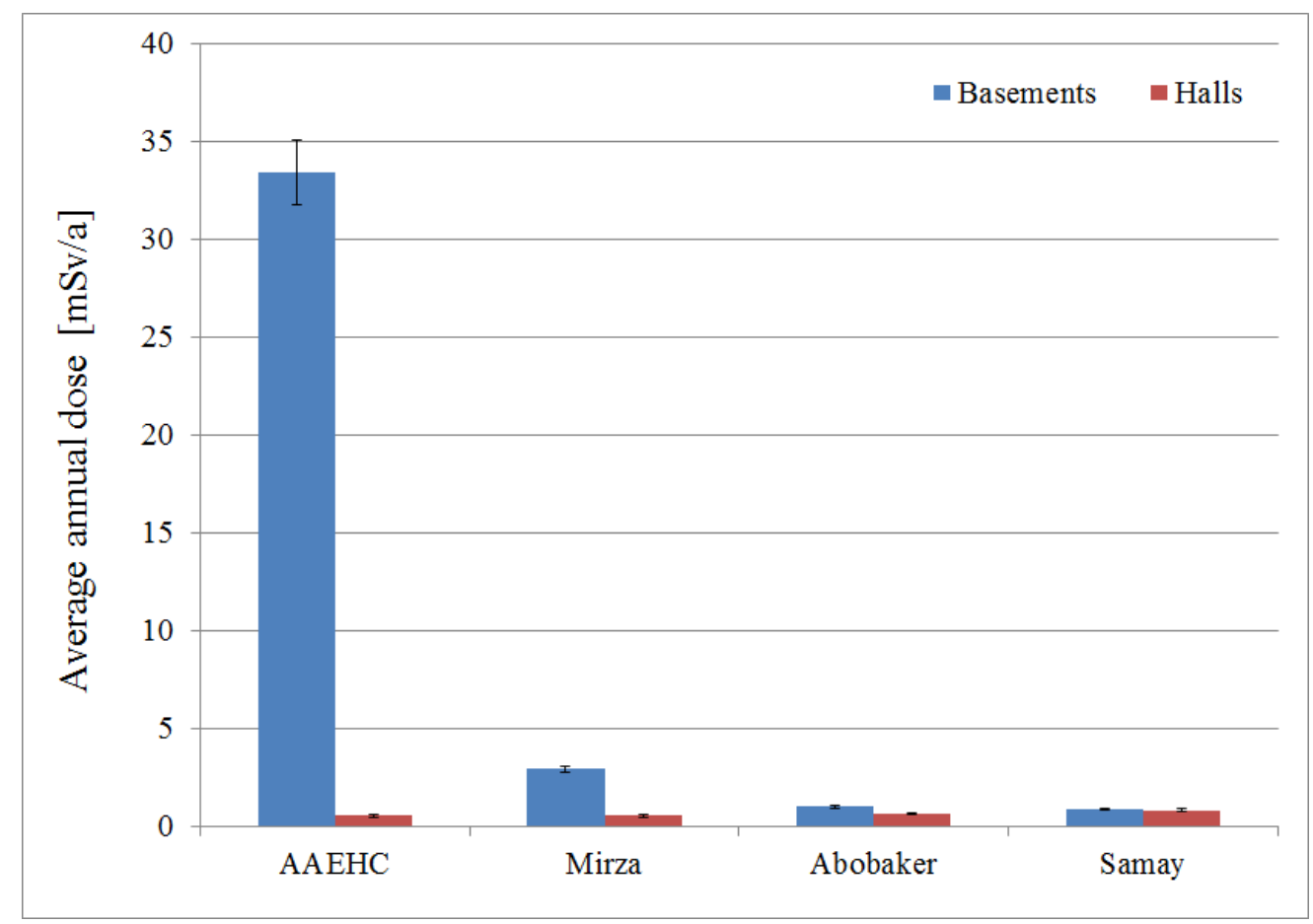

Fig. 4.8: Comparison of estimated annual dose between basements and living rooms/hall.

The figure clearly shows a difference in concentration between living rooms/halls and basements especially in the case of AAEHC hall and basement.

As one can also see from Fig.4.7, stay in the AAEHC basement leads to a higher annual effective dose (33.43 mSv/a) than the level proposed by ICRP, IAEA, and EURATOM. The reasons for this fact are existing ventilation conditions as well as construction materials used. Both basements are equipped with very poor ventilation systems. Additionally, due to working and weather conditions the doors and windows are not regularly opened for aeration, especially when ambient temperatures are very high or low. The building materials are mainly cement, ceramic and gypsum, which are considered well-known sources of radon. The adjacency of the basement to the ground also counts for the enhancement of radon concentration. The results of this study are well in line with the wellknown fact that ventilation and adjacency to the ground play a crucial role in enhancement of radon concentration. Furthermore, buildings made of concrete show somewhat higher radon concentrations than other buildings. Due to a lack of appropriate heating, 
ventilation and air exchange, the seasonal weather change is an intensifying factor concerning radon activity enhancement. This could be observed from an increase of radon activity during the cold season, when doors and windows were constantly kept closed. The only seasonal measurement which does not follow the temperature path is that in the AAEHC basement. The reason for that is mentioned in the interpretation of Table 4.9 above. The relative mean seasonal dependence for all locations in four seasons is shown in Fig.4.9.

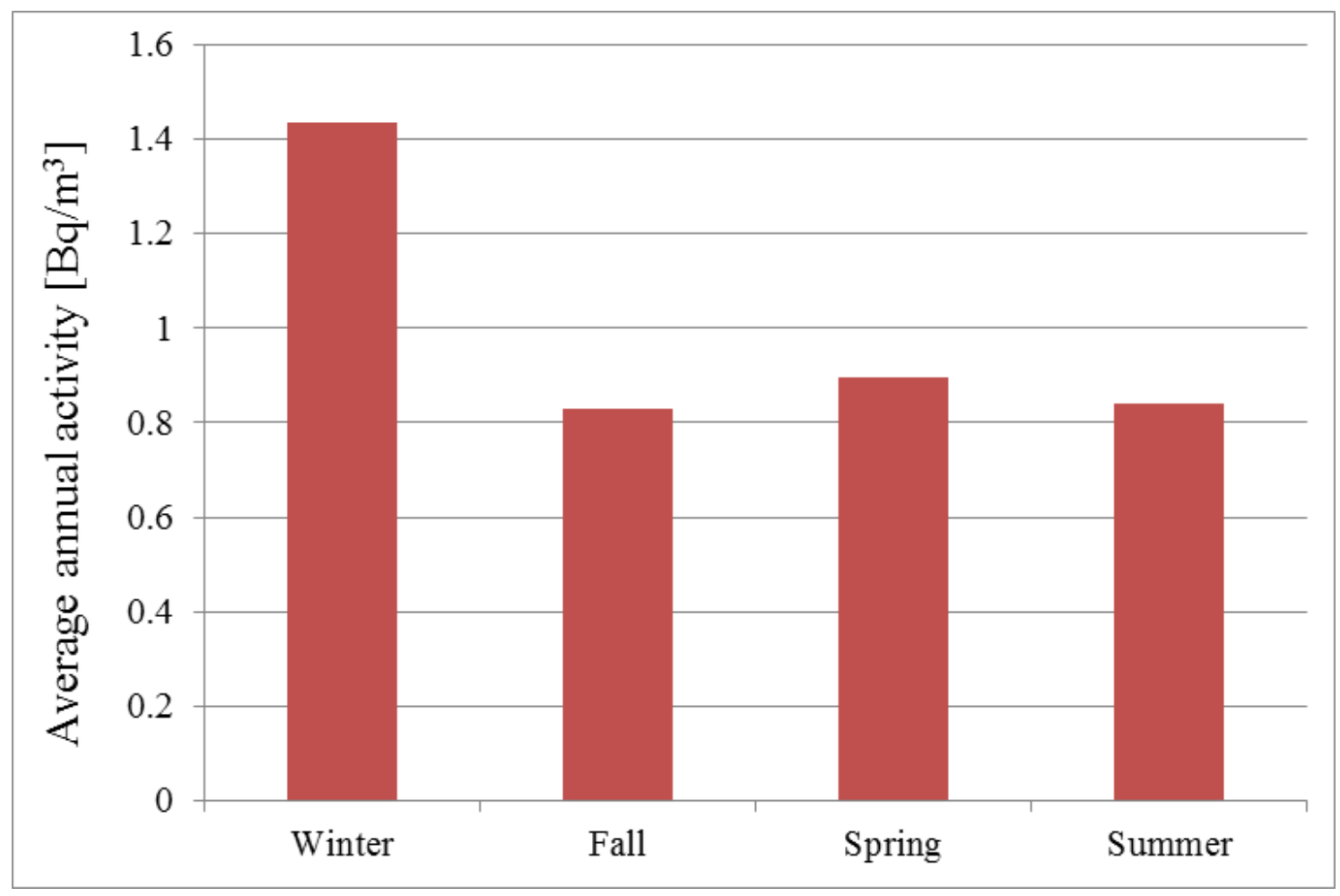

Fig. 4.9: Relative mean seasonal dependence for all locations in four seasons

As seen in Fig. 4.9 the seasonality plays an important role in the enhancement of the radon concentration.

In an overall look at mean annual concentration of each measurement site, one can conclude that the basement with its poor air exchange possibility has higher concentration. The mean annual activity for each site is shown in figure 4.10 . 


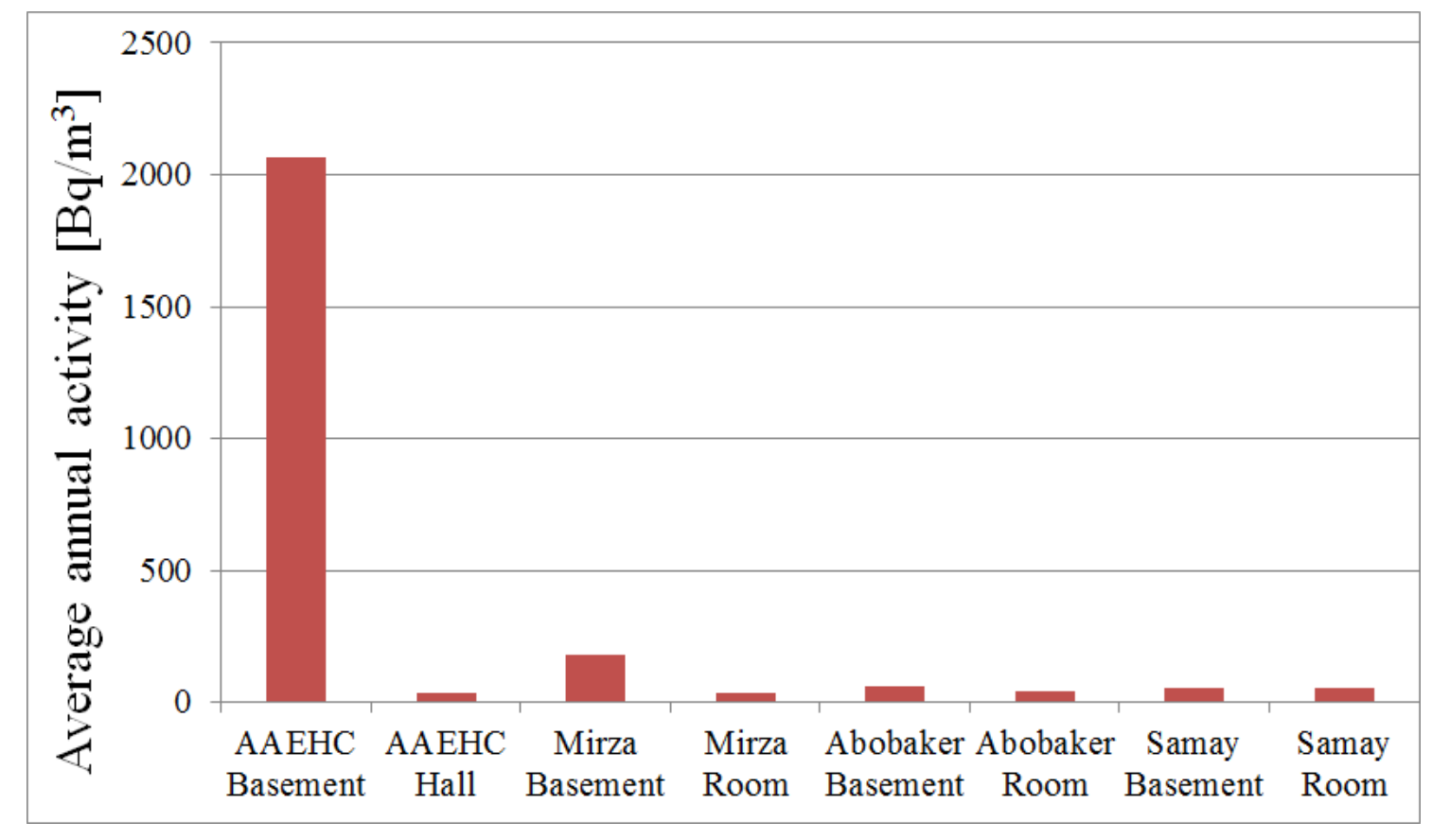

Fig. 4.10: Mean annual average activity concentration for each site

As seen in the figure, the AAEHC and Mirza basements show higher radon concentration than the other locations. This may be either due to the fact that the ventilation is bad or that the concrete buildings have a higher potential to enhance radon concentration. 


\section{Chapter}

\section{Conclusions and final remarks}

The environmental radioactivity monitoring program which was initiated by the joint AGS and Russian experts team in the 1980s provided little to no information on the activity concentration of different elements as well as the mineralogical structure of the rocks in the area. On the other hand, claims about the presence of artificial radioactive contaminates in the area as reported by Dr. Durakovic (Durakovic, 2003) raising questions and concerns. However, results have not been addressed in a scientific peer reviewed publication. Furthermore, lack of information on the radon activity level in caves and other residential areas also added to unanswered questions regarding the environmental radioactivity studies in Afghanistan. In general, these questions and lack of scientific studies concerning environmental radioactivity level and possible contamination initiated the idea of the study performed within this $\mathrm{PhD}$. In this study, ultimate attention was given to follow the map provided in the study of the 1980s during the rock and soil sample collection, while water and radon sampling locations were chosen based on diversity to represent the average of all life style in the area.

The three major phases of the study classified based on the type of samples can be concluded as follow.

\subsection{Rock and soil}

As mentioned before, the gamma lines selected for the evaluation in these measurements were chosen based on energy line abundance of the concerning isotope as well as interference energy lines from the other isotopes. If the system is undisturbed and old enough, all the daughter nuclides of the three decay chains should be in a secular equilibrium. Thus, if the system is not in secular equilibrium the short lived nuclides which can grow in up to six half-lives can be used as indicators of the concentration of the mother nuclei. For gamma spectroscopy in this study, the following lines were chosen to evaluate the activity concentration of the mother nuclides.

To determine ${ }^{238} \mathrm{U}$, the $63.28 \mathrm{keV}$ energy line of ${ }^{234} \mathrm{Th}$ and the 766.37 and $1001.03 \mathrm{keV}$ energy lines of ${ }^{234 \mathrm{~m}} \mathrm{~Pa}$ can be used. But as mentioned above, for a better accuracy energies 
less than $100 \mathrm{keV}$ were neglected in the evaluation process. Thus, only the $766 \mathrm{keV}$ and $1001 \mathrm{keV}$ lines of ${ }^{234 \mathrm{~m}} \mathrm{~Pa}$ were used. The $766 \mathrm{keV}$ line has a probability of $0.32 \%$ and is possibly disturbed by the $768 \mathrm{keV}{ }^{214} \mathrm{Bi}$ line. Therefore, the $1001 \mathrm{keV}$ line of ${ }^{234 \mathrm{~m}} \mathrm{~Pa}$ with a $0.84 \%$ probability was chosen as preferred line for ${ }^{238} \mathrm{U}$ determination. As a progeny of the uranium series, the $186.2 \mathrm{keV}$ direct energy line of ${ }^{226} \mathrm{Ra}$ with a probability of 3.64 $\%$ is highly disturbed by the $186.3 \mathrm{keV}$ line of ${ }^{221} \mathrm{Rn}$ with a probability of $21.6 \%, 185.72$ $\mathrm{keV}$ of ${ }^{235} \mathrm{U}$ and possibly by the $188 \mathrm{keV}$ line of ${ }^{225} \mathrm{Ac}$ with a probability of $0.45 \%$. Therefore, to determine the activity concentration of ${ }^{226} \mathrm{Ra}$, the 295 and $352 \mathrm{keV}$ energy lines of the ${ }^{214} \mathrm{~Pb}$ and $1120 \mathrm{keV}$ and1764 keV lines of ${ }^{214} \mathrm{Bi}$ were used. ${ }^{232} \mathrm{Th}$ was determined using its two progenies ${ }^{228} \mathrm{Ra}$ and ${ }^{228} \mathrm{Th}$. The ${ }^{228} \mathrm{Ac} 911 \mathrm{keV}$ and $967 \mathrm{keV}$ lines $\left(0.25 \%\right.$ and $0.15 \%$ probability, resp.) were selected to determine ${ }^{228} \mathrm{Ra}$, the $238 \mathrm{keV}$ line of ${ }^{212} \mathrm{~Pb}$ and $583 \mathrm{keV}$ and $860 \mathrm{keV}^{208} \mathrm{Tl}$ energy lines with probabilities of $0.43 \%, 0.3 \%$ and $0.044 \%$, respectively, were chosen to determine the ${ }^{238} \mathrm{Th}$ concentration. Al though the ${ }^{228} \mathrm{Ac}$ has gamma lines at 209, 338 and $409 \mathrm{keV}$, but the $209 \mathrm{keV}$ had a lower probability, $338 \mathrm{keV}$ had the possibility to be highly disturbed by the ${ }^{223} \mathrm{Ra}$ of the ${ }^{235} \mathrm{U}$ series and the $409 \mathrm{keV}$ had a factor of 10 lower probability. The ${ }^{235} \mathrm{U}$ activity concentration was determined via its direct gamma lines at $163 \mathrm{keV}$ and $205 \mathrm{keV}$ as well as on the basis of its progeny ${ }^{227} \mathrm{Ac}$, which was determined via $402 \mathrm{keV}{ }^{219} \mathrm{Rn}$ and $405 \mathrm{keV}{ }^{211} \mathrm{~Pb}$ energy lines. The 143.7 and $185.72 \mathrm{keV}$ lines of ${ }^{235} \mathrm{U}$ were neglected due to the probability of interference from $144.2 \mathrm{keV}$ and $144.7 \mathrm{keV}$ of ${ }^{223} \mathrm{Ra}$ and ${ }^{221} \mathrm{Rn}$, respectively, and 186.3 $\mathrm{keV}$ of ${ }^{221} \mathrm{Rn}$. Finally, the single $1460 \mathrm{keV}$ energy line was picked to determine the activity concentration of ${ }^{40} \mathrm{~K}$.

Different elements do not directly undergo gamma emission. As mentioned above, they may undergo alpha and beta emissions, which may or may not be followed by a gamma decay. The alpha and beta particles emitted by a source have the possibility to be scattered via elastic and inelastic collisions with the nuclides of the source material. This can cause a decrease in the energy of the particle or in case the material is thick enough it can cause an absorption as well. These two phenomena are called self-scattering and self-absorption, respectively. Self-absorption and self-scattering play a significant role in alpha spectroscopy in comparison to gamma spectroscopy, because in alpha spectroscopy each single particle emitted by the source is recorded. Therefore, losing an alpha particle as a result of self-absorption or scattering will give unrealistic numbers of alphas (Ademola 
et al., 2014). Absorption and backscatter keep increasing with an increase in thickness of the scattering material until it reaches the saturation level, and finally remain constant beyond that. The saturation level can be reached within a thickness of about one-third of the maximum range of the scattered particles (Faires \& Boswell, 1981).

Looking at chronological and geological information about the sampling area, all different techniques used for the measurements and analyses indicate that these soil and rock samples have an enhanced radioactivity level as compared to that of normal rocks found in their vicinity. Gamma and alpha spectroscopy results show that the thorium activity concentration is higher than that of uranium, which is verified by PXRD and EDX measurements. PXRD also reveals that the presence of considerable amounts of thorium is due to the mineralogical structure of the samples containing cheralite.

The uranium in our samples were only detected by alpha spectroscopy not gamma spectroscopy, this can be due to the fact that on one hand ${ }^{234 \mathrm{~m}} \mathrm{~Pa}$ has a low emission probability at $1001 \mathrm{keV}$, and on the other hand the detector efficiencies in this energy region are relatively low (Kaste et al., 2006). Furthermore, alpha spectroscopy records the event of each incident particle coming to the detector. Having said that, the gamma spectroscopy is not the optimal technique for quantifying the uranium isotope ratios (and maybe even uranium concentration) in this case. In samples like these, the alpha spectrometric measurements are more trustworthy but nevertheless keeping in mind the special geological and mineralogical structure, higher radon concentration in caves and basements and the enhanced radioactivity in the area might suggest limited use for human housing (Wolfart, 1980; Tanha et al., 2017).

\subsection{Water}

Concentrations of elements analysed for samples collected in the first sampling phase of the study were all below the recommended guideline values, except for sample number 8. Thus, it can be concluded that the drinking water provided by AUWSSC in Kabul is in good condition concerning its level of hazardous toxic elements. The sample number 8 collected in a village from a well with agriculture and livestock farming, including use of farmyard manure and chemical fertilizers in the vicinity showed enhanced concentration of uranium. Enhanced uranium concentration in the well water may be related to the 
presence of nitrate deriving from fertilizers, which causes oxidation of uranium, and thus mobilization and leaching to the ground water (Nolan et al., 2015).

Samples collected in the second phase showed a low concentration of uranium and lead, whereas measurement of thorium resulted in relatively high concentrations in samples number 1 and 20. However, due to the high uncertainty of the measurements, it is impossible to decide, whether the concentration is really higher than would be expected.

In the third phase, all elements analysed were below the recommended guideline values, thus the water quality meets the requirements concerning $\mathrm{U}, \mathrm{Th}, \mathrm{Ra}$, and $\mathrm{Pb}$ concentrations.

The highest uranium concentration in the Faryab province of northern Afghanistan recorded by Banks et al. (2014) was 62 ppb from dug wells in Qurgan and Andkhoi. Groundwater uranium concentrations were found to increase towards the north of the province, which may indicate that uranium anionic complexes are susceptible to the same evapoconcentration processes as many other soluble elements. Alternatively, the high concentrations of uranium in saline ground waters may be mobilised by complexation with salinity-related species, such as sulphate. A much stronger correlation was found with sulphate compared to chloride. Uranium minerals within igneous or metamorphic rocks (e.g. apatite, zircon), uranium within dark organic sedimentary marine mud rocks and shales and inorganic fertilisers, especially those derived from apatite, are suggested as ultimate sources of uranium (Banks et al., 2014).

The solubility of radium, thorium and uranium in groundwater was calculated with the speciation modeling software PHREEQC (David. L \& Parkhurst, 1999) and the PSI/Nagra Chemical Thermodynamic Database (Thoenen et al., 2014) using recommended data only. The employed groundwater composition represents an average Kabul groundwater based on the inventory established by Broshears et al (Broshears et al., 2005). The solubilities of radium, uranium and thorium were calculated as a function of $\mathrm{pH}$ for the described water in equilibrium with $\mathrm{ThO}_{2}$ (am,hyd,fr), $\mathrm{ThO}_{2}$ (am,hyd,ag), $\mathrm{ThF}_{4}$ (cr,hyd), $\mathrm{Na}_{6} \mathrm{Th}\left(\mathrm{CO}_{3}\right)_{5} \cdot 12 \mathrm{H}_{2} \mathrm{O}(\mathrm{cr}), \mathrm{UF}_{4} \cdot 2.5 \mathrm{H}_{2} \mathrm{O}(\mathrm{cr}), \mathrm{U}(\mathrm{OH})_{2} \mathrm{SO}_{4}(\mathrm{cr}), \mathrm{UO}_{2}$ (am,hyd), Rutherfordine, Chernikovite, $\left(\mathrm{UO}_{2}\right)_{3}\left(\mathrm{PO}_{4}\right)_{2} \cdot 4 \mathrm{H}_{2} \mathrm{O}(\mathrm{cr})$, Metaschoepite, Becquerelite, Compreignacite, $\mathrm{RaCO}_{3}(\mathrm{cr}), \mathrm{RaSO}_{4}$ (cr). 
Table 5.1: Average composition of Kabul groundwater based on the inventory established by Kabul groundwater (Broshears et al., 2005) and used for geochemical calculations.

\begin{tabular}{lr}
\hline Analyte & $\mathrm{c}(\mathrm{mg} / \mathrm{L})$ \\
\hline $\mathrm{O}_{2}$ & 7.3 \\
\hline $\mathrm{N}$ & 7.164 \\
\hline $\mathrm{Ca}$ & 80.3493519 \\
\hline $\mathrm{Mg}$ & 67.2009259 \\
\hline $\mathrm{Na}$ & 119.213519 \\
\hline $\mathrm{K}$ & 6.27064815 \\
\hline $\mathrm{HCO}_{3}{ }^{-}$ & 172.900174 \\
\hline $\mathrm{C}$ & 68.0479256 \\
\hline $\mathrm{Cl}$ & 158.872789 \\
\hline $\mathrm{S}$ & 57.266859 \\
\hline $\mathrm{F}$ & 0.34278846 \\
\hline $\mathrm{Br}$ & 0.43355435 \\
\hline $\mathrm{Si}$ & 24.9166667 \\
\hline $\mathrm{Al}$ & 0.027292 \\
\hline $\mathrm{As}$ & 0.00183868 \\
\hline $\mathrm{Ba}$ & 0.06572685 \\
\hline $\mathrm{B}$ & 0.7161215 \\
\hline $\mathrm{Fe}$ & 0.03978462 \\
\hline $\mathrm{Li}$ & 0.09108056 \\
\hline $\mathrm{Mn}$ & 0.02718889 \\
\hline $\mathrm{Mo}$ & 0.00336667 \\
\hline $\mathrm{Ni}$ & 0.0045271 \\
\hline $\mathrm{Se}$ & 0.00382371 \\
\hline $\mathrm{U}$ & 0.00845102 \\
\hline
\end{tabular}

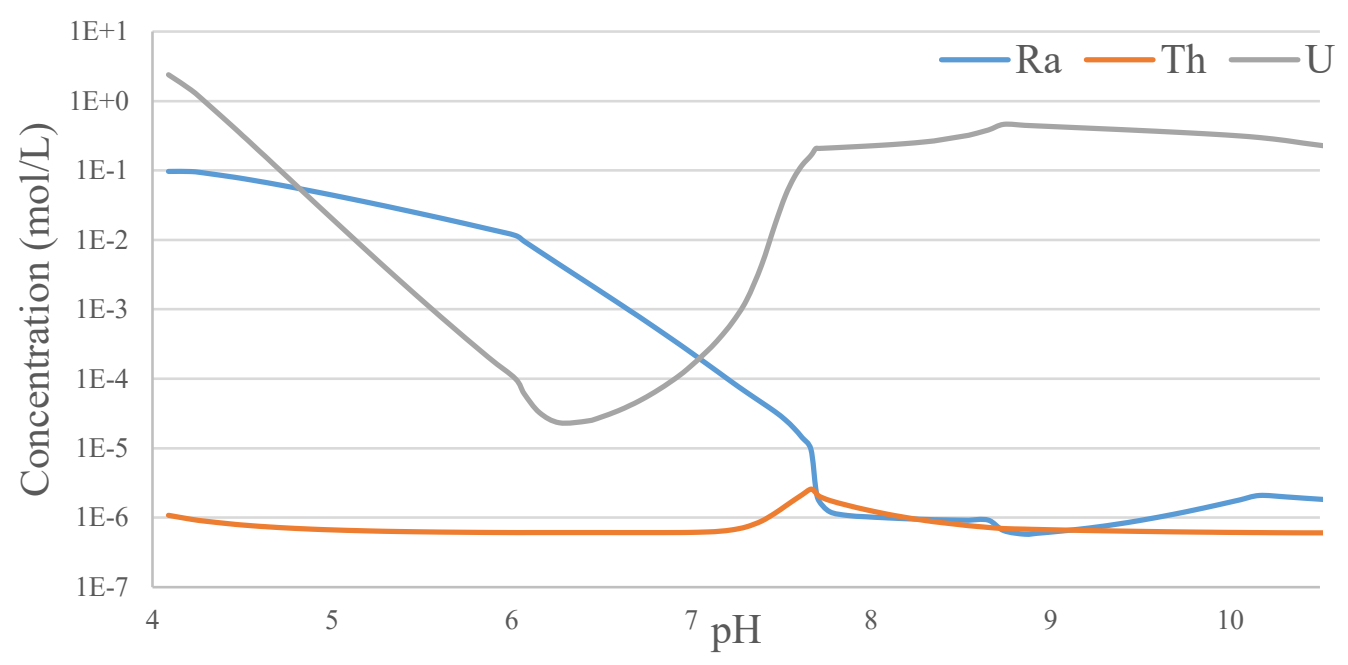

Fig.5.1: Solubility of radium, thorium and uranium in Kabul groundwater 
The widespread distribution of ${ }^{238} \mathrm{U}$, and thus the widespread distribution of its daughter products such as ${ }^{226} \mathrm{Ra}$, as compared to thorium, is caused by its relatively high solubility in low $\mathrm{pH}$ or acidic phase. Thus, the progeny of ${ }^{238} \mathrm{U},{ }^{226} \mathrm{Ra}$, is commonly found in ground water. The geochemical properties of ${ }^{226} \mathrm{Ra}$ differ from those of ${ }^{238} \mathrm{U}$, however, the cooccurrence is not common (Szabó et al., 1992), because the degree and chemical conditions of mobilization of the parent ${ }^{238} \mathrm{U}$ and the product ${ }^{226} \mathrm{Ra}$ are different (Focazio et al., 1998-2001).I $t$ might also be possible that the radium is absorbed during migration to the sampling site.

\subsection{Radon}

To the best of our knowledge, this is the first study providing systematic data on indoor radon concentrations for Afghanistan. We note, however, that the number of measurement locations was too small for a representative radiological country-wide evaluation, due to the difficult political, economical and societal situation in this country. Nevertheless, a number of conclusions can be drawn.

Besides a high radon concentration, the occupancy time is an important parameter that governs high effective doses. As the residents of all of the measurement sites including offices and caves used these spaces on average for about 12 hours including weekends, they are all considered as normal residents or members of the public with a slight workload. Therefore, any dose exceeding the level proposed by IAEA for members of the public will need further action for minimizing the radon dose (IAEA, 2014a).

Having said that, it is recommended:

- In order to give radon more chance to escape specially in cold seasons, equip new and old buildings with proper warming systems.

- Open and close doors and windows as often as possible, to increase natural ventilation and minimize radon concentrations (Cavallo et al., 1992).

- For places like AAEHC basement, this recommendation needs to be fulfilled as quickly as possible.

- Further radon measurements in Afghanistan at different climatic conditions and various building materials are recommended. 
- Due to its building material and style, priority should be given to old hospitals, offices, kindergartens, military barracks, cinemas, halls, schools and university buildings which are built in Soviet times with relatively enhanced use of concrete and their ventilation systems being semi or fully out of order.

\subsection{Recommendations for future work}

As discussed in the result section, there exists little to no information on environmental radioactivity in Afghanistan. This includes detailed study of radionuclides concentration in soil, water and rocks as well as concentration of radon in air. Currently there exists no information in a reasonable scale on concentration of radon in old and new buildings as well as old and newly constructed caves used as living spaces in different parts of Afghanistan. The mining section in Afghanistan is suffering from the lack of the same information, there is no single research paper, article, external or internal report on measurements of the concentration of radon and other hazardous radionuclides of the trace level in mines. Furthermore, there is a lack of information on contamination from orphan sources once used in Afghanistan for medical and research purposes.

Covering all the above issues, requires broad and multi-dimensional studies but, one can summarise and prioritise the further study areas as follows:

- Radon measurements in coal mines which are very deep having bad ventilation should be given top priority.

- A broad study should be carried out for measuring radon concentrations in different enclosed spaces used for living and working.

- The qualitative and quantitative assessment of radionuclides in drinking waters all over Afghanistan needs to be carried out.

- The qualitative and quantitative analysis of soil samples from areas where probable contamination is expected due to discharge, loss and dispersion of the radionuclides once used for medical and research purposes.

- The study of granite rocks in areas which are used as residence or areas with ongoing mining activities. 


\section{References}

Ademola, A. K., Bello, A. K., \& Adejumobi, A. C. (2014). Determination of natural radioactivity and hazard in soil samples in and around gold mining area in Itagunmodi, south-western, Nigeria. Journal of Radiation Research and Applied Sciences, 7, 249 255.

AGS and AAEHC (2010-2012). Radiometric studies and illegal housing in Kabul and suburbs: Afghanistan Geological Survey and Afghan Atomic Energy High Comission collaboration reports. Internal collaboration report for internal use only. Kabul.

Ahmed, S. N. (2015). Physics and engineering of radiation detection. (Second edition). Waltham: Elsevier.

Andritzky, G. (1971). Das Kristallin im Gebiet Panjao-Kabul-Jalalabad (Zentral- und Ost- Afghanistan), 96.

Attix, F. H. (1986). Introduction to Radiological Physics and Radiation Dosimetry. Weinheim, Germany: Wiley-VCH Verlag GmbH.

Attrep, M., \& Kahn, B. (2007). Radioanalytical Chemistry Experiments: Springer New York.

Atwood, D. A. (2010). Radionuclides in the environment. EIC Books. Oxford: Wiley.

Banks et al. (2014). Hydrogeological Atlas of Faryab Province: Northern afghanistan. Kabul: Ministry of Rural Rehabilitation \& Development.

Bateman, H. (1843). Solution of a system of differential equations occurring in the theory of radioactive transformations: Proceedings of the Cambridge Philosophical Society, Mathematical and physical sciences., 15.

Beer, J., McCracken, K., \& Steiger, R. von (2012). Goals. In J. Beer, K. McCracken, \& R. von Steiger (Eds.), Cosmogenic Radionuclides (pp. 7-9). Berlin, Heidelberg: Springer Berlin Heidelberg.

BFS (2015). Umweltradioaktivität und Strahlenbelastung: Jahresbericht 2013. http://doris.bfs.de/jspui/handle/urn:nbn:de:0221-2015072112949.

BIPM (2008). Evaluation of measurement data - Guide to the expression of uncertainty in measurement of uncertainty in measurement. (JCGM 100). Paris, France: BIPM.

Birkhan, J. H. (2009). Gamma Spektrometrie an Bodenproben von als Grünland genutzten Auenflächen der Zwickauer und Vereinigten Mulde. Diplom. Hannover, Germany. 
Birkholz, M., Fewster, P. F., \& Genzel, C. (Eds.) (2006). Thin film analysis by X-ray scattering. Weinheim: Wiley-VCH.

Bister, S., Koenn, F., Bunka, M., Birkhan, J., Lüllau, T., Riebe, B., \& Michel, R. (2010). Uranium in water of the Mulde River. Journal of Radioanalytical and Nuclear Chemistry, 286, 367-372.

BMUB (2006). Messanleitungen für die Überwachung der Radioaktivität in der Umwelt und zur Erfassung radioaktiver Emissionen aus kerntechnischen Anlagen. Berlin: BMUB.

Bottrell, S. H. (1993). Redistribution of uranium by physical processes during weathering and implications for radon production. Environmental geochemistry and health, 15, $21-25$.

Boyle, R. W. (1982). Geochemical prospecting for thorium and uranium deposits. Amsterdam, New York: Elsevier Scientific Pub. Co; New York Distributors for the U.S. and Canada.

Brennan, R., Dulude, J., \& Thomas, R. (2015). Approaches to Maximize Performance and Reduce the Frequency of Routine Maintenance in ICP-MS, 30, 12-25.

Broshears, R. E., Akbari, M. A., Chornack, M. P., Mueller, D. K., \& Ruddy, B. C. (2005). Inventory of Ground-Water Resources in the Kabul Basin, Afghanistan. USGS Afghanistan Project Product No. 001. Virginia, USA.

Bruker (2017). XRD Analyzer D2 PHASER.

Bundesamt für Strahlenschutz (2014). Umweltradioaktivität und Strahlenbelastung: Jahresbericht. München.

Burton et al. (2002). Stormwater effects handbook: A toolbox for watershed managers, scientists and engineers / G. Allen Burton, Jr. and Robert E. Pitt. Boca Raton, Fla.: Lewis Publishers.

Cavallo, A., Gadsby, K., \& Reddy, T. A. (1992). Use of natural basement ventilation to control radon in single family dwellings. Atmospheric Environment. Part A. General Topics, 26, 2251-2256.

Chernobyl Forum (2005). Chernobyl's legacy: health, environmental and socio-economic impacts and recommendations to the governments of Belarus, the Russian Federation and Ukraine. Vienna.

Chin, S. K. (2012). Minerals Yearbook: Area Reports: International Review: 2012 Asia and the Pacific. The Mineral Industry of Afghanistan, 3. 
Climate data. Climate: Kabul - Temperature, Climate graph, Climate table - ClimateData. http://en.climate-data.org/location/120/.

Croudace, I. W., \& Rothwell, R. G. (2015). Micro-XRF studies of sediment cores: Applications of a non-destructive tool for the environmental sciences / Ian W. Croudace, R. Guy Rothwell, editors. Developments in paleoenvironmental research, 1571-5299, volume 17. Dordrecht: Springer.

CTBTO (2017). Nuclear testing: World overview. Vienna.

David. L, \& Parkhurst, C. (1999). USER'S GUIDE TO PHREEQC (VERSION 2) A COMPUTER PROGRAM FOR SPECIATION, BATCH-REACTION, ONEDIMENSIONAL TRANSPORT, AND INVERSE GEOCHEMICAL CALCULATIONS. Water-Resources Investigations Report 99-4259. ftp://brrftp.cr.usgs.gov/pub/dlpark/geochem/pc/phreeqc/manual.pdf.

Dinh Chau, N., Dulinski, M., Jodlowski, P., Nowak, J., Rozanski, K., Sleziak, M., \& Wachniew, P. (2011). Natural radioactivity in groundwater--a review. Isotopes in Environmental and Health Studies, 47, 415-437.

Dunai, T. J. (2010). Cosmogenic nuclides: Principles, concepts and applications in the earth surface sciences / Tibor J. Dunai. Cambridge: Cambridge University Press.

Dupree, L. (1970). Afghanistan. Oxford Pakistan paperbacks. Karachi, Oxford: Oxford University Press.

Durakovic, A. (2003). Undiagnosed illnesses and radioactive warfare. Croatian medical journal, 44, 520-532.

Eckert \& Ziegler Nuclitec Gmbh. RADIOACTIVE SOLUTIONS AND GASES. Berlin: Eckert \& Ziegler Nuclitec Gmbh.

Eichrom Technologies. Inc (2001). Uranium and Thorium in Water. Analytical Procedures. Lisle, USA.

Eichrom Technologies. Inc (2013). Uranium and Thorium in Water. Analytical Procedures. Lisle, USA.

Eisenbud, M., \& Gesell, T. F. (1997). Environmental radioactivity: From natural, industrial, and military sources / Merril Eisenbud, Thomas Gesell. (4th ed.). San Diego, Calif., London: Academic Press.

Etemadi, H. Y. (2016). SFD Report - Kabul, Afghanistan: SFD Promotion Initiative. Kabul. 
Faires, R. A., \& Boswell, G. G. J. (1981). Radioisotope laboratory techniques. (4th ed. / by R.A. Faires, G.G.J. Boswell). London: Butterworths.

Faryad, S. W., Collett, S., Finger, F., Sergeev, S. A., Čopjaková, R., \& Siman, P. (2016). The Kabul Block (Afghanistan), a segment of the Columbia Supercontinent, with a Neoproterozoic metamorphic overprint. Gondwana Research, 34, 221-240.

Fawell, J. (2003). Contaminants in drinking water. British Medical Bulletin, 68, 199-208.

Finkelstein et al. (1996). Radium in drinking water and risk of bone cancer in Ontario youths: A second study and combined analysis. Occupational and environmental medicine, 53, 305-311.

Florian, K. (2009). a Alpha spektrometrische Untersuchungen von Wasserproben aus der Zwickauer Mulde. Diplom. Hannover, Germany.

Focazio et al. (1998-2001). Occurrence of Selected Radionuclides in Ground Water Used for Drinking Water in the United States: A Targeted Reconnaissance Survey, 1998.

Ghosh, D., Deb, A., Bera, S., Sengupta, R., \& Patra, K. K. (2008). Measurement of natural radioactivity in chemical fertilizer and agricultural soil: Evidence of high alpha activity. Environmental geochemistry and health, 30, 79-86.

Gilmore, G. R. (2008). Practical Gamma-Ray Spectrometry. Chichester, UK: John Wiley $\&$ Sons, Ltd.

Global Sino (2017). EDX excitation principle. http://www.globalsino.com/micro/1/images/micro9999.jpg.

Goudsouzian, T. (2011). Something in the air in Kabul: Air pollution in Afghanistan is deteriorating, however efforts are underway to help clear the skies. Aljazeera English, 2011.

http://www.aljazeera.com/indepth/features/2011/03/201131514261904290.html.

Grau, L. W., \& Jalali, A. A. (2001). The campaign for the caves: The battles for Zhawar in the Soviet-Afghan war. The Journal of Slavic Military Studies, 14, 69-92.

Gruber, E., Salama, E., \& Rühm, W. (2011). Real-time measurement of individual occupational radon exposures in tombs of the Valley of the Kings, Egypt. Radiation protection dosimetry, 144, 620-626.

Grupen, C. (2010). Introduction to Radiation Protection: Practical Knowledge for Handling Radioactive Sources. Graduate Texts in Physics. Berlin, Heidelberg: SpringerVerlag Berlin Heidelberg. 
Grupen, C., \& Rodgers, M. (2016). Radioactivity and Radiation: What They Are, What They Do, and How to Harness Them. Cham: Springer.

Grupen, C., \& Shwartz, B. (Eds.) (2008). Particle Detectors. Cambridge: Cambridge University Press.

Gupta, D. K., \& Walther, C. (Eds.) (2017). Impact of Cesium on Plants and the Environment. Cham, s.l.: Springer International Publishing.

Hathcock, J. (2012). Nutritional Toxicology, v. 1: Elsevier Science.

Hayat, E., \& Baba, A. (2017). Quality of groundwater resources in Afghanistan. Environmental monitoring and assessment, 189, 318.

Higuchi, T., \& Barnes, G. (1995). Bamiyan: Buddhist cave temples in Afghanistan. World Archaeology, 27, 282-302.

Hölzer, A. (2013). Simultane Quantifizierung von Iodid und Iodat in Flüssig- und Bodenproben mittels IC-ICP-OES. Master thesis. Hannover, Germany.

Hu, Q.-H., Weng, J.-Q., \& Wang, J.-S. (2010). Sources of anthropogenic radionuclides in the environment: A review. Journal of environmental radioactivity, 101, 426-437.

Hunter, P. (2008). A toxic brew we cannot live without. Micronutrients give insights into the interplay between geochemistry and evolutionary biology. EMBO reports, 9, 1518.

IAEA (2002). Natural and Induced Radioactivity in Food. http://wwwpub.iaea.org/MTCD/Publications/PDF/te_1287_prn.pdf.

IAEA (2014a). Protection of the public against exposure indoors due to radon and other natural ources of radiation: Specific safety guide / jointly sponsored by The International Atomic Energy Agency and the World Health Organization. IAEA safety standard series, 1020-525X, no. SSG-32.

IAEA (2014b). Radiation protection and safety of radiation sources: International basic safety standards / jointly sponsored by: European Commission [and seven others]. IAEA safety standards series, 1020-525X, no. GSR part 3. Vienna.

IAEA-TECDOC (2011). Viability of sharing facilities for the disposal of spent fuel and nuclear waste: An assessment of recent proposals. IAEA-TECDOC, 1658. Vienna: International Atomic Energy Agency.

ICRP (1994a). Human respiratory tract model for radiological protection: A report of a task group of the International Commission on Radiological Protection, adopted by 
the Commission in September 1993. Oxford: published for the International Commission on Radiological Protection [by] Pergamon.

ICRP (1994b). Protection against radon-222 at home and at work. Annals- ICRP, vol 23 no 2.

ICRP (2007). The 2007 recommendations of the International Commission on Radiological Protection. Annals of the ICRP 103, 0146-6453, v. 37, no. 2-4. Oxford: Published for the International Commission on Radiological Protection by Elsevier.

Inorganic Ventures (2017). Inorganic standards and custom reference materials. https://www.inorganicventures.com/periodic-table.

International Atomic Energy Agency (1989). Uranium deposits in magmatic and metamorphic rocks: Proceedings of a Technical Committee Meeting on Uranium Deposits in Magmatic and Metamorphic Rocks / organized by the International Atomic Energy Agency ... held in Salamanca, ... 1986. Panel proceedings series. Vienna: International Atomic Energy Agency.

Irlinger, J. (2014). Development of an electronic monitor for the determination of individual radon and thoron exposure. Doctoral thersis. Munich, Germany.

Irlinger, J., Wielunski, M., \& Rühm, W. (2014). Thoron detection with an active Radon exposure meter--first results. The Review of scientific instruments, 85, 22106.

ISO (2012). Measurement of radioactivity in the environment -- Air: radon-222 -- Part 5: Continuous measurement method of the activity concentration. International Organization for Standardization.

Jeff Crisp, H. R. (2011). The urbanisation of displaced people: The conflict-driven urbanisation of Kabul, No.5.

Kamal, A. (Ed.) (2014). Particle Physics. Graduate Texts in Physics. Berlin, Heidelberg: Springer Berlin Heidelberg.

Karinda, F. L. (2009). Verbesserung und Einsatz von elektronischen Echtzeit-Exposimetern zur Bestimmung individueller Radonexpositionen. Doctoral thesis. München, Deutschland.

Karinda, F. L., Haider, B., \& R?hm, W. (2008). A new electronic personal exposure meter for radon gas. Radiation Measurements, 43, 1170-1174.

Karpas (2014). Analytical Chemistry of Uranium: Environmental, Forensic, Nuclear, and Toxicological Applications: Taylor \& Francis. 
Kaste, J. M., Bostick, B. C., \& Heimsath, A. M. (2006). Determining 234Th and 238U in rocks, soils, and sediments via the doublet gamma at $92.5 \mathrm{keV}$. The Analyst, 131, 757763.

Khushaim, M. (2015). Investigation of the Precipitation Behavior in Aluminum Based Alloys: Unpublished.

Knoll, G. F. (2010). Radiation detection and measurement. (4th ed.). Hoboken, N.J.: Wiley.

Kobets, S. A., \& Pshinko, G. N. (2014). Factors affecting forms of finding Th(IV) in aqueous solutions. Journal of Water Chemistry and Technology, 36, 51-55.

L'Annunziata, M. F. (2012). Handbook of radioactivity analysis. (3rd ed.). San Diego: Elsevier Science.

Lieser, K. H. (2008). Nuclear and Radiochemistry: Fundamentals and Applications. Hoboken: Wiley-VCH.

Lutz, G. (2001). Semiconductor Radiation Detectors: Device Physics: Springer Berlin Heidelberg.

Magill, J., \& Galy, J. (2005). Radioactivity, radionuclides, radiation. Berlin, London: Springer.

Matthew Forney (2011). Inside the Tora Bora Caves. Time magazine, December 2011. http://content.time.com/time/world/article/0,8599,188029,00.html.

Minteer, M., Winkler, P., Wyatt, B., Moreland, S., Johnson, J., \& Winters, T. (2007). Reliability of using $238 \mathrm{U} / 235 \mathrm{U}$ and $234 \mathrm{U} / 238 \mathrm{U}$ ratios from alpha spectrometry as qualitative indicators of enriched uranium contamination. Health physics, 92, 488495.

Mohmand et al. (1987). Reports on geophysical studies of Kabul suburbs (report in Dari). Kabul.

Murcott, S. (2012). Arsenic Contamination in the World: IWA Publishing.

Mussett, A. E., \& Khan, M. A. (2000). Looking into the earth: An introduction to geological geophysics / Alan E. Mussett, M. Aftab Khan ; illustrations by Sue Button. Cambridge: Cambridge University Press.

Nafaa Reguigui (2006). Gamma Ray Spectrometry Practical Information. http://www.cnstn.rnrt.tn/afra-ict/NAT/gamma/html/Gamma\%20Spec\%20V1.pdf.

Nazaroff, W. W., \& Nero, A. V. (1988). Radon and its decay products in indoor air. Environmental science and technology, 0194-0287. New York, Chichester: Wiley. 
Neck, V., Müller, R., Bouby, M., Altmaier, M., Rothe, J., Denecke, M. A., \& Kim, J. I. (2002). Solubility of amorphous Th(IV) hydroxide - application of LIBD to determine the solubility product and EXAFS for aqueous speciation, 90, 485-494.

Nelms, S. M. (2005). Inductively Coupled Plasma Mass Spectrometry Handbook. Oxford, UK: Blackwell Publishing Ltd.

Nolan et al. (2015). Natural Uranium Contamination in Major U.S. Aquifers Linked to Nitrate. Environmental Science \& Technology Letters, 2, 215-220.

Northern Arizona University (2017). Electron Microprobe Laboratory, SEM setup,. https://nau.edu/uploadedImages/Academic/CEFNS/Labs/Electron_Microprobe/_Media/SEM_schematic.jpg.

Nuccetelli, C., Rusconi, R., \& Forte, M. (2012). Radioactivity in drinking water: Regulations, monitoring results and radiation protection issues. Annali dell'Istituto Superiore di Sanità, 48, 362-373.

Ortec (2017). Why High-Purity Germanium (HPGe) Radiation Detection Technology is Superior to Other Detector Technologies for Isotope Identification. https:/www.ortec-online.com/-/media/ametekortec/technical\%20papers/homeland\%20security\%20applications $\% 20$ and $\% 20$ chemical\%20weapons $\% 20$ assay $\% 20$ pins/whyhighpuritygermaniumhpgeradiationdetectiontechnologysuperiorotherdetectortechnologiesisotopeidentification.pdf?la $=$ en.

Papadopoulos, A., Christofides, G., Koroneos, A., Stoulos, S., \& Papastefanou, C. (2013). Radioactive secular equilibrium in $238 \mathrm{U}$ and $232 \mathrm{Th}$ series in granitoids from Greece. Applied Radiation and Isotopes, 75, 95-104.

Perlman, I., Ghiorso, A., \& Seaborg, G. T. (1949). Relation Between Half-Life and Energy in Alpha-Decay. Physical Review, 75, 1096-1097.

Plum, L. M., Rink, L., \& Haase, H. (2010). The essential toxin: impact of zinc on human health. International journal of environmental research and public health, 7, 13421365 .

Podgoršak, E. B. (2014). Compendium to radiation physics for medical physicists: 300 problems and solutions. Heidelberg: Springer.

Podosek, F. A. (1978). Isotopic Structures in Solar System Materials. Annual Review of Astronomy and Astrophysics, 16, 293-334.

POL (2016). X-Ray Fluorescence Spectrometry. http://physicsopenlab.org/2016/02/24/diy-xrf-spectrometry/. 
Pöschl, M. (2007). Radionuclide concentrations in food and the environment. Food science and technology, [164]. Boca Raton, FL: CRC.

Prasad, M. (2008). Trace Elements as Contaminants and Nutrients: Consequences in Ecosystems and Human Health: Wiley.

Samet, J. M. (1992). Indoor radon and lung cancer. Estimating the risks. Western Journal of Medicine, 156, 25-29.

Schloerb et al. (1950). The measurement of total body water in the human subject by deuterium oxide dilution; with a consideration of the dynamics of deuterium distribution. The Journal of clinical investigation, 29, 1296-1310.

Schneider, S. H., Root, T. L., \& Mastrandrea, M. D. (2011). Encyclopedia of climate and weather. (2nd ed. / Stephen H. Schneider, Terry L. Root, editors in chief Michael D. Mastrandrea, associate editor in chief). Oxford: Oxford University Press.

Shklovskiĭ, B. I., \& Ėfros, A. L. (1984). Electronic properties of doped semiconductors. Springer series in solid-state sciences, 45. Berlin, New York: Springer-Verlag.

Siddeeg, S. E. M. B., \& Livens, F. (2013). Geochemistry of natural radionuclides in uranium-enriched river catchments. Great Britain: University of Manchester.

Skoog, D. A. (2016). Principles of instrumental analysis. (7th edition). San Francisco CA: Cengage Learning.

Szabó et al. (1992). Geologic and geochemical factors controlling uranium, radium-226, and radon-222 in ground water: Newark Basin, New Jersey, in Coalfields of New Mexico:. Geology and Resource.

Tanha, M., Vahlbruch, J.-W., Riebe, B., Irlinger, J., Rühm, W., Khalid, F. R., Storai, A., $\&$ Walther, C. (2017). Activity concentration and annul assesment of Radon dose in Afghanistan using an active radon exposure meter.

Tawussi, F. (2012). Gammaspektrometrische Untersuchung von Umweltproben Von der natürlichen Radioaktivität bis zum Fallout von Fukushima. Masterarbeit. Hannover, Germany.

Theodórsson, P. (1996). Measurement of weak radioactivity. Singapore, London: World Scientific.

Thoenen, T., Hummel, W., Berner, U., \& Curti, E. (2014). The PSI/Nagra Chemical Thermodynamic Database 12/07. Villigen PSI, Switzerland: Paul Scherrer Institut.

Thoennessen, M. (2016). The discovery of isotopes: A complete compilation. [Cham]: Springer. 
Thompson, L., Davidowski, L., Grosser, Z. A., \& Neubauer, K. (2008). A Comparison of ICP-OES and ICP-MS for the Determination of Metals in Food.

United Nations (2009). Water in a changing world. ([3rd ed.]). The United Nations world water development report, 3. London: Earthscan.

UNSCEAR (2000). Sources and effects of ionizing radiation: United Nations Scientific Committee on the Effects of Atomic Radiation UNSCEAR 2000 report to the General Assembly, with scientific annexes. New York: United Nations.

UNSCEAR (2008). Sources and effects of ionizing radiation: UNSCEAR 2008 report to the General Assembly, with scientific indexes. New York: United Nations.

UNSCEAR (2014). Sources, Effects and Risks of Ionizing Radiation, Unscear 2013 Report: Levels and Effects of Radiation Exposure Due to the Nuclear Accident After the 2011 Great East-japan Earthquake: United Nations Pubns.

Upp, D. L., Keyser, R. M., \& Twomey, T. R. (2005). New cooling methods for HPGE detectors and associated electronics. Journal of Radioanalytical and Nuclear Chemistry, 264, 121-126.

Virginia, C., Resources, C. E., Resources, B., Studies, D., \& Council, N. R. (2012). Uranium Mining in Virginia: Scientific, Technical, Environmental, Human Health and Safety, and Regulatory Aspects of Uranium Mining and Processing in Virginia: National Academies Press.

Vogt, H.-G., Schultz, H., \& Vahlbruch, J.-W. (2011). Grundzüge des praktischen Strahlenschutzes. (6., überarb. Aufl.). München [u.a.]: Hanser.

Washington, C. M., \& Leaver, D. T. (2016). Principles and practice of radiation therapy. (Fourth edition). St. Louis, Missouri: Elsevier Mosby.

Weiß, M. (2015). Fabrication, physical and chemical characterization of multifunctional inorganic nanoparticles for ultraviolet light filtration: Study on a-Fe2O3- and a$\mathrm{Fe} 2 \mathrm{O} 3 / \mathrm{CeO} 2$ composite materials. Master. Hannover, Germany.

Westmeier, J. B., \& Patzelt, W. P. ON THE PHOTOPEAK EFFICIENCY OF GERMANIUM GAMMA-RAY DETECTORS.

WHO (2002). INFORMATION SHEET: RADON AND HEALTH. Final report. (Final). Geneva.

WHO (2003). Zinc in Drinking-water: Background document for development of WHO Guidelines for Drinking-water Quality. Geneva. 
WHO (2010a). Aluminium in drinking-water: Background document for development of WHO Guidelines for Drinking-water Quality. Geneva.

WHO (2010b). PREVENTING DISEASE THROUGH HEALTHY ENVIRONMENTS: EXPOSURE TO ARSENIC: A MAJOR PUBLIC HEALTH CONCERN. Geneva.

WHO (2011a). Arsenic in Drinking-water: Background document for development of WHO Guidelines for Drinking-water Quality. Geneva.

WHO (2011b). Lead in Drinking-water: Background document for development of WHO Guidelines for Drinking-water Quality. Geneva.

WHO (2011c). Uranium in Drinking-water: Background document for development of WHO Guidelines for Drinking-water Quality. Geneva.

WNA (2016). Naturally-Occurring Radioactive Materials: Terrestrial NORM. Naturally-Occurring Radioactive Materials NORM.

Wolfart, W. (1980). Geologie Von Afghanistan: Gebruder Borntraeger Verlagsbuchhandlung, Science Publishers.

World Bank (2014). Indicators data: Arable land (\% of land area). Washington, United States.

World Bank (2015). Afghanistan - Kabul Municipal Development Program: Implementation Status Results Report Sequence 03. The World Bank.

Young, H. D., Freedman, R. A., Ford, A. L., \& Sears, F. W. (2016). Sears and Zemansky's university physics: With modern physics. (14th edition). Boston: Pearson.

Zapecza et al. (1986). Natural Radioactivity in Ground Water: A Review. Washington, USA: U.S. Geological Survey. 


\section{Annexes}

\section{Annex 1}

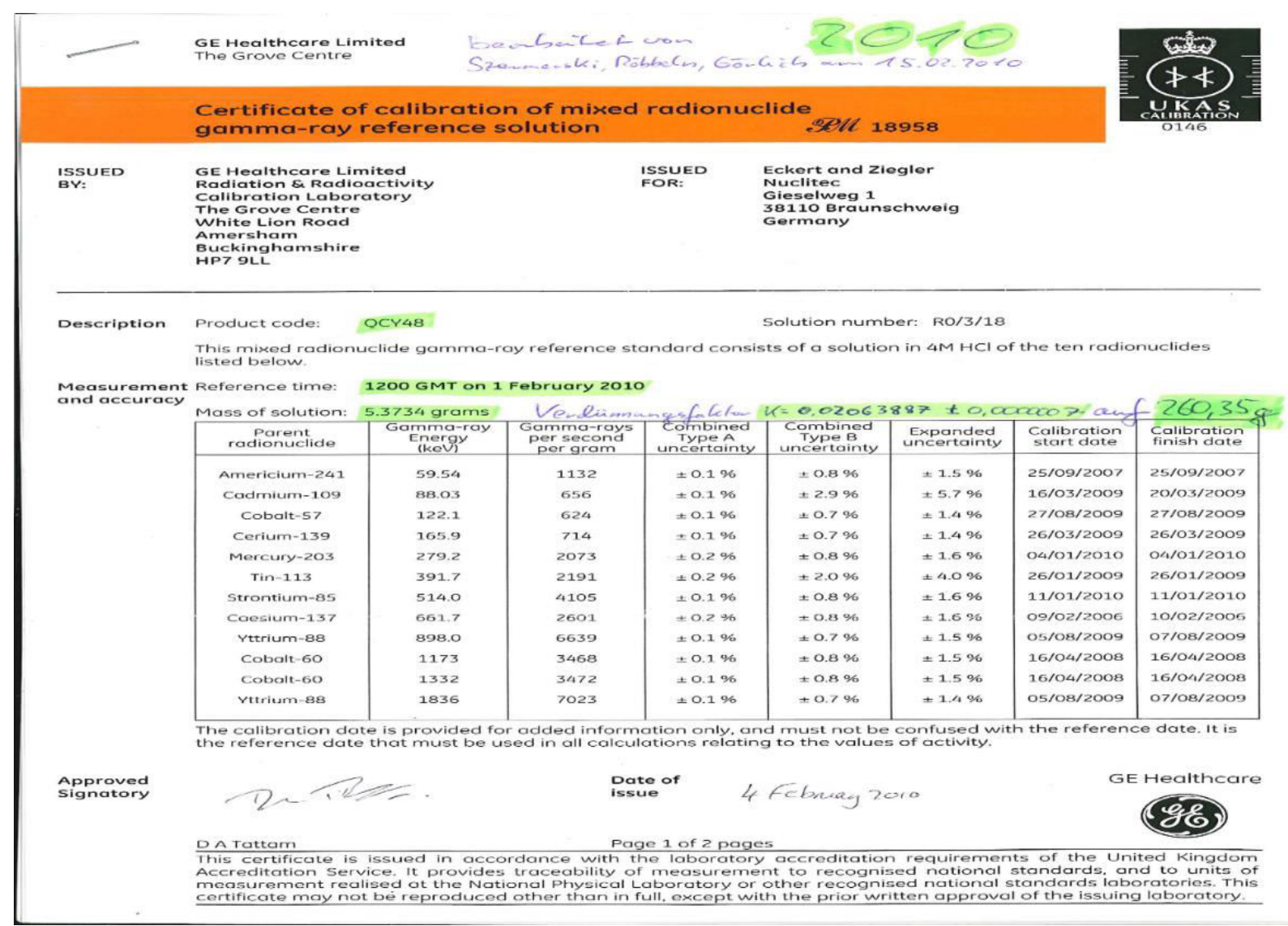


Annex 2

\begin{tabular}{|c|c|c|c|c|}
\hline \multicolumn{5}{|c|}{ Essential chemical parameters for AUWSSC } \\
\hline $\begin{array}{l}\text { Properties/Parame- } \\
\text { ters }\end{array}$ & $\begin{array}{l}\text { Standard values for Afghan- } \\
\text { istan }[\mathrm{mg} / \text { Litre }=\text { ppm }= \\
\mathrm{mg} / \mathrm{kg}]- \text { Maximum Permis- } \\
\text { sible }\end{array}$ & $\begin{array}{l}\text { WHO Guidelines as in } \\
\begin{array}{c}2011[\mathrm{mg} / \mathrm{Litre}=\mathrm{ppm} \\
=\mathrm{mg} / \mathrm{kg}]\end{array}\end{array}$ & $\begin{array}{c}\text { National Standard of } \\
\text { most Asian countries } \\
{[\mathrm{mg} / \mathrm{Litre}=\mathrm{ppm}=} \\
\mathrm{mg} / \mathrm{kg}]\end{array}$ & General Remarks \\
\hline Aluminium $(\mathrm{Al})$ & 0.2 & N/A & 0.2 & \\
\hline Antimony $(\mathrm{Sb})$ & 0.02 & 0.02 & 0.02 & \\
\hline Barium $(\mathrm{Ba})$ & 0.7 & 0.7 & 0.7 & \\
\hline Boron (B) & 2.4 & 2.4 & 2.4 & \\
\hline Cadmium $(\mathrm{Cd})$ & 0.003 & 0.003 & 0.003 & \\
\hline Chlorine $(\mathrm{Cl})$ & 250 & $\mathrm{~N} / \mathrm{A}$ & 250 & $\begin{array}{l}\text { Permissible limit in the absence of alter- } \\
\text { nate water source can rise up to } \\
1000 \mathrm{mg} / 1 \text {. }\end{array}$ \\
\hline Chromium (Cr) & 0.05 & 0.05 & 0.05 & \\
\hline Copper $(\mathrm{Cu})$ & 2 & 2 & 2 & \\
\hline Iron $(\mathrm{Fe})$ & 0.3 & $\mathrm{~N} / \mathrm{A}$ & 0.3 & \\
\hline Sodium $(\mathrm{Na})$ & 200 & $\mathrm{~N} / \mathrm{A}$ & 200 & \\
\hline Sulphate ( SO2-4) & 250 & N/A & 250 & $\begin{array}{l}\text { Permissible limit in the absence of alter- } \\
\text { nate water source can rise up to } 400 \mathrm{mg} / \mathrm{l} \text {. }\end{array}$ \\
\hline Magnesium (Mg) & 30 & N/A & 30 & $\begin{array}{l}\text { Permissible limit in the absence of alter- } \\
\text { nate water source can rise up to } 100 \mathrm{mg} / 1 \text {. }\end{array}$ \\
\hline
\end{tabular}




\begin{tabular}{|c|c|c|c|c|}
\hline Calcium $(\mathrm{Ca})$ & 75 & N/A & 75 & $\begin{array}{l}\text { Permissible limit in the absence of alter- } \\
\text { nate water source can rise up to } 200 \mathrm{mg} / 1\end{array}$ \\
\hline \multicolumn{5}{|l|}{ Cobalt (Co) } \\
\hline \multicolumn{5}{|l|}{ Mercury (Hg) } \\
\hline \multicolumn{5}{|c|}{ TOXIC CHEMICAL PARAMETERS } \\
\hline Cyanide (Cn) & 0.05 & $\mathrm{~N} / \mathrm{A}$ & 0.05 & \\
\hline Arsenic (As) & 0.05 & 0.01 & $0.01-0.05$ & \\
\hline Fluorine $(\mathrm{F})$ & 1.5 & 1.5 & 1.5 & \\
\hline Lead $(\mathrm{Pb})$ & 0.01 & 0.01 & 0.01 & \\
\hline Manganese (Mn) & 0.3 & $\mathrm{~N} / \mathrm{A}$ & 0.3 & \\
\hline Nickel (Ni) & 0.07 & 0.07 & 0.07 & \\
\hline Nitrate (NO3) & 50 & 50 & 50 & \\
\hline Nitrite (NO2) & 3 & 3 & 3 & \\
\hline Nitrate as Nitrogen & 11 & 11 & 11 & \\
\hline Selenium $(\mathrm{Se})$ & 0.04 & 0.04 & 0.04 & \\
\hline Zinc $(\mathrm{Zn})$ & 3 & N/A & 3 & \\
\hline
\end{tabular}


Annex 3

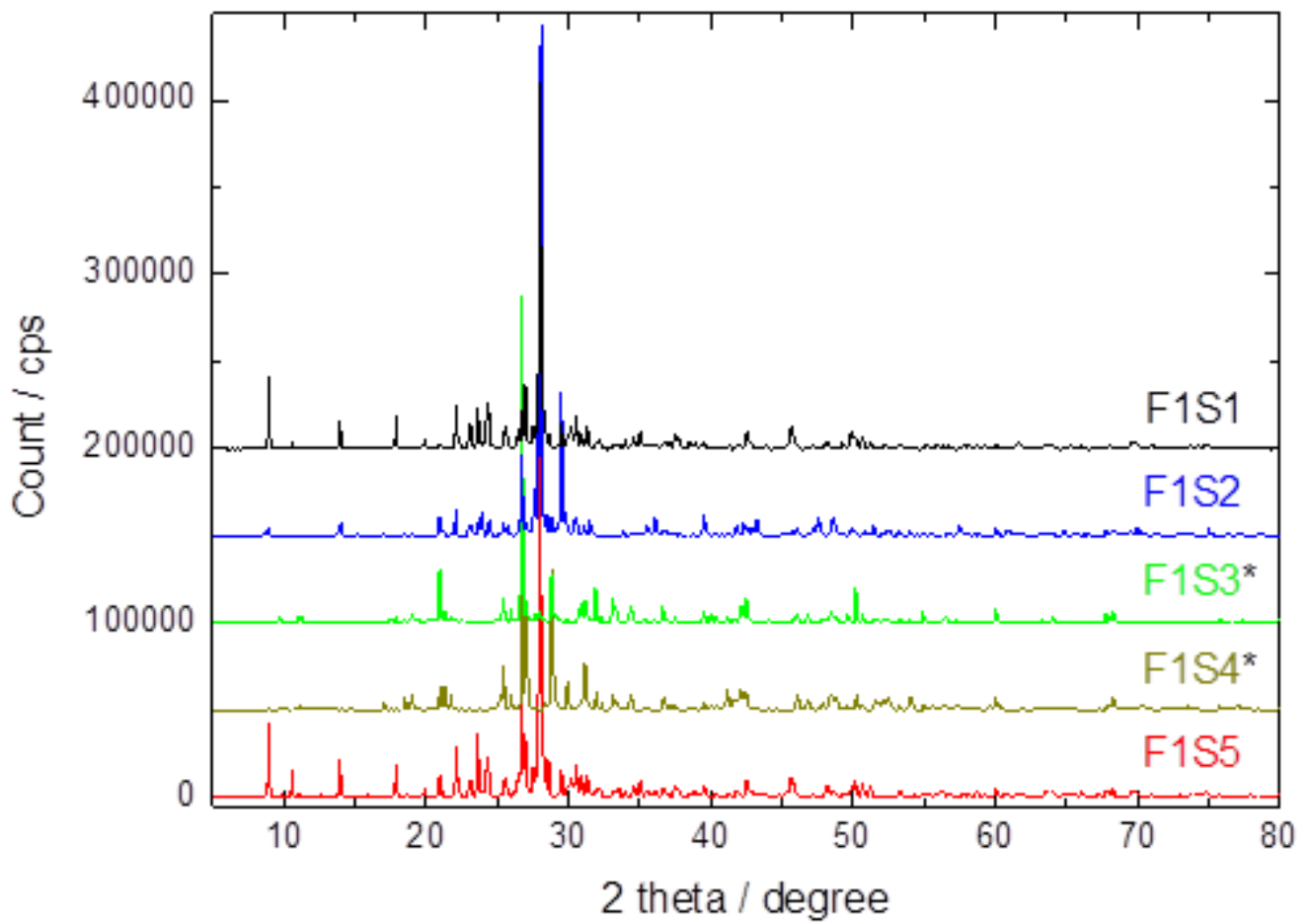

Figure1. Powder X-ray diffractograms for five samples of the F1 series. X-ray source: $\mathrm{Cu}$ Ka radiation. XRF detected a significant amount of thorium in these samples 


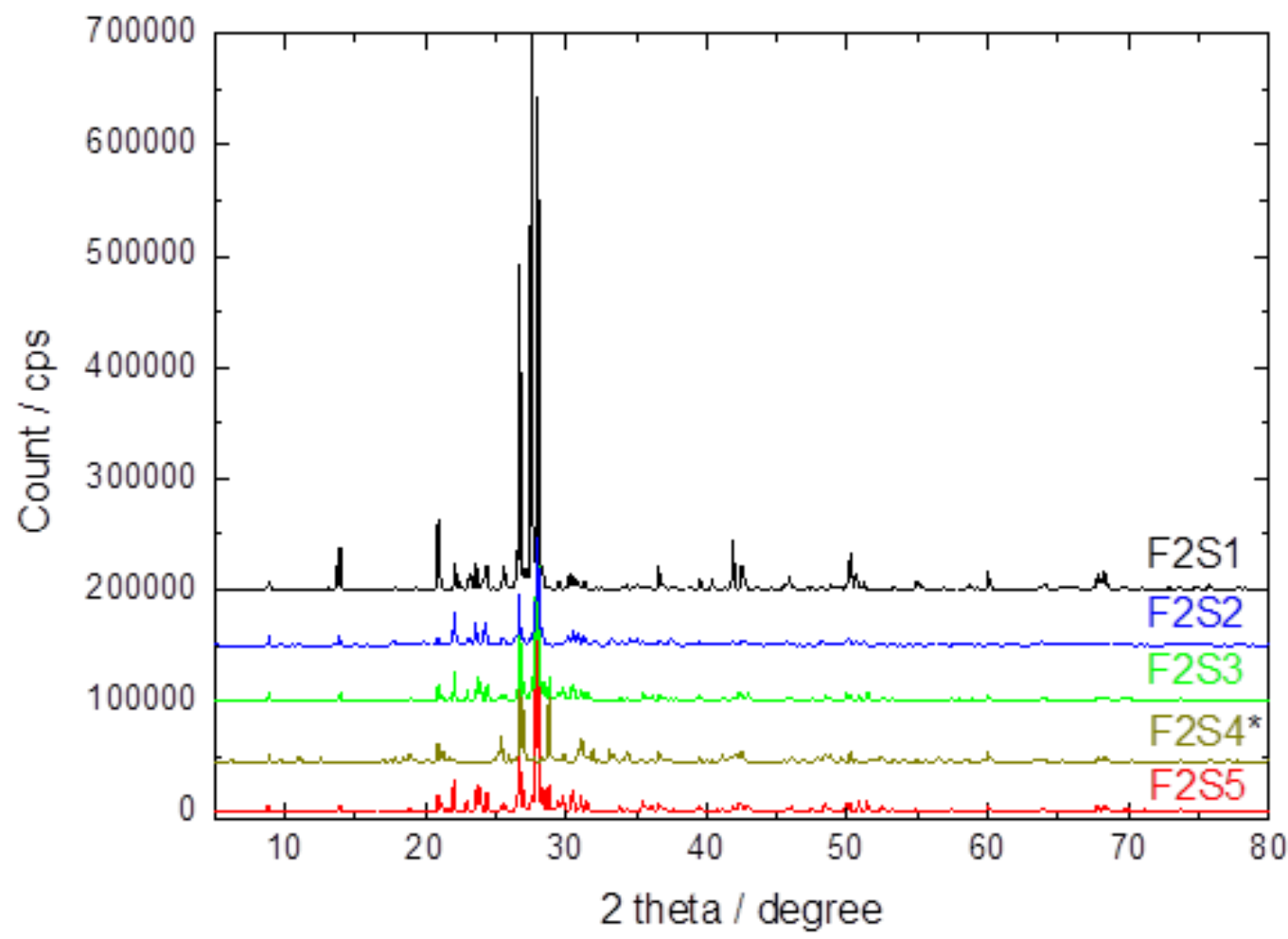

Figure2. Powder X-ray diffractograms for five samples of the F2 series. X-ray source: $\mathrm{Cu}$ Ka radiation. XRF detected a significant amount of thorium in this sample 


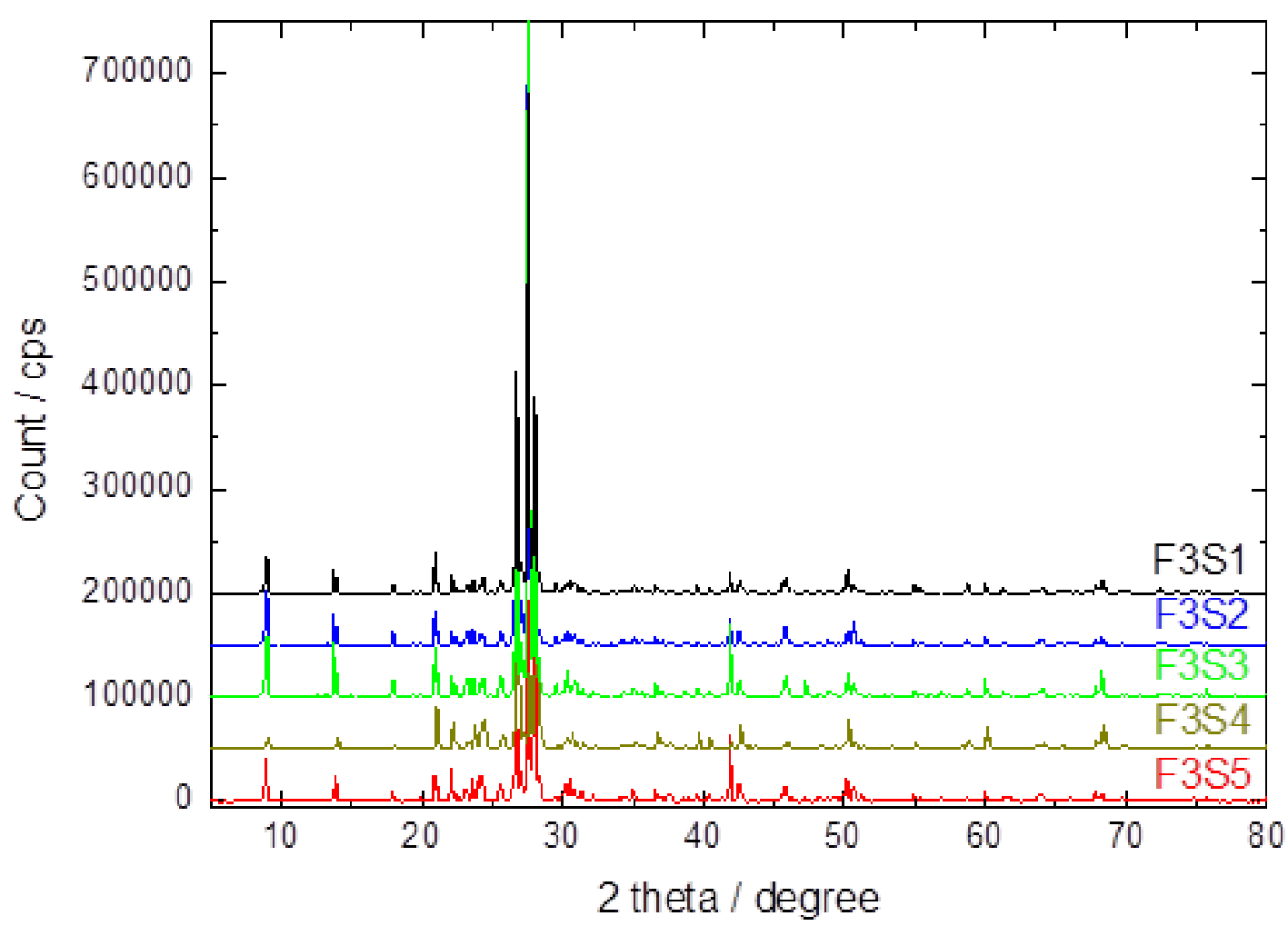

Figure3. Powder X-ray diffractograms for five samples of the F3 series. X-ray source: $\mathrm{Cu}$ K $\alpha$ radiation 